Report No. BMI-1125

Metallurgy and Ceramics

(TID-4500, 11 th Ed.)

Contract No. W-7405-eng-92

\title{
THE HEAT TREATMENT, TRANSFORMATION REACTIONS, AND MECHANICAL PROPERTIES OF SOME HIGH-STRENGTH ZIRCONIUM-BASE ALLOYS
}

by

Herbert A. Robinson

J. Robert Doig

Morris W. Mote

Paul D. Frost

August 9, 1956

BATTELLE MEMORIAL INSTITUTE

$505 \mathrm{King}$ Avenue

Columbus 1, Ohio 


\section{DISCLAIMER}

This report was prepared as an account of work sponsored by an agency of the United States Government. Neither the United States Government nor any agency Thereof, nor any of their employees, makes any warranty, express or implied, or assumes any legal liability or responsibility for the accuracy, completeness, or usefulness of any information, apparatus, product, or process disclosed, or represents that its use would not infringe privately owned rights. Reference herein to any specific commercial product, process, or service by trade name, trademark, manufacturer, or otherwise does not necessarily constitute or imply its endorsement, recommendation, or favoring by the United States Government or any agency thereof. The views and opinions of authors expressed herein do not necessarily state or reflect those of the United States Government or any agency thereof. 


\section{DISCLAIMER}

Portions of this document may be illegible in electronic image products. Images are produced from the best available original document. 
ABSTRACT

INTRODUCTION.

Heat Treatment of Titanium Alloys . • • • • • • • . • . • . . 2

Selection of Zirconium Alloys for Study. . . . . . . . . . . . . . 4

EXPERIMENTAL PROCEDURES . . . . . . . . . . . . . . . . . 4

Preparation of Materials . . . . . . . . . . . . . . . 6

Testing Procedures . . . . . . . . . . . . . . . . . . 7

RESULTS AND DISCUSSION OF HEAT-TREATMENT STUDY. . • • . 。

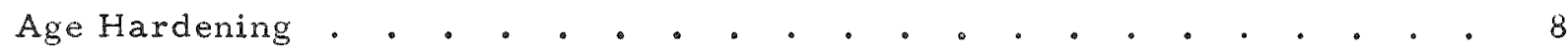

X-Ray Diffraction Analyses . . . . . . . . . . . . . . . . 16

Alloys Transforming by the Beta-Omega-Alpha Reaction . . . . . 21

Alloys Transforming by the Alpha Prime-Alpha Reaction . . . . . 26

Selection of Heat Treatments for the Evaluation of

Mechanical Properties . . . . . . . . . . . . . . . . . . 30

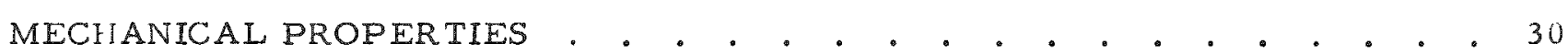

Room-Temperature Tensile Properties . . . . . . . . . . . . . 31

Alpha-Beta Alloys . . . . . . . . . . . . . . . . 31

Alpha Alloys . . . . . . . . . . . . . . . . . . . 33

Elevated-Temperature Tensile and Stress-Rupture Properties . . . . . 34

METALLOGRAPHIC EXAMINATION • • . . . . . . . . . . . . . 35

IN VESTIGA TION INTO THE EFFECTS OF HYDROGEN. . . . . . . . . . 39

Effect of Hydrogen on Tensile Properties . . . . . . . . . . . . to

The Effect of Hydrogen on the Microstructure. . . . . . . . . . . 41

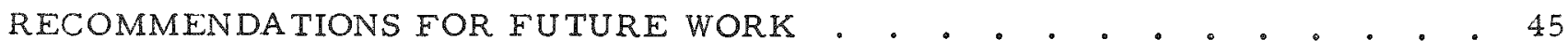

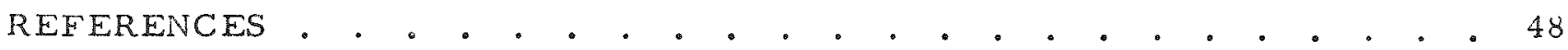

APPENDIX A

SUPPLEMENTARY AGE-HARDENING DATA • . . . . . . . . . . . . A-1

APPENDIX B

TABLES OF HEAT-TREATMENT AND MECHANICAL-PROPERTY DATA . . . B-1 


\title{
THE HEAT TREATMENT, TRANSFORMATION REACTIONS, AND MECHANICAL PROPERTIES OF SOME HIGH-STRENGTH ZIRCONIUM-BASE ALLOYS
}

\section{by}

\author{
Herbert A. Robinson, J. Robert Doig, Morris W. Mote, \\ and Paul D. Frost
}

\begin{abstract}
Zirconium alphabeta alloys were found to respond to solution and aging heat treatmenis very similarly to titanium alpha-beta alloys. A zirconium-5 w/o molybdenum-2 w/o tin alloy was heat treated to a 168,500-psi tensile strength and a 153,500-psi yield strength, with 11.5 per cent elongation in 1 in. In addition, a zirconium-5 w/o niobium-2 w/o tin alloy was heat treated to a 190,500-psi tensile and a 178,000. psi yield strength, with 2 per cent elongation. The transformations that occur upon aging these alloys may be represented as follows:
\end{abstract}

$$
\begin{aligned}
& \text { (1) } \beta \rightarrow \omega+\beta_{r} \rightarrow a+\beta_{u} \\
& \text { (2) } a^{\circ} \rightarrow a+\beta_{r}
\end{aligned}
$$

Preliminary elevated-temperature properties were very good. The zirconium- $5 w / 0$ molybdenum-2w/o tin alloy solution treated at $1525 \mathrm{~F}$ and aged $8 \mathrm{hr}$ at $1000 \mathrm{~F}$ was evaluated for tensile strength and $100-\mathrm{hr}$ rupture life at $840 \mathrm{~F}$. The tensile strength, yield strength, and elongation were $111,000 \mathrm{psi}, 84,500 \mathrm{psi}$, and 12 per cent, respectively. The 100-hr rupture strength was about 95,000 psi.

\section{INTRODUCTION}

Zirconium, because of its low thermal-neutron-absorption cross section and good corrosion resistance, has for some time been an important metal for use in thermal-neutron power reactors. When used as a cladding material for fuel elements, the Zircaloy alloys containing small amounts of tin are sufficiently strong. However, as reactor design technology progresses, it seems inevitable that a need for greater strength in a material of relatively low cross section will be desirable. There may be a need for such material in some homogeneous reactors, for example. For this reason, considerable research effort has been expended over the past several years toward developing zirconium alloys with greater strength both at room and at elevated temperatures. The research described in this report had such an objective.

Prior research on zirconium alloys had been concerned with development of greater strengths and creep resistance by solid-solution hardening or by dispersion hardening in an annealed condition. Such an approach would be expected to provide a material with properties that would not change 
upon long exposure to service temperatures up to the annealing temperature. However, the strength levels obtained were not high and the ductility of many of these materials was disappointingly low for the strengths obtained. Although solution and aging heat treatments had been applied to zirconium alloys, these had little success. Cuenching frequently produced low ductility. The possibility that the beta to omega transformation discovered recently in titanium alloys (1) might also take place in zirconium alloys and cause low ductility during hear treatment was, therefore, considered.

Zirconium and titanium are similar in many respects. They are both very reactive elements. They both are allotropic, exhibiting the bodycentered-cubic structure at elevated temperatures and the hexagonal at room temperatures. Their atoms are not too dissimilar in size, and they, therefore, form a continuous solid solution. Thus, it was conceivable that the same transformations produced in titanium alloys through heat treatment might also occur in zirconium.

Titanium has been studied extensively, and alloys have been developed as lightweight materials for aircraft structural applications. In the earliest experiments, the heat-treatment response of titanium was disappointing. As knowledge of the materials developed, however, it was found that a number of alloys responded very well to heat treatment and that roomtemperature strengths as high as $200,000 \mathrm{psi}$, with elongation values of 10 per cent(2), were entirely practicable. Further research has shown that materials so heat treated have superior strengths and, in many cases, adequate stability, at temperatures as high as $700 \mathrm{~F}$.

The present research on zirconium alloys was undertaken to determine if the proper selection of alloying materials and heat treatment could provide equally interesting improvements in the properties of zirconium-base alloys.

\section{Heat Treatment of Titanium Alloys}

The strengthening of titanium by heat treatment depends on the ability to quench and retain a metastable phase which subsequently can be transformed at aging temperatures to produce an alpha-beta microstructure. This "hardenability" is conferred on titanium by beta stabilizers, much as additions such as nickel, molybdenum, and vanadium confer hardenability on steels.

Two types of hardening reactions are recognized in titanium alloys, although the second type is not well understood. When enough beta

(1) References at end. 
stabilizer is present. it is possible to quench out a soft beta, which will harden upon aging. The final microstructure consists of a very finely dispersed alpha precipitate in an enriched-beta matrix; the strengthening effect results from the hardening of the beta matrix by this precipitate.

If the amount of beta stabilizer is somewhat less than that required to $r$ etain beta upon quenching, the quenched structure will be alpha prime (martensite), which is relatively soft and ductile. Aging will harden this structure also, but the hardening mechanism is more obscure. The alpha prime transforms to alpha of equilibrium composition with a rejection of a second phase which some investigators consider to be beta of equilibrium composition.

One other factor is of prime importance in titanium alloys: beta embrittlement. When titanium and titanium alloys are heated into the beta field, large beta grains develop very rapidly. In most alloys the resulting structure will have relatively low ductility, regardless of any subsequent heat treatment. Toughness and ductility can be restored only by sufficient hot work in the alpha-plus-beta field to produce a refined structure. The embrittlement is not caused entirely by the large beta grains, but is certainly influenced by their presence. Other undefined factors are probably more influential. The beta-embrittlement phenomenon has placed a restriction on heat-treatment procedures, since heat-treatment temperatures must not exceed the beta transus. Solution treatments, therefore, are conducted in the alpha-beta phase field, causing the final microstructure to always contain some primary alpha.

The heat-treatable titanium alloys all contain enough of one or more beta stabilizers to permit the quenching out of a metastable phase that will harden upon reheating to an intermediate temperature. Many of them also contain the alpha stabilizer, aluminum, for added strength. In practice, solution treatment is effected high in the alpha-beta-phase field, at temperatures between about 1350 and $1700 \mathrm{~F}$, depending on composition and the amount of aging response desired. Increasing the solution temperature (1) increases the amount of beta, (2) decreases the alloy content of the beta, (3) decreases the stability of the beta, and (4) increases the amount of the maximum aging response. Aging is conducted at temperatures between 800 and $1100 \mathrm{~F}$, approximately. The lower the temperature, the higher the maximum strength and the longer the time required to reach a given strength level. Because of the omega-embrittlement phenomenon, alloys that transform through omega must be aged past maximum hardness. How much overaging is necessary must be determined by experiment, using $\mathrm{X}-\mathrm{ray}$ diffraction to observe the disappearance of omega or tensile tests to determine when ductility is recovered. 
Selection of Zirconium Alloys for Study

In making a study aimed simultaneously at the development of an alloy and its heat treatment, it would be advantageous to make a thorough evaluation of the effects of composition in some arbitrarily selected conditions of heat treatment, and, subsequently, to investigate thoroughly the heat treatment of a few promising compositions. Time and funds were inadequate for such a thorough treatment. Rather it was decided to make as thorough an evaluation as possible of a few selected compositions.

Based on the understanding of titanium heat treatment, the requirement for a heat-treatable zirconium alloy is that it contain a certain minimum amount of one or more beta-stabilizing elements. In addition, strength will be enhanced by additions of alpha stabilizers. "Only molybdenum, niobium and tantalum, when present in sufficient amounts, are known to stabilize beta zirconium to room temperature during rapid cooling from the beta field. Tantalum was rejected because of its high thermal-neutron cross section. Aluminum and tin are both effective alpha stabilizers, but aluminum has been shown to seriously decrease the corrosion resistance of simple zirconium alloys in hot water. Therefore, for the present study tin was used as the alpha-stabilizer addition. In addition to major additions of molybdenum, niobium, and tin, minor additions of other elements were made in certain alloys for specific purposes.

The alloys selected for this evaluation are presented in Table 1, along with their analyses, beta-transus temperatures, and the temperatures at which they were rolled. The analyses indicated that intended compositions were usually realized. The molybdenum proved difficult to alloy homogeneously, probably because of incomplete solution during the melting operation.

\section{EXPERIMENTAL PROCEDURES}

All of the alloys were melted at Battelle and fabricated to sheet for heat treatment and evaluation. Generally, small specimens of each composition were solution treated at several different temperatures and aged at several temperatures for times as long as $1000 \mathrm{hr}$. The aged specimens were examined by hardness measurements and by $\mathrm{X}$-ray diffraction to correlate hardness with phases present after a given aging treatment. On the basis of the data so obtained, heat treatments were selected to apply to the remaining sheet for evaluation of tensile and stress-rupture properties. 
TABLE 1. COMPOSITION OF ALLOYS EVALUATED

\begin{tabular}{|c|c|c|c|c|c|c|c|c|c|c|c|c|c|c|c|}
\hline \multirow[b]{2}{*}{ Heat } & \multicolumn{6}{|c|}{$\begin{array}{l}\text { Nominal Composition } \\
\text { (Balance Zirconium), w/o }\end{array}$} & \multicolumn{7}{|c|}{ Analyses, w/o } & \multirow{2}{*}{$\begin{array}{c}\text { Beta-Transus } \\
\text { Temperature, } \\
\text { F }\end{array}$} & \multirow{2}{*}{$\begin{array}{c}\text { Rolling } \\
\text { Temperatux } \\
\text { F }\end{array}$} \\
\hline & $\mathrm{Sn}$ & $\mathrm{Mo}$ & $\mathrm{Nb}$ & $\mathrm{Cr}$ & $\mathrm{Ni}$ & Other & $\mathrm{Sn}$ & Mo & $\mathrm{Nb}$ & $c$ & $\mathrm{~N}$ & $O(a)$ & $H(a)$ & & \\
\hline$x-11$ & - & 5.5 & - & - & - & - & - & 5.5 & - & - & - & - & - & 1475 to 1500 & $\infty$ \\
\hline$T M=42$ & 4 & 2 & $\infty$ & - & - & - & 3.9 & 1.6 & - & - & - & - & - & 1735 to 1760 & - \\
\hline$A-2$ & 1.5 & - & - & 0.1 & 0.5 & $0.12 \mathrm{Fe}$ & - & 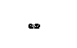 & - & - & - & - & - & $>1885$ & 1470 \\
\hline$A-3$ & 2 & 2 & - & - & - & - & - & - & $\infty$ & - & - & - & - & $>1885$ & 1470 \\
\hline$A-4$ & 2 & 5 & - & - & - & - & - & - & $\infty$ & - & - & - & - & $>1885$ & 1345 \\
\hline$A-6$ & 2 & - & 5 & - & - & - & 2.28 & - & 5.22 & 0.02 & 0.055 & 0.3290 & 0.0050 & $>1885$ & 1345 \\
\hline$A-8$ & 4 & 1 & - & 0.5 & 0.25 & - & $\infty$ & - & - & - & $\infty$ & - & - & $>1885$ & 1470 \\
\hline$B-1$ & 2 & 5 & $\infty$ & - & - & $\infty$ & - & - & - & - & - & - & - & 1645 to 1670 & 1350 \\
\hline$B-2$ & 2 & - & 5 & - & - & - & 2.23 & - & 5.25 & 0.01 & 0.006 & 0.1370 & 0.0037 & 1670 to 1695 & 1350 \\
\hline$C-49$ & 2 & 5 & - & - & - & - & - & - & - & - & - & 0.1140 & 0.0027 & 1625 to 1650 & 1500 \\
\hline
\end{tabular}

(a) Determined by vacuum ofusion analysis. 
Preparation of Materials

All of the alloys were prepared from sponge zirconium. Heats $X-11$ and TM-42 were prepared from high-quality sponge of an unknown grade designation. The $A, B$, and $C$ in the other heat designations refer to three different lots of Bureau of Mines Grade A sponge. Molybdenum was added as powder; niobium was added as powder to Heat A-6 and as pure sheet trimmings to Heat B-2. All other elements were added as high-purity metals.

The heats were melted in cold-mold arc furnaces; Heat $C-49$ was melted three times, all others twice. Heats $X-11$ and $T M-42$ were melted with the tungsten-tipped inert electrode, all others by the consumableelectrode technique. First melts were upset forged into consumable electrodes except in the cases of Heats $X-11$ and $T M-42$, which were rolled to sheet, sheared into clippings, and remelted by the tungsten-electrode technique. The final ingot was upset forged at 1650 or $1750 \mathrm{~F}$ to about $1 / 2-\mathrm{in}$. plate.

Samples were taken from the plate to determine the approximate betatransus temperature. Specimens were quenched after $1 / 2 \mathrm{hr}$ at temperatures about $25 \mathrm{~F}$ apart near the expected beta-transus temperature. The quenched specimens were examined under the microscope and the temperatures bracketing the beta transus were determined. All subsequent fabrication and heat treatments were confined to temperatures well below the beta transus.

The values found in this study are presented in Table 1. The alloys made from Lot A sponge all transformed completely to beta at some temperature above $1885 \mathrm{~F}$. This high transus temperature was probably caused by the high interstitial content, carbon, oxygen, and nitrogen, revealed in the analysis of Heat A-6. (Carbon, oxygen, and nitrogen, in order of increasing effect, are all alpha stabilizers and, therefore, raise the transition temperatures.) This effect of the interstitials was confirmed by doublemelting some of this sponge without additions. The beta transus of this unalloyed material was also above $1885 \mathrm{~F}$.

Rolling to 0.065 -in. sheet was accomplished in reductions of about 15 per cent per pass, with the stock being returned to the furnace between each pass. The muffle of the heating furnace was flushed continuously with helium to prevent excessive scaling and unnecessary loss of metal.

The rolled sheet was descaled by vapor blasting and the subscale metal which is contaminated by oxygen and nitrogen was removed by pickling off $0.002 \mathrm{in}$. from each surface. All pickling was carried out in an aqueous solution containing 45 per cent concentrated nitric acid and 5 per cent concentrated hydrofluoric acid. (Hydrogen contents of more than about 100 or 
$150 \mathrm{ppm}$ are known to have some very deleterious effects on the mechanical properties of titanium alloys, particularly in high strength conditions. Pickling can add significant quantities of hydrogen to titanium but it has been shown by several investigators that if the ratio of nitric acid to hydrofluoric acid content is maintained high enough, the hydrogen pickup will be negligible. Early in the work on zirconium alloys, the pickling solution used on the zirconium alloys was shown to produce negligible hydrogen pickup for alloys containing 80 to 90 ppm of hydrogen.)

After cleaning, sheet specimens for hardness and $X-r$ ay diffraction studies were sealed in evacuated Vycor capsules. The capsules were heated $1 \mathrm{hr}$ at the solution temperature and quenched into water or iced brine, the capsule being broken during the quench. These specimens were then vapor blasted and pickled again to remove about 0.0015 in. of metal from each side before aging. Most of the aging treatments were done in air. However, when the time at temperature was long enough to cause serious scaling, aging was carried out in evacuated Vycor capsules.

Tensile blanks were solution treated $1 / 2 \mathrm{hr}$ in air, cold-water quenched, and aged in air. They were then vapor blasted and machined to standard sheet specimens. After machining, they were pickled in the nitrichydrofluoric acid solution to remove about 0.002 in. from each surface of the specimens.

Testing Procedures

Haxdness determinations were made on a metallographically polished edge of the sheet specimens using a $10-\mathrm{kg}$ load on a square-pyramid diamond indentor. The Vickers hardness numbers obtained from these determinations are given in this report as the average of three values.

The tensile tests were conducted on a Baldwin-Southwark universal testing machine. The specimens were pulled at a crosshead speed of about 0.01 in. per min to the yield strength and then at 0.05 in. per min to fracture. The strain was measured with a loop-type extensometer. (3) With this instrument the extension of the specimen is converted to a corresponding deflection of a spring loop, which, in turn, is measured with SR-4 strain gages.

The X-ray diffraction patterns were obtained in small Debye cameras on rod samples. These were in the shape of phonograph needles, the tip of the needle being the portion examined. The needles were prepared by etching in a solution of $50 \mathrm{ml}$ of nitric acid, $150 \mathrm{ml}$ of water and approximately $10 \mathrm{ml}$ of hydrofluoric acid, the exact quantity being varied slightly for some samples to obtain a bright etch. 
Other experimental techniques used for specific phases of the investigation will be discussed in the specific sections of this report covering these results.

\section{RESULTS AND DISCUSSION OF HEAT-TREATMENT STUDY}

Following the course of aging reactions by means of hardness measurements is an expedient and inexpensive method that is entirely adequate for many systems for developing age-hardenable alloys. However, in the case of titanium, and, as it proved, of zirconium as well, it is necessary to suppliment hardness readings with $\mathrm{X}$-ray data. The reason is the presence, under some conditions, of the embrittling omega phase. When omega is present, hardness values are not directly related to other mechanical properties. The presence or absence of omega has only been determined by $\mathrm{X}-\mathrm{ray}$ diffraction.

Therefore, a rather complete $\mathrm{X}$-ray diffraction study had to be conducted before specific heat treatments could be selected for determination of mechanical properties. The age-hardening data were used first to select the conditions for X-ray diffraction analysis. Subsequently, both sets of data were used to select heat treatments for tensile and stress-rupture determinations.

\section{Age Hardening}

Extensive aging studies were made of the zirconium-5 w/o molybdenum $-2 \mathrm{w} / 0$ tin and zirconium $-5 \mathrm{w} / \mathrm{o}$ niobium $-2 \mathrm{w} / 0$ tin alloys. Earlier, the zirconium $-5.5 \mathrm{w} / 0$ molybdenum and zirconium $-4 \mathrm{w} / 0$ tin-2 $\mathrm{w} / 0$ molybdenum alloys were studied less extensively.

In general, the solution temperatures were varied between 1150 and $1785 \mathrm{~F}$, extending between the eutectoid temperature of the zirconiummolybdenum and zirconium-niobium binary systems $(4,5)$ shown in Figures 1 and 2, at the lower end, and the observed beta transus at the upper end. Aging temperatures ranged from 700 to $1200 \mathrm{~F}$ for the various alloys. Aging times were varied from 5 min to $1000 \mathrm{hr}$, depending upon the temperature of aging. In general, the short times were used for the higher aging temperatures and the long times for the lower aging temperatures.

All of the hardness data have been plotted as isothermal curves of hardness versus time. Figures 3 through 8 are representative curves for the alloys evaluated. Figures 3 through 6 represent the highest solution 
W'G IS XS

WRIEOIN-WRINODUIZ 'Z TURDIA

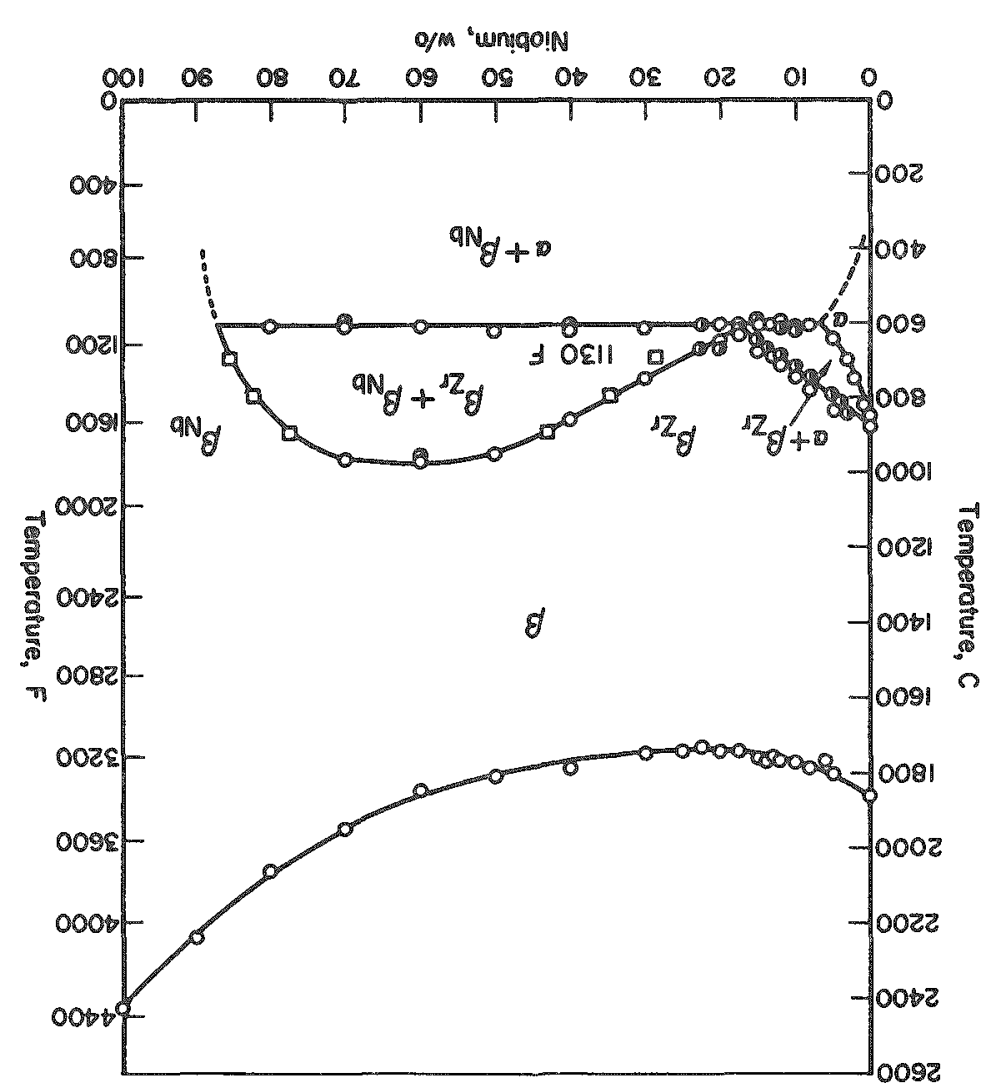

NGISAS

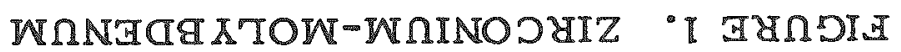

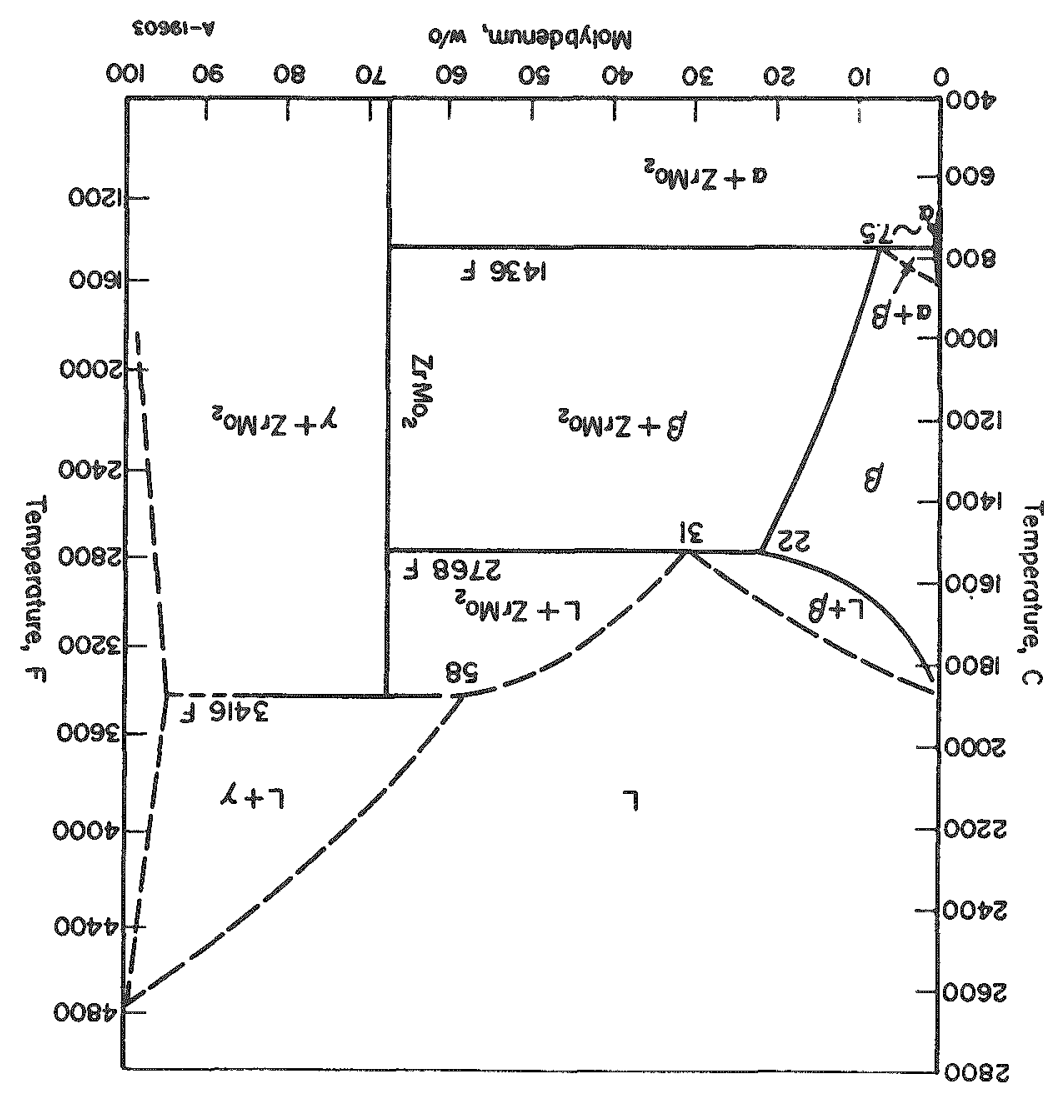




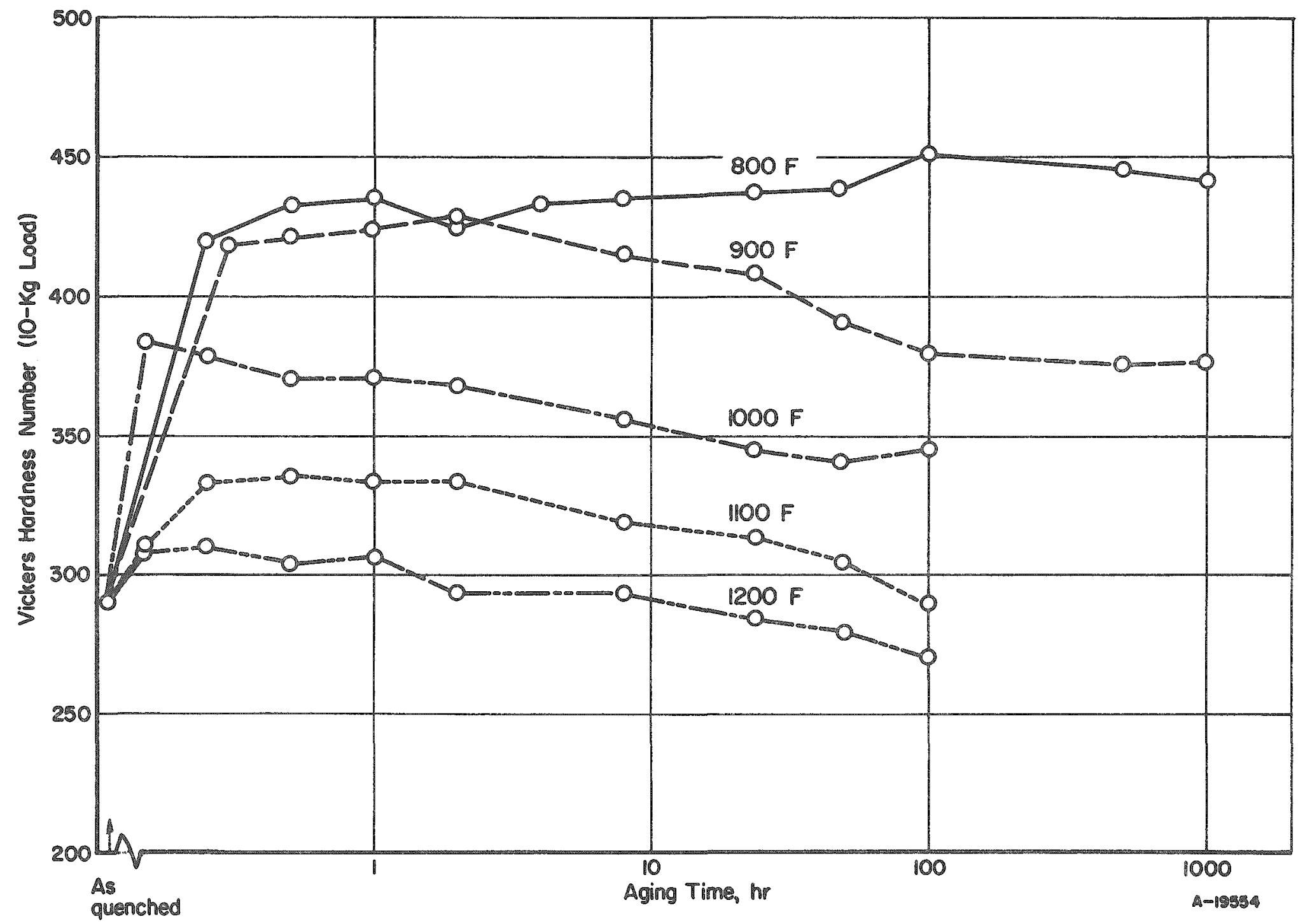

FIGURE 3. AGE-HARDENING CHARAC TERISTICS OF THE ZIRCONIUM-5 W/O MOLYBDENUM$2 \mathrm{w} / 0$ TIN ALLOY QUENCHED FROM $1600 \mathrm{~F}$

Aging temperatures as indicated. 


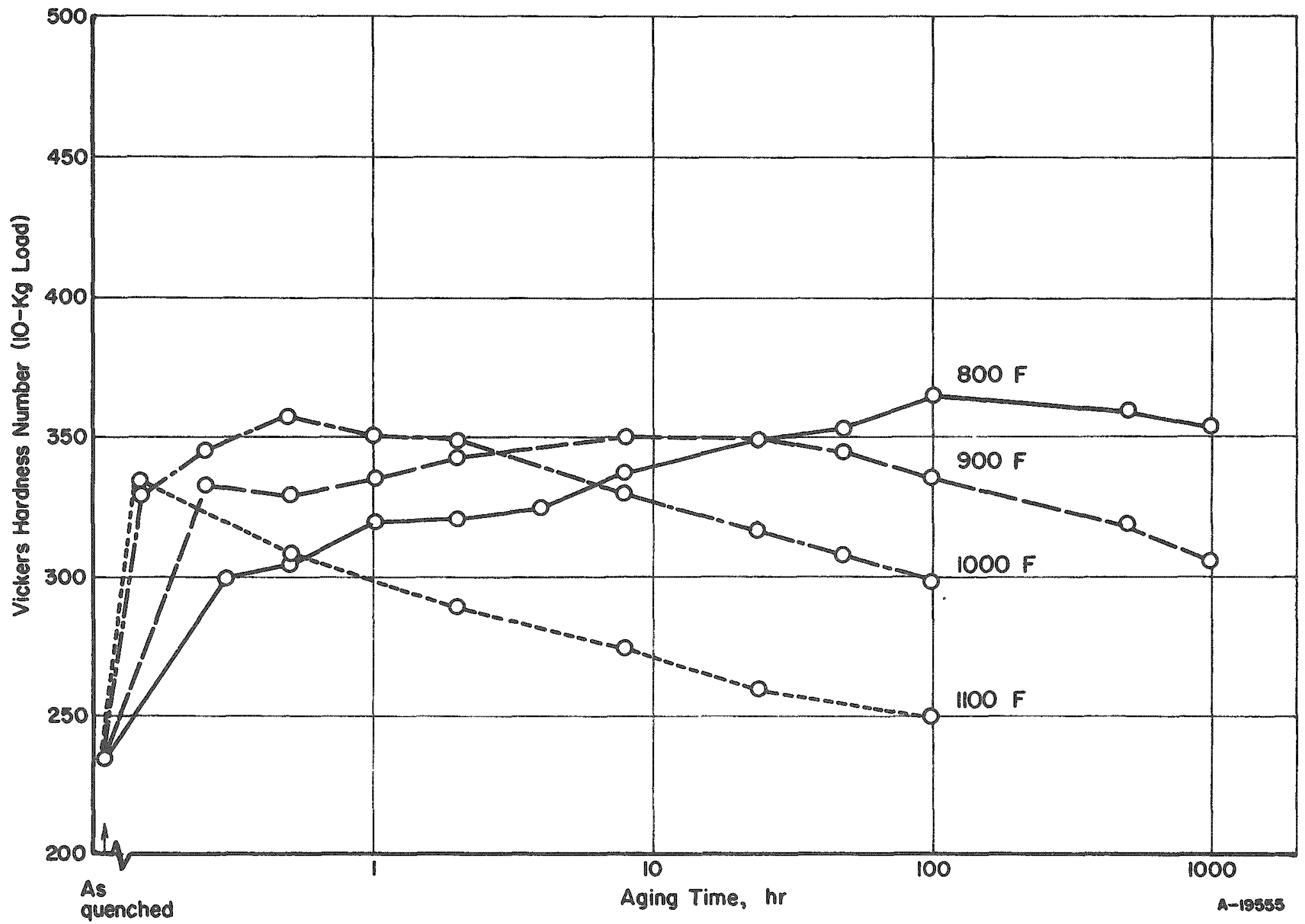

FIGURE 4. AGE-HARDENING CHARACTERISTICS OF THE ZIRCONIUM-5 w/O NIOBIUM2 w 10 TIN ALLOY QUENCHED FROM $1600 \mathrm{~F}$

Aging temperatures as indicated. 


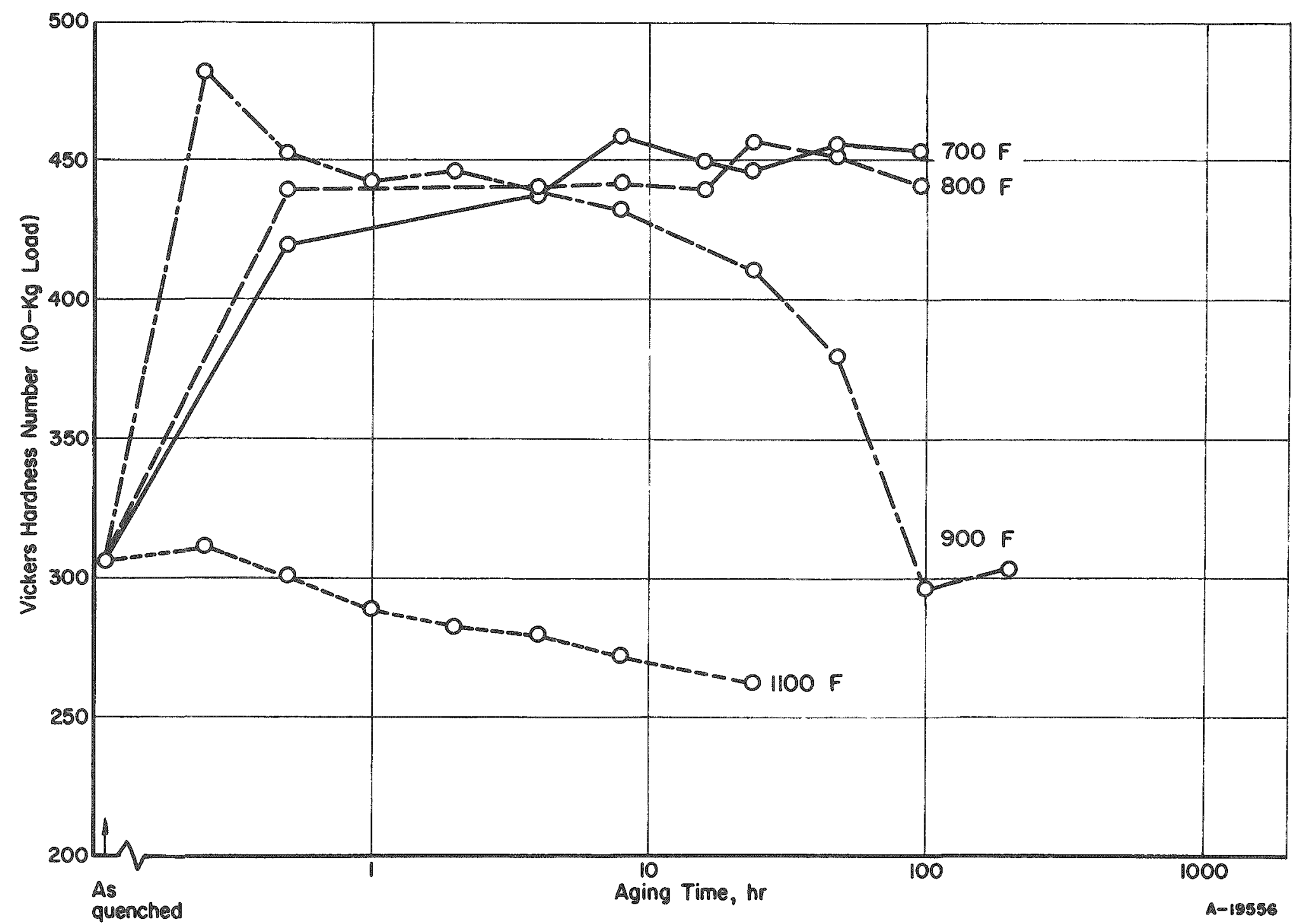

FIGURE 5. AGE-HARDENING CHARACTERISTICS OF THE ZIRCONIUM-5. 5 w/O MOLYBDENUM ALLOY QUENCHED FROM 1525 F

Aging temperatures as indicated. 


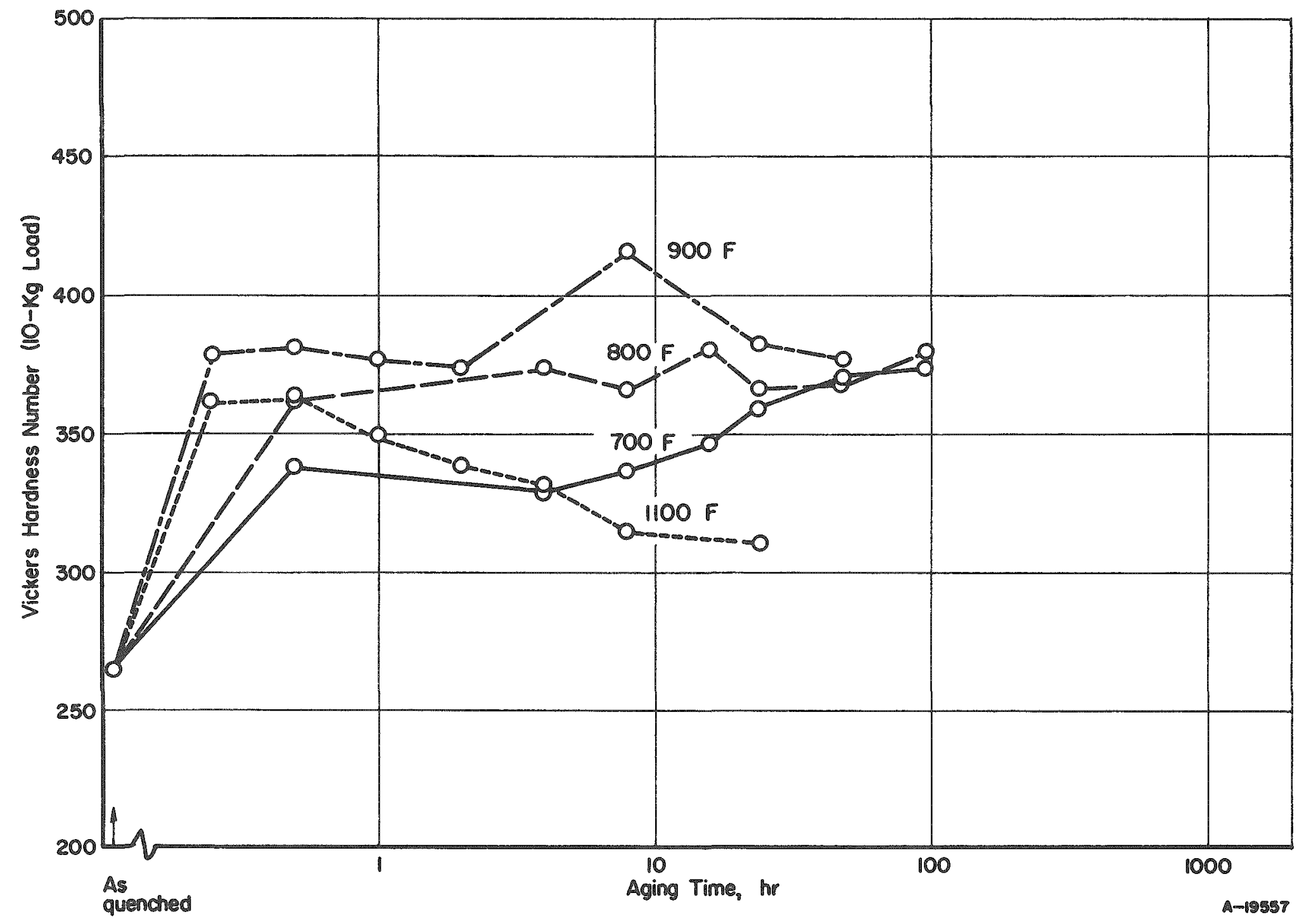

FIGURE 6. AGE-HARDENING CHARACTERISTICS OF THE ZIRCONIUM-4 w/o TIN-2 w/o MOLYBDENUM ALLOY QUENCHED FROM 1785 F

Aging temperatures as indicated. 


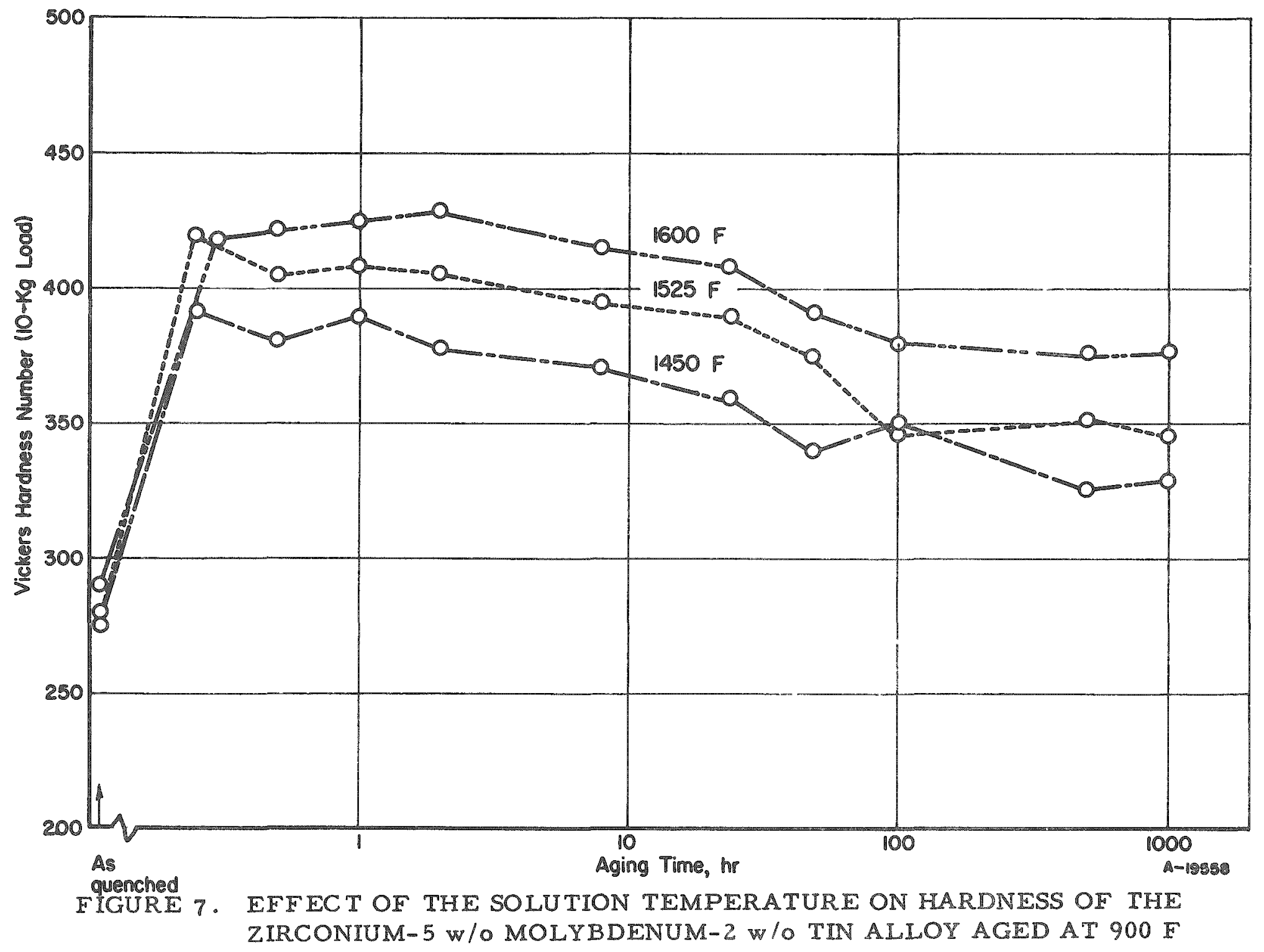




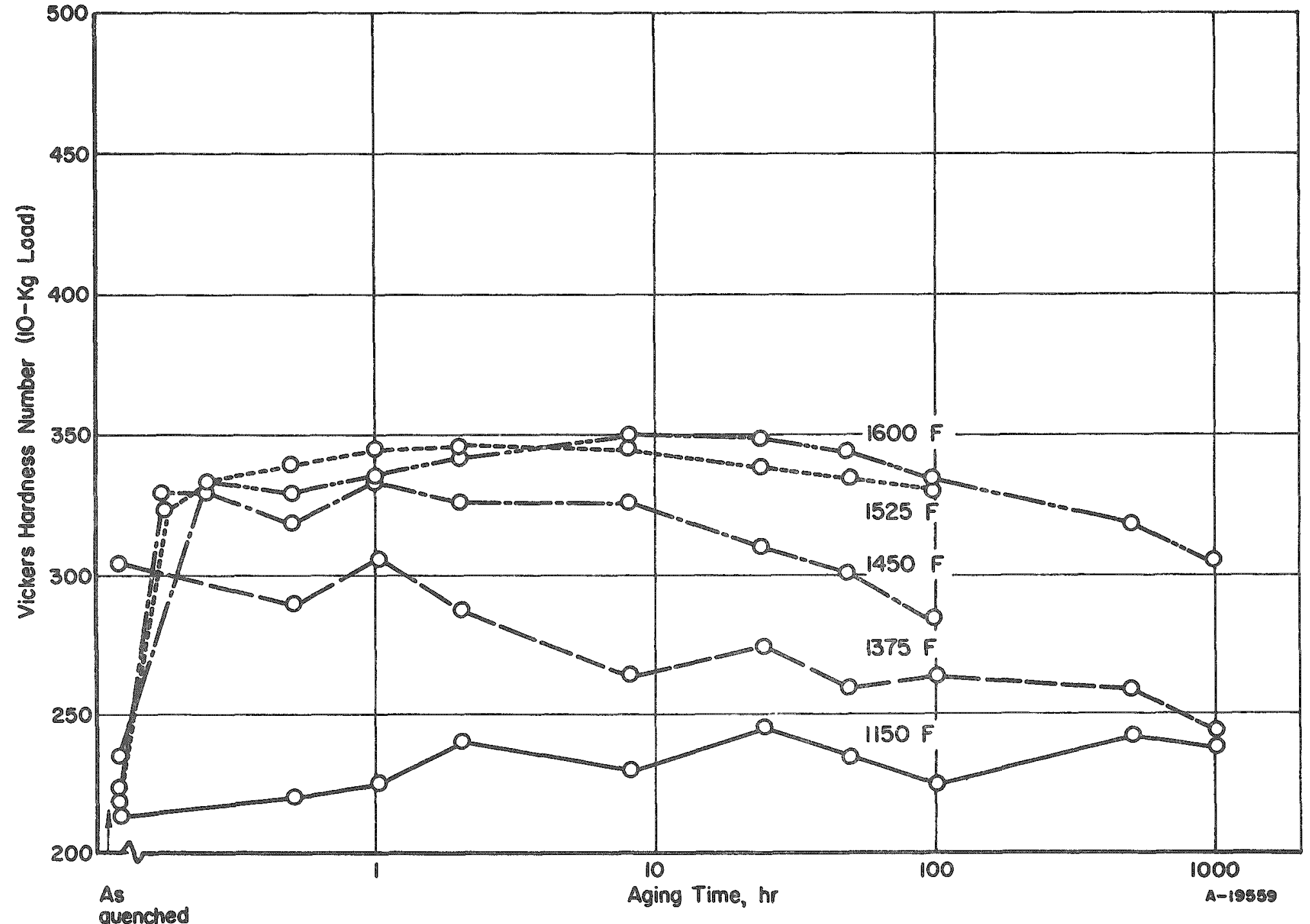

FIGURE 8. EFFECT OF SOLUTION TEMPERATURE ON HARDNESS OF THE ZIRCONIUM-5 w/O NIOBIUM-2 w/0 TIN ALLOY AGED AT $900 \mathrm{~F}$ 
temperature that was used for each of the four alloys described. The aging curves for the other solution temperatures are given in Figures $\mathbb{A}-1$ through A-8 in Appendix A.

The curves are typical of age-hardening curves. For a given solution temperature, aging at 700 or $800 \mathrm{~F}$ resulted in very little overaging, i.e., loss of hardness below the maximum values, at the maximum time of 1000 hr. Aging at 700,800 , or $900 \mathrm{~F}$ produced peak hardnesses; the higher the aging temperature, the shorter the time to attain the peak. Overaging occurred at $900 \mathrm{~F}$ and higher, and was quite marked in the zirconium-5.5 w/o molybdenum alloy. In this alloy, the hardness decreased from 480 VHN after $1 / 4 \mathrm{hr}$ of aging to about $300 \mathrm{VHN}$ after 100 and $200 \mathrm{hr}$. On the other hand, the hardness of the zirconium-5 w/o molybdenum-2 w/o tin alloy decreased only from 435 after $1 \mathrm{hr}$ to about 380 VHN after $100 \mathrm{hr}$. Thus, tin apparently retards the aging cycle of zirconium-molybdenum alloys.

A cross plotting of the hardness data has been made in Figures 7 and 8 to show the effect of solution temperature on aging behavior at $900 \mathrm{~F}$ for the zirconium-molybdenum-tin and zirconium-niobium-tin alloys, respectively. The curves exhibit aging behavior quite comparable to that of titanium alloys. Higher solution temperatures create a higher beta-toalpha ratio at the solution temperature, and specimens which have larger amounts of retained beta after quenching develop higher hardnesses during aging.

$\mathrm{X}$ - Ray Diffraction Analyses

In general, the aging of the zirconium alloys was found to be similar to that discovered earlier in titanium alloys. There appeared to be two mechanisms of aging, represented by the following equations:

$$
\begin{aligned}
& \begin{array}{l}
\beta_{0} \rightarrow \omega+\beta_{r} \rightarrow \beta_{u}+\alpha \rightarrow \alpha+ \\
\text { intermetallic compound or } \\
\text { terminal solid solution }
\end{array} \\
& \alpha^{\prime} \rightarrow \alpha+\beta_{\mathrm{u}} \text { or terminal solid solution, }
\end{aligned}
$$

where

$\beta_{0}=$ quenched or untransformed beta of original composition

$\beta_{\mathrm{r}}=$ beta partially enriched by omega or alpha formation

$\beta_{u}=$ fully enriched beta which approaches equilibrium composition

$\alpha=$ equilibrium alpha

$\alpha^{\circ}=$ martensitically formed alpha

$\omega=$ omega. 
These terms will be further defined in the paragraphs that follow.

The three types of beta are all cubic and differ only in concentration of solute, which causes a variation in the lattice parameter. The lattice parameters decrease in the order of $\beta_{0}$ to $\beta_{r}$ to $\beta u$ as the alloy content increases. The parameter of $\beta u$ approaches that of equilibrium beta according to the phase diagram, at the aging-temperature isotherm.

The alpha phase is a hexagonal equilibrium structure. Alpha prime is the martensitic transition structure that forms without diffusion from rapidly cooled beta. This phase is somewhat supersaturated in solute and therefore has a smaller lattice parameter than equilibrium alpha. The diffraction lines of alpha prime are usually rather diffuse because of distortion associated with its mode of transformation.

Omega is the designation given the intermediate transition phase that occurs when beta transforms to alpha at certain temperatures. It was observed for the first time in the work reported here. The name "omega" was taken directly from titanium-alloy technology because the phases appear to be analogous in mode of occurrence and are similar in their X-ray patterns.

The crystal structure of omega in a titanium-chromium alloy has been shown in work at Battelle $(6,7)$ to be complex cubic, with 52 titanium and 2 chromium atoms to the unit cell, somewhat similar to that of gamma brass. The unit-cell edge is about three times that of the parent beta phase. A hexagonal structure has been reported by Silcock, et al. (8), who studied a titanium-16 w/o vanadium alloy and interpreted the same $\mathrm{X}$-ray pattern differently. Omega has also been confirmed in other titanium alloys by Japanese and Russian investigators. $(9,10)$ Interplanar spacings of the omega phase obtained from $\mathrm{X}$-ray diffraction patterns of the zirconium-5. 5 w/o molybdenum alloy are shown in Table 2. These spacings are roughly 9 per cent greater than corresponding reflections in titanium alloys and are similar in their relative intensities. Because of limited funds, the crystal structure of the zirconium omega was not determined, but its structure is believed to be noncubic, as is suggested by the data in Table 2 . The observed interplanar spacings were compared with values calculated for a unit cell with an edge three times that of the parent beta, assuming the same intensities and Miller indexes that would occur in titanium omega. The differences between the interplanar spacings thus calculated and those observed were found to range erratically from 0.0 to 1.4 per cent. Yet, the error of film measurement for values below 1. $45 \mathrm{~A}$ (region of lowest instrumental errors) was found to be only 0.2 per cent or smaller. It must be concluded that the larger differences of 0.6 to 1.4 per cent are due to deviation from cubic symmetry, and that this new phase is not cubic in this aged condition. Likewise, the omega phase observed in samples of this alloy as quenched from the beta field was noncubic. 
IABLE 2. $X$-RAY POWDER DIFHRACTION PATTERN $(a)$ OF OMEGA PHASE IN AGED ZIRCONIUM $-5.5 \mathrm{w} / \mathrm{O}$ MOLYBDENUM ALLOY $(\mathrm{b})$

\begin{tabular}{|c|c|c|c|c|}
\hline $\begin{array}{c}\text { Visual } \\
\text { Intensity (c) } \\
\end{array}$ & Observed & $\begin{array}{l}\text { Spacings, A } \\
\text { Calculated on } \\
\text { Basis of } \\
a_{0}=10.66 \mathrm{~A}^{(\mathrm{d})}\end{array}$ & $\begin{array}{c}\mathrm{h}^{2}+\mathrm{k}^{2}+\mathrm{l}^{2} \text { Assumed } \\
\text { in Calculated } \\
\text { Spacings } \\
\end{array}$ & $\begin{array}{c}\text { Difference } \\
\text { Between Observed } \\
\text { and Calculated } \\
\text { Interplanar Spacings, } \\
\text { per cent }\end{array}$ \\
\hline $\mathrm{f}$ & 3.12 & 3.09 & 12 & +1.0 \\
\hline vvs & 2.50 & 2.52 & 18 & $=0.8$ \\
\hline $\mathrm{m}$ & 1.96 & 1.95 & 30 & +0.5 \\
\hline $\mathrm{ms}$ & 1.78 & 1.78 & 36 & 0.0 \\
\hline vvf & 1.65 & 1.65 & 42 & 0.0 \\
\hline mif & $1.56^{\circ}$ & 1.54 & 48 & +1.3 \\
\hline vs & 1.453 & 1.455 & 54 & -0.1 \\
\hline$s$ & 1.328 & 1.316 & 66 & +0.9 \\
\hline f & 1.317 & $-\infty$ & -- & $-\infty$ \\
\hline ms & 1.257 & 1.260 & 72 & -0.2 \\
\hline vs & 1.129 & 1.127 & 30 & +0.2 \\
\hline vs & 1.065 & 1.058 & 102 & +0.7 \\
\hline s & 1.029 & 1.029 & 108 & 0.0 \\
\hline $\mathrm{ms}$ & 1.015 & 1.001 & 114 & +1.4 \\
\hline vis & 0.982 & 0.976 & 120 & +0.6 \\
\hline
\end{tabular}

(a) Obtanted from etched rod sample in a 57.3-mm Debye camera, using filtered iron radiation.

(b) Solution treated $1 / 2 \mathrm{hr}$ at $1525 \mathrm{~F}$, quenched into iced brine and aged 4 s hr at $900 \mathrm{~F}$.

(c) $s=$ strong, $m=$ medium, $f=$ faint, $v=$ very。

(d) Assumed unit-cell edge three times the 3.564-A lattice constant of the beta phase. 
However, the omega phase did appear to be cubic in one sample of $a$ zirconium-5 w/o niobium-2 w/o tin alloy in the as-quenched condition after solution treating in the alpha-beta field at $1525 \mathrm{~F}$. X-ray diffraction data for this condition are shown in Table 3. It will be noted that the observed interplanar spacings of the omega phase having values below 1.4 A agreed within 0.2 per cent with those calculated for a cubic cell of $10.66 \mathrm{~A}$. After aging $48 \mathrm{hr}$ at $800 \mathrm{~F}$, the omega phase in this alloy showed a transformation to the noncubic form. The omega pattern gained added reflections at 1.015 and $0.982 \mathrm{~A}$, and the other interplanar spacings changed so that they agreed with the values of the noncubic omega in Table 2 .

Although the apparently cubic form of omega has been observed in only one sample, one may conclude that there is a driving force to produce either form. It might be expected that the mechanical properties could vary, depending on the form present, and this, in turn, might depend on alloy composition. It is not surprising that the cubic form of omega has been observed only in the as-quenched condition, since the phase might be held in cubic symmetry by the constraint imposed by coherency with the untransformed beta.

In addition to the phases that were identified, and represented in the reaction equations, a noncubic phase of very faint intensity was found in the molybdenum-bearing alloys aged more than $200 \mathrm{hr}$ at $900 \mathrm{~F}$. This phase appeared to be related to the enriched beta phase. The unidentified noncubic phase was represented by reflections at 1.70 and $1.67 \mathrm{~A}$, both paralleling the (200) reflection of enriched beta, and another reflection at $1.41 \mathrm{~A}$. These reflections together with the enriched beta reflections at 1.76 and 1.43 A might fit a tetragonal net, with axial ratio of $\mathrm{c} / \mathrm{a}=1.93$. The appearance of the noncubic phase at relatively long aging times but at times shorter than necessary for the appearance of $\mathrm{ZrMo}_{2}$, suggests that the unknown phase may be an ordered transition phase for the transformation of enriched beta to ZrMoz plus alpha.

The age-hardening curves for the alloys evaluated were quite similar but the $\mathrm{X}$-ray diffraction analyses indicated that the alloys could be divided according to the two types of transformations represented by the two reaction equations. The zirconium $-5 \mathrm{w} / 0$ molybdenum-2 $\mathrm{w} / 0$ tin alloy, the zirconium $-5.5 \mathrm{w} / \mathrm{o}$ molybdenum alloy and Heat $\mathrm{A}-6$ of the zirconium-5 w/o niobium-2 w/o tin alloy transformed by the beta-to-omega-to-alpha transformation. A second heat of the niobium alloy, Heat B-2, and the zirconium-4 w o tin-2 w/o molybdenum alloy transformed during aging by the alpha prime-to-alpha plus beta reaction. The X-ray diffraction results will be discussed separately according to the two types of reactions. 
TABLE 3. $X-R A Y$ DIFFRACTION POWDER PATTERN ${ }^{(a)}$ OF OMEGA PHASE IN AS-QUENCHED ZIRCONIUM-5 $w / O$ NIOBIUM -2 w/O TLN ALLOY

\begin{tabular}{|c|c|c|c|c|}
\hline $\begin{array}{c}\text { Visual } \\
\text { Intensity }(b) \\
\end{array}$ & Interpl: & $\begin{array}{l}\text { Calngs, } A \\
\text { Basilated of } \\
\text { Basis of } \\
a_{0}=10.66 \mathrm{~A}\end{array}$ & $\begin{array}{c}\mathrm{h}^{2}+\mathrm{k}^{2}+1^{2} \text { Assumed } \\
\text { in Calculated } \\
\text { Spacings } \\
\end{array}$ & $\begin{array}{c}\text { Difference } \\
\text { Between Observed } \\
\text { and Calculated } \\
\text { Interplanar Spacings, } \\
\text { per cent } \\
\end{array}$ \\
\hline $\mathrm{f}$ & 3.05 & 3.08 & 12 & -1.0 \\
\hline vvs & $2.49(\mathrm{c})$ & 2.51 & 18 & -0.8 \\
\hline $\mathrm{mf}$ & 1.94 & 1.95 & 30 & -0.5 \\
\hline$s$ & $1.77^{(c)}$ & 1.78 & 36 & -0.6 \\
\hline $\mathrm{mfd}$ & 1.54 & 1.54 & 48 & 0.0 \\
\hline vs & $1.444^{(c)}$ & 1.451 & 54 & -0.5 \\
\hline $\mathrm{m} v \mathrm{~d}$ & 1.315 & 1.312 & 66 & +0.2 \\
\hline$m s d$ & $1.254(c)$ & 1.256 & 72 & -0.2 \\
\hline m d & $1.124(\mathrm{c})$ & 1.124 & 90 & 0.0 \\
\hline $\mathrm{m} \mathrm{d}$ & 1.056 & 1.055 & 102 & +0.1 \\
\hline ms d & $1.026(\mathrm{c})$ & 1.026 & 108 & 0.0 \\
\hline
\end{tabular}

(a) Solution treated $1 / 2 \mathrm{hr}$ at $1525 \mathrm{~F}$ in the alpha-beta field. Alpha and untransformed beta were also present in the sample.

(b) $S=$ strong, $m=$ medium, $f=$ faint, $v=$ very, $d=$ diffuse.

(c) These reflections concide with reflections of untransformed beta which contribure strongly to the reported intensities. 
Alloys Transforming bv the Beta-Omega-

Alpha Reaction

The $\mathrm{X}$-ray diffraction analyses of the zirconium $-5.5 \mathrm{w} / \mathrm{o}$ molybdenum and the zirconium-5 w/o molybdenum- $2 \mathrm{w} / 0$ tin alloys confirmed the similarity of zirconium alloys and titanium alloys that retain beta on quenching. Phase identification by visual examination of diffraction patterns for both alloys after several heat treatments are given in Tables 4 and 5.

Figure 9 correlates the hardness changes and the phase changes observed during the aging of quenched specimens of the zirconium-5.5 w/o molybdenum alloy. In the quenched condition, the alloy consisted largely of retained beta, with some omega which had transformed from the beta during the quench. After aging $15 \mathrm{~min}$ at $900 \mathrm{~F}$, the hardness increased to over 450 VHN; simultaneously the intensity of the omega pattern increased, and part of the beta phase acquired a molybdenum content greater than the original $5.5 \mathrm{w} / \mathrm{o}$. The formation of this "partially enriched beta" is detected by broadening of the X-ray reflections of beta phase in the direction of increasing Bragg angle, and suggests that the zirconium omega phase, like that in titanium, has a relatively low solubility limit for betastabilizing elements. After $2 \mathrm{hr}$ at $900 \mathrm{~F}$, the omega pattern became more intense, while the beta of the original composition was no longer detectable with certainty. "Partially enriched beta" and a "fully enriched beta" existed at the same time. The latter was distinguished from the "original" and "partially enriched" beta by the appearance of a discrete Debye ring at the high-angle ends of the diffuse enriched-beta streaks. Hardness remained high (over $400 \mathrm{VHN}$ ) for about $30 \mathrm{hr}$. After $50 \mathrm{hr}$ at $900 \mathrm{~F}$, the alloy had overaged to a hardness level of 375 VHN and alpha had begun to form, although a strong omega pattern was still obtained. After $100 \mathrm{hr}$, the alloy had become quite soft, a strong alpha pattern was observed, the omega phase had almost disappeared, and the only beta present was highly enriched in molybdenum. With continued aging, the compound ZrMo2 began to form, omega completely disappeared, and fully enriched beta and alpha were present.

Figure 10 correlates the hardness changes and the phase changes observed during the aging at $900 \mathrm{~F}$ of specimens of the zirconium $-5 \mathrm{w} / \mathrm{O}$ molybdenum-2 w/o tin alloy (Heat $B-1$ ) quenched from $1600 \mathrm{~F}$. In the quenched condition this alloy contained primary alpha formed at the solutiontreatment temperature in addition to beta and omega. The structure was similar, except for an increase in the amount of alpha, when this alloy was quenched from 1525 and $1450 \mathrm{~F}$, as shown in Table 5 .

The phase changes during aging were very similar to those for the zirconium $-5.5 \mathrm{w} / \mathrm{o}$ molybdenum alloy up to about $100 \mathrm{hr}$ of aging time. The hardness, however, was somewhat lower for the zirconium-molybdenumtin alloy up to about $24 \mathrm{hr}$. Beyond this time the molybdenum alloy 
TABLE 4. PHASE IDENTIFCATION BY X-RAY DIFRACTION FOR SOLUTION-TREATED AND AGED SPECIMENS OF THE ZIRCONIUM5.5 W/O MOLYBDENUM(a) ALLOY

\begin{tabular}{|c|c|c|c|c|c|c|c|c|}
\hline & & \multicolumn{7}{|c|}{ Observed Intensities of Phase Pattems (c) } \\
\hline \multicolumn{2}{|c|}{ Aging Treatment ${ }^{(b)}$} & \multirow[b]{2}{*}{$\begin{array}{c}\text { Alpha, } \\
a \\
\end{array}$} & \multirow{2}{*}{$\begin{array}{c}\text { Untransformed } \\
\text { Beta. } \\
\beta_{0}\end{array}$} & \multirow{2}{*}{$\begin{array}{c}\text { Slightly } \\
\text { Enriched } \\
\text { Beta } \\
\beta_{r}\end{array}$} & \multirow{2}{*}{$\begin{array}{c}\text { Fully } \\
\text { Enriched } \\
\text { Beta } \\
\beta_{u}\end{array}$} & \multirow{2}{*}{$\begin{array}{c}\text { Unidentified } \\
\text { Noncubic } \\
\text { Phase }\end{array}$} & \multirow[b]{2}{*}{$\begin{array}{c}\text { Omega } \\
\omega\end{array}$} & \multirow[b]{2}{*}{$\mathrm{ZrMo}_{2}$} \\
\hline $\begin{array}{l}\text { Time, } \\
\text { hr }\end{array}$ & $\begin{array}{c}\text { Temperature, } \\
F\end{array}$ & & & & & & & \\
\hline \multicolumn{2}{|c|}{ As quenched } & 0 & vs & 0 & 0 & 0 & $\sim m f^{(d)} v d$ & 0 \\
\hline 96 & 700 & 0 & vs d & 0 & 0 & 0 & $s d$ & 0 \\
\hline $1 / 4$ & 900 & 0 & vs $\mathrm{d}$ & $f$ & 0 & 0 & $\mathrm{~m} \mathrm{~d}$ & 0 \\
\hline $1 / 2$ & 900 & 0 & vs $d$ & $\mathrm{mf}$ & 0 & 0 & $\mathrm{~ms} \mathrm{~d}$ & 0 \\
\hline 2 & 900 & 0 & vs & $\mathrm{m}$ & vf & 0 & s & 0 \\
\hline 48 & 900 & $\mathrm{f}$ & vs & $\mathrm{mf}$ & $\mathrm{mf}$ & 0 & $s$ & 0 \\
\hline 100 & 900 & s & 0 & 0 & $\mathrm{~m}$ & vvf & $\mathrm{vf}$ & 0 \\
\hline 200 & 900 & $s$ & 0 & 0 & $\mathrm{~m}$ & wf & 0 & vvf \\
\hline $1 / 4$ & 1100 & $m f$ & $0-m s d$ & $\mathrm{~m}$ & 0 & 0 & mf & 0 \\
\hline $1 / 2$ & 1100 & $\mathrm{~ms}$ & 0 & $\mathrm{~m}$ & $\mathfrak{f}$ & 0 & $\mathrm{mf}$ & 0 \\
\hline 1 & 1100 & $\mathrm{~s}$ & 0 & 0 & $s d$ & 0 & 0 & 0 \\
\hline 24 & 1100 & $s$ & 0 & 0 & $s$ & 0 & 0 & vvf \\
\hline
\end{tabular}

(a) Heat $X-11$.

(b) Solution treated 1 hour at $1525 \mathrm{~F}$ in evacuated Vycor capsules and quenched into cold water before aging.

(c) $s=$ strong, $\mathrm{rn}=$ medium, $\mathrm{f}=$ faint, $\mathrm{v}=$ very, $\mathrm{d}=$ diffuse.

(d) A very faint sharp reflection was observed at $2.18 \mathrm{~A}$. This reflection may be associated with an incipient form of omega, as this is a line position that should occur if omega was cubic. 
TABLE 5. PHASE IDENTIFICATION BY X-RAY DIFFRACTION FOR SOLUTION-TREATED AND AGED SPECIMENS OF THE ZIRCONIUM-5 W/O MOLYBDENUM-2 W/O TIN ALLOY

\begin{tabular}{|c|c|c|c|c|c|c|c|c|c|c|c|}
\hline \multirow[b]{3}{*}{ Heat } & \multirow{3}{*}{$\begin{array}{c}\text { Solution } \\
\text { Temperature(a) } \\
\mathrm{F}\end{array}$} & & & \multicolumn{8}{|c|}{ Observed Intensities of Phase Patterns (b) } \\
\hline & & \multicolumn{2}{|c|}{ Aging Treatment } & \multirow[b]{2}{*}{$\begin{array}{c}\text { Alpha, } \\
a \\
\end{array}$} & \multirow{2}{*}{$\begin{array}{c}\text { Untransformed } \\
\text { Beta, } \\
\beta_{0} \\
\end{array}$} & \multirow{2}{*}{$\begin{array}{c}\text { Partially } \\
\text { Enriched } \\
\text { Beta, } \\
\beta_{\mathrm{r}} \\
\end{array}$} & \multirow{2}{*}{$\begin{array}{c}\text { Fully } \\
\text { Enriched } \\
\text { Betas } \\
\beta_{u} \\
\end{array}$} & \multirow{2}{*}{$\begin{array}{c}\text { Unidentified } \\
\begin{array}{c}\text { Noncubic } \\
\text { Phase }\end{array} \\
\end{array}$} & \multirow[b]{2}{*}{$\begin{array}{c}\text { Omega, } \\
\omega \\
\end{array}$} & \multirow[b]{2}{*}{$\mathrm{ZxMO}_{2}$} & \multirow[b]{2}{*}{ Unknown } \\
\hline & & $\begin{array}{l}\text { Time, } \\
\mathrm{hr} \\
\end{array}$ & $\begin{array}{c}\text { Temperature, } \\
F \\
\end{array}$ & & & & & & & & \\
\hline$A-4$ & 1525 & $-\infty$ & $\cdots$ & ms & vs & 0 & 0 & 0 & 0 & 0 & vf \\
\hline$"$ & 1525 & 48 & 800 & $\mathrm{~m}$ & 0 & $0-\operatorname{mif}$ & $f-m$ & 0 & $\mathrm{~m} \mathrm{~d}$ & 0 & 0 \\
\hline$"$ & 1525 & 24 & 900 & $s$ & 0 & 0 & $n^{n} \mathrm{~m}$ & 0 & $\operatorname{mf}$ & vvf & $\vee v \varepsilon$ \\
\hline$"$ & 1525 & 4 & 1100 & 8 & 0 & 0 & $\mathrm{~m}$ & 0 & 0 & $v f$ & 0 \\
\hline$B-1$ & 1450 & 0 & -- & $\mathrm{m}$ & s & 0 & 0 & 0 & $\operatorname{wr}(\mathrm{c})$ & 0 & 0 \\
\hline$"$ & 1450 & 1. & 900 & $m f$ & Prevent & $\mathrm{m}-\mathrm{s} \mathrm{vd}$ & 0 & 0 & ms d & 0 & 0 \\
\hline$"$ & 1450 & 24 & 900 & $\mathrm{~m}$ & 0 & $\sim m f$ & $\sim \mathrm{m}$ vd & 0 & थII d & 0 & vvf \\
\hline$"$ & 1450 & 100 & 900 & 3 & 0 & 0 & $\mathrm{~m}$ & vvf & 0 & 0 & $v \vee f$ \\
\hline$"$ & 1525 & $-\infty$ & -- & $\mathrm{m} x$ & s & 0 & 0 & 0 & $v^{(c)}$ & 0 & 0 \\
\hline$"$ & 1525 & 48 & 900 & $\mathrm{~m}$ & 0 & 0 & $\mathrm{~ms} \mathrm{~d}$ & 0 & $v v f$ & 0 & 0 \\
\hline$n$ & 1525 & 100 & 900 & $\mathrm{~s}$ & 0 & 0 & ms d & $\mathrm{vf}$ & vvf & 0 & 0 \\
\hline$"$ & 1525 & 2 & 1000 & $\mathrm{~ms}$ & 0 & 0 & s & 0 & 0 & 0 & 0 \\
\hline$"$ & 1525 & 24 & 1000 & $\mathrm{~ms}$ & 0 & 0 & mas & 0 & 0 & 0 & 0 \\
\hline$"$ & 1525 & 100 & 1000 & $s$ & 0 & 0 & $\mathrm{~ms}$ & 0 & 0 & 0 & 0 \\
\hline$"$ & 1600 & - & -- & $f x$ & $s$ & 0 & 0 & 0 & $v(c)$ & 0 & 0 \\
\hline$"$ & 1600 & $1 / 4$ & 800 & $\operatorname{mf} x$ & s & $\sim f d$ & 0 & 0 & ms vd(c) & 0 & 0 \\
\hline$"$ & 1600 & 100 & 800 & $f x$ & 0 & $\mathrm{mbr}$ & Ins & 0 & $\mathrm{~s}$ & 0 & 0 \\
\hline$"$ & 1600 & 1000 & 800 & $f x$ & 0 & 0 & $m_{x}$ & 0 & $s$ & 0 & 0 \\
\hline$"$ & 1600 & $1 / 4$ & 900 & $f x$ & Present & $\sim \operatorname{mf} v d$ & 0 & 0 & $\operatorname{ms} d(c)$ & 0 & 0 \\
\hline$"$ & 1600 & 2 & 900 & $\mathrm{fx}$ & Present & nef br & $\mathrm{mf}$ & 0 & $s(c)$ & 0 & 0 \\
\hline " & 1600 & 24 & 900 & $f x$ & 0 & $\mathrm{fbr}$ & $\mathrm{ms}$ & 0 & $s \mathrm{~d}(\mathrm{c})$ & 0 & 0 \\
\hline$"$ & 1600 & 100 & 900 & s & 0 & 0 & $\mathrm{~m}$ & f & $t r$ & 0 & 0 \\
\hline$"$ & 1600 & 1000 & 900 & $s$ & 0 & 0 & $\mathrm{mf}$ & $\bar{f}$ & vví & 0 & 0 \\
\hline$"$ & 1600 & $1 / 12$ & 1000 & $f x$ & Rresent & $\leadsto \mathrm{rn} \mathrm{vd}$ & 0 & 0 & $m \mathrm{~d}^{(\mathrm{c})}$ & 0 & 0 \\
\hline$"$ & 1600 & 2 & 1000 & $s d$ & 0 & 0 & $\mathrm{~ms} \mathrm{~d}$ & थr & 0 & 0 & 0 \\
\hline$"$ & 1600 & 24 & 1000 & $\mathrm{~s}$ & 0 & 0 & $\mathrm{~ms}$ & 0 & 0 & 0 & 0 \\
\hline$"$ & 1600 & 100 & 1000 & $\mathrm{~s}$ & 0 & 0 & $\mathrm{~m} / \mathrm{s}$ & 0 & 0 & 0 & 0 \\
\hline$"$ & 1600 & $1 / 4$ & 1100 & $s$ & 0 & $\mathrm{mf}$ & s & 0 & 0 & 0 & 0 \\
\hline$"$ & 1600 & 2 & 1100 & $s$ & 0 & 0 & $\mathrm{~ms}$ & $?$ & 0 & 0 & 0 \\
\hline$"$ & 1600 & 100 & 1.100 & $s$ & 0 & 0 & $\mathrm{~ms}$ & 0 & 0 & $\mathrm{~m} f$ & 0 \\
\hline
\end{tabular}

(a) Heated $1 \mathrm{hr}$ in evacuated Vycor capsules and quenched in culd water.

(b) $s=$ strong, $m=$ medium, $f=$ faint, $t r=$ trace, $v=$ very, $d=$ diffuse, $b r=$ broad, $x=$ expanded.

(c) A weak diffraction lune was observed at 2.17 A for these specimens. This reflection may be associated with an incipient form of omega as this is a line position that should occur if omega was cubic. 


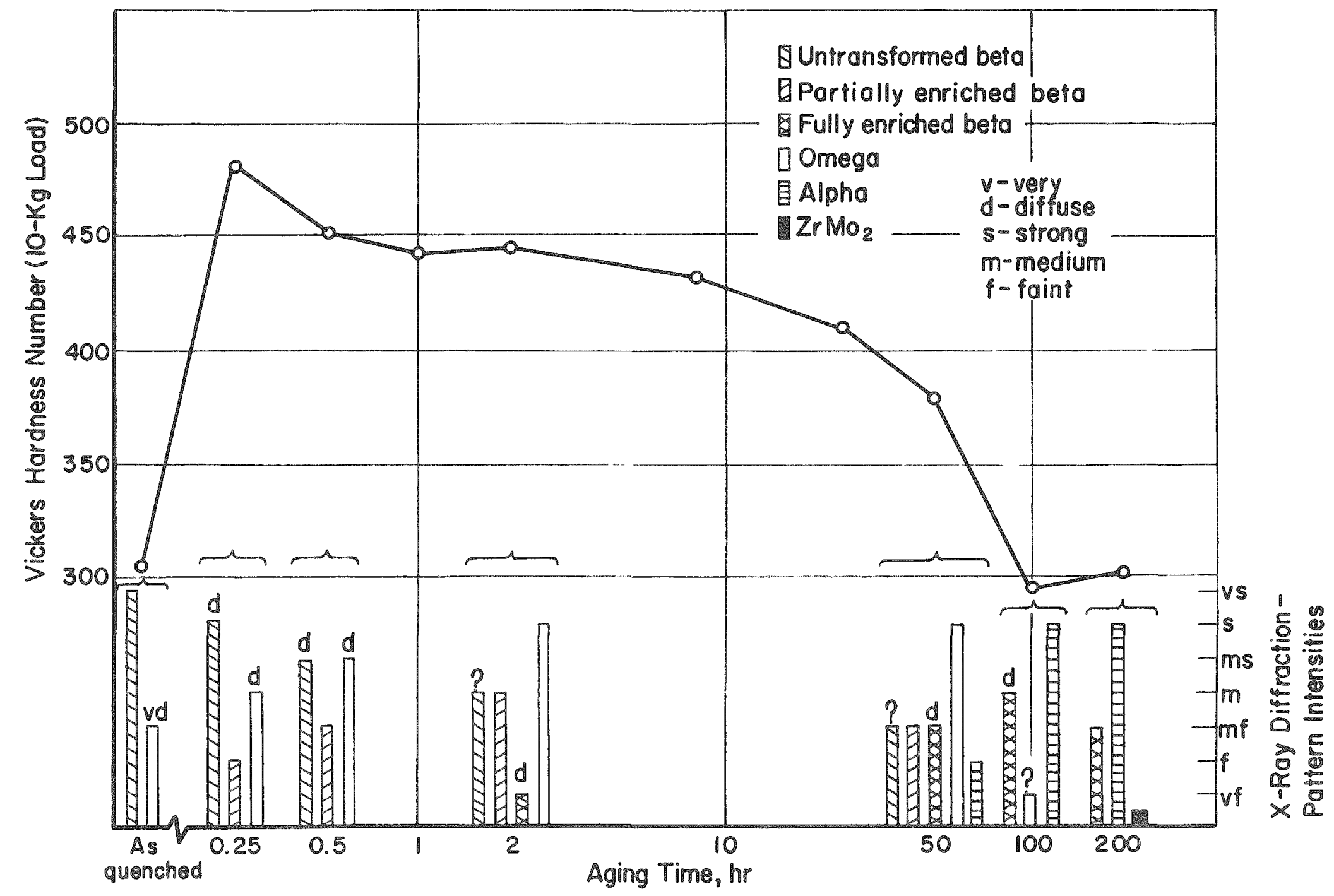

FIGURE 9. EFFECT OF AGING AT 900 F ON THE HARDNESS AND X-RAY DIFFRACTION-PATTERN INTENSITIES OF A ZIRCONIUM-5. 5 w/O MOLYBDENUM ALLOY QUENCHED FROM 1525 F 


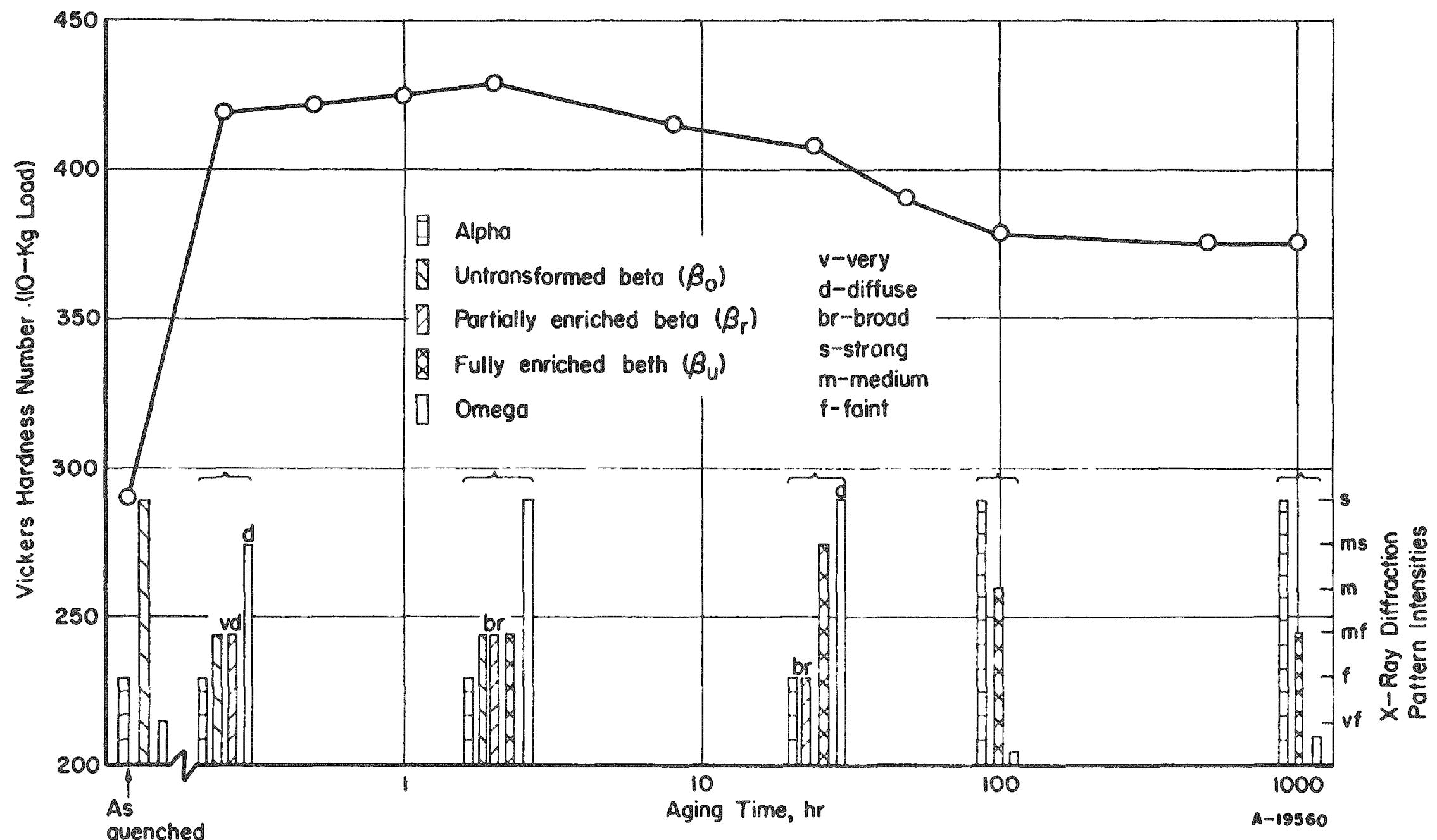

FIGURE 10. EFFECT OF AGING AT 900 F ON THE HARDNESS AND X-RAY DIFFRACTION-PATTERN INTENSITIES OF A ZIRCONIUM-5 w/0 MOLYBDENUM-2 w/0 TIN ALLOY QUENCHED FROM $1600 \mathrm{~F}$ 
decreased rapidly in hardness to about 300 VHN at $100 \mathrm{hr}$ of aging. The zirconium-molybdenum-tin alloy decreased only to 375 VHN and remained at this level up to $1000 \mathrm{hr}$ of aging. This suggests that alloys of this type, when heat treated by this method, might have good stability in elevatedtemperature applications.

The phase changes occurring at aging times of over $100 \mathrm{hr}$ differed for the two alloys. The $5.5 \mathrm{w} / 0$ molybdenum alloy had no omega, but did have compound present at $200 \mathrm{hr}$, whereas the zirconium-molybdenum-tin alloy (Heat $B-1$ ), which did not soften as much, still had a little omega present after $1000 \mathrm{hr}$. The latter alloy did have compound present, however, after aging $100 \mathrm{hr}$ at $1100 \mathrm{~F}$.

A second heat (Heat A-4) of the zirconium-molybdenum-tin alloy appeared to age more rapidly, as indicated by the appearance of compound after aging $24 \mathrm{hr}$ at $900 \mathrm{~F}$. This treatment produced a lower hardness, 364 VHN as compared with about 410 VHN for Heat B-1. The zirconium sponge used in Heat $A-4$ had a very high interstitial content, which probably contributed to the rapid aging of this heat (such an effect of interstitials has been observed in titanium alloys).

Alloys Transforming by the Alpha Prime-Alpha Reaction

This second type of aging reaction is not so well understood as the beta-omega-alpha reaction for titanium alloys. Of the commercial titanium alloys, only the titanium $-6 \mathrm{w} / 0$ aluminum $-4 \mathrm{w} / 0$ vanadium alloy, when quenched from high temperatures, is known to harden appreciably by this transformation. It has been observed, but not adequately described, in experimental titanium alloys. Unfortunately, neither time nor funds permitted a complete investigation of the zirconium alloys transforming in this way.

The zirconium $-5 \mathrm{w} / 0$ niobium $-2 \mathrm{w} / 0$ tin alloy and the zirconium -4 w/o tin-2 w/o molybdenum alloy will be considered in this category even though some omega was observed in one heat of the former alloy in one condition of heat treatment. The X-ray diffraction observations for the two niobium-tin heats are recorded in Table 6. Heat A-6 was quenched only from 1525 and aged at 800 and $900 \mathrm{~F}$. The as-quenched structure contained primary alpha (formed at the solution-treatment temperature) and omega. After aging $48 \mathrm{hr}$ at $800 \mathrm{~F}$, little if any change was observed in the $\mathrm{X}$-ray data, although some very significant increases in hardness were obtained. After aging $24 \mathrm{hr}$ at $900 \mathrm{~F}$, the omega had all disappeared and there was indication of the terminal niobium-zirconium solid-solution phase. This heat, quenched from $1525 \mathrm{~F}$ appeared to conform to the betato-omega-to-alpha concept of transformation. 
TABLE 6. PHASE IDENTIFICATION BY X-RAY DIFFRACTION FOR SOLUTION-TREATED AND AGED SPECIMENS OF THE ZRCONIUM-5 w/O NIOBIUM -2 w/O TIN ALLOY

\begin{tabular}{|c|c|c|c|c|c|c|c|c|}
\hline \multirow[b]{3}{*}{ Heat } & \multirow{3}{*}{$\begin{array}{c}\text { Solution } \\
\text { Temperature(a), } \\
F\end{array}$} & \multirow{2}{*}{\multicolumn{2}{|c|}{ Aging Treatment }} & \multicolumn{5}{|c|}{ Observed Intensities of Phase Patterns (b) } \\
\hline & & & & \multirow[b]{2}{*}{$\begin{array}{c}\text { Alpha, } \\
\alpha\end{array}$} & \multirow{2}{*}{$\begin{array}{l}\text { Alpha } \\
\text { Prime, } \\
a^{\prime}\end{array}$} & \multirow{2}{*}{$\begin{array}{c}\text { Untransformed } \\
\text { Beta }_{3} \\
\beta_{0} \\
\end{array}$} & \multirow[b]{2}{*}{$\begin{array}{c}\text { Omega } \\
\omega\end{array}$} & \multirow{2}{*}{$\begin{array}{c}\text { Niobium-Base } \\
\text { Teminal Solid } \\
\text { Solution }\end{array}$} \\
\hline & & $\begin{array}{l}\text { Time, } \\
\text { hr }\end{array}$ & $\begin{array}{c}\text { Temperature, } \\
F\end{array}$ & & & & & \\
\hline \multirow{3}{*}{$\begin{array}{l}\text { A } 6 \\
" \\
"\end{array}$} & 1525 & 0 & - & $s$ & 0 & 0 & $m d^{(c)}$ & 0 \\
\hline & 1525 & 48 & 800 & s & 0 & 0 & $\mathrm{~m} \mathrm{~d}$ & 0 \\
\hline & 1525 & 24 & 900 & $\mathrm{~s}$ & 0 & 0 & 0 & vfd \\
\hline \multirow{2}{*}{$\begin{array}{l}\text { B-2 } \\
" 1\end{array}$} & 1450 & 0 & $-\infty$ & $s$ & $\mathrm{~ms} \mathrm{kd}$ & $\mathrm{mf}$ & $0-f$ & 0 \\
\hline & 1450 & $1 / 4$ & 900 & $\int^{s} \mathrm{vd}$ & 0 & 0 & 0 & 0 \\
\hline$"$ & 1450 & 8 & 900 & $\left\{\begin{array}{l}s^{(\omega)} \\
\text { mf splc }\end{array}\right.$ & 0 & 0 & 0 & 0 \\
\hline$"$ & 1450 & 48 & 900 & ${ }_{s}(d)$ & 0 & 0 & 0 & $\mathrm{w} f+\mathrm{vc}$ \\
\hline$"$ & 1525 & 0 & $=-$ & $\mathrm{m}$ & m kvd & 0 & 0 & 0 \\
\hline$"$ & 1600 & 0 & -- & $s x$ & 0 & vvf & 0 & 0 \\
\hline$"$ & 1600 & 1 & 800 & ms $\mathrm{x}$ & ms kvd & 0 & 0 & 0 \\
\hline$"$ & 1600 & 48 & 800 & $\mathrm{~ms} \mathrm{~d}$ & $\mathrm{~ms} \mathrm{~d}$ & 0 & 0 & 0 \\
\hline$"$ & 1600 & 100 & 800 & $m s d$ & Ins vd & 0 & 0 & 0 \\
\hline$"$ & 1600 & $1 / 4$ & 900 & $\mathrm{~ms} \mathrm{x}$ & ms kvd & 0 & 0 & 0 \\
\hline$"$ & 1600 & 8 & 900 & $\cos _{(\mathrm{d})}^{\mathrm{mat}}$ & $\mathrm{ms}$ vd & 0 & 0 & 0 \\
\hline$"$ & 1600 & 38 & 900 & $\left\{\begin{array}{l}s^{\log } \\
\mathrm{m} \text { splc\&a }\end{array}\right.$ & 0 & 0 & 0 & 0 \\
\hline$"$ & 1600 & 1000 & 900 & $\mathrm{~s}$ & 0 & 0 & 0 & $f d$ \\
\hline$"$ & 1600 & $1 / 4$ & 1000 & $\mathrm{~ms}(\mathrm{e})$ & $\mathrm{ms}(\mathrm{e})$ & 0 & 0 & 0 \\
\hline$"$ & 1600 & $1 / 2$ & 1000 & $\mathrm{~ms}(\mathrm{e})$ & $\mathrm{ms}^{(\mathrm{e})}$ & 0 & 0 & 0 \\
\hline$"$ & 1600 & 24 & 1000 & $s d$ & 0 & 0 & 0 & vf $d$ \\
\hline
\end{tabular}

(a) Heated $1 \mathrm{hr}$ in evacuated Vycor capsules and quenched in cold water.

(b) $s=$ strong, $m=$ medium, $f=$ faint, $t r=$ trace, $v=$ very, $d=$ diffuse, $b r=$ broad, $x=$ expanded, $k=$ contracted, splc $=$ split $c-$ spacing.

(c) Omega in this sample fits a cubic ner.

(d) Diffuseness in background near (110) reflection may indicate strain, faulting, or possible compositional variation.

(e) Differentiation between alpha and alpha prime fails because the two a-spacings have approached almost to a common value. 
Heat $B-2$ was investigated more thoroughly and omega diffraction lines were not positively identified in any specimen. Alpha prime was observed in all as-quenched specimens save one. The metallographic examination indicated the presence of alpha prime even in that specimen (quenched from $1600 \mathrm{~F}$ ) although no $\mathrm{X}$-ray diffraction evidence for it was observed.

Aging at $800 \mathrm{~F}$ of specimens of Heat $\mathrm{B}-2$ quenched from $1600 \mathrm{~F}$ produced little change in the relative amounts of phases present, but did cause some adjustment in the composition of the phases, as indicated by changes in lattice dimensions. Hardnesses increased from 235 VHN as-quenched to 365 VHN maximum. Most of the hardening occurred very early in the aging cycle, with maximum values being reached sooner when aging was at higher temperatures.

The alpha prime disappeared after $48 \mathrm{hr}$ at $900 \mathrm{~F}$ and was indistinguishable from alpha after $1 / 4 \mathrm{hr}$ at $1000 \mathrm{~F}$. The niobium-base terminal solid solution appeared in material solution treated at $1600 \mathrm{~F}$ and then aged $1000 \mathrm{hr}$ at $900 \mathrm{~F}$ or $24 \mathrm{hr}$ at $1000 \mathrm{~F}$. Alpha prime formed during the quench from $1450 \mathrm{~F}$ disappeared after $1 / 4 \mathrm{hr}$ at $900 \mathrm{~F}$.

While no enriched beta was observed in these specimens, it is believed that this phase would form as alpha prime decomposes and prior to the formation of the niobium-rich solid solution. It is likely that the enriched beta was present after aging but was not detectable because of diffuseness of the pattern.

In comparing the two heats, there are some obvious differences in heat-treatment response. In Heat A-6 the beta formed during solution treatment at 1525 F transformed to omega during the quench. Further more, the completion of the transformation was relatively rapid. On the other hand, when Heat B-2 was solution treated at $1450 \mathrm{~F}$, only a questionable trace of omega was formed upon quenching and considerable alpha prime was formed. This is surprising because the lower solution treatment should have produced a more stable beta, which would be more likely to transform to omega than to alpha prime.

In an attempt to explain these observations a complete analysis of the two heats was made with the following results:

\begin{tabular}{|c|c|c|c|c|c|c|}
\hline \multirow[b]{2}{*}{ Heat } & \multicolumn{6}{|c|}{ Composition, w/o } \\
\hline & $\mathrm{Nb}$ & $\mathrm{Sn}$ & 0 & $\mathrm{~N}$ & C & $\mathrm{H}$ \\
\hline$A-6$ & 5.22 & 2.28 & 0.329 & 0.055 & 0.02 & 0.0050 \\
\hline$B-2$ & 5.25 & 2.23 & 0.137 & 0.006 & 0.01 & 0.0037 \\
\hline
\end{tabular}


The high oxygen, nitrogen, and carbon probably came from both the zirconium sponge and niobium powder used in Heat A-6. The high interstitials of Heat A-6 appear to have accelerated the decomposition of beta to omega. Interstitials have been shown to accelerate the beta-to-equilibrium alpha transformation in isothermal transformation of a titanium- $11 \mathrm{w} / 0$ molybdenum alloy. (11)

Table 7 presents the limited amount of $\mathrm{X}$-ray diffraction data obtained in the study of the zirconium-4 w/o tin-2 w/o molybdenum alloy. Because of the preliminary nature of the study made on this alloy, it was quenched from what was believed to be the beta field. The presence of primary alpha in the as-quenched structure suggests that the beta-transus determination was slightly in error or that some beta-to-alpha transformation occurred during the quench.

TABLE 7. PHASE IDENTIFICATION BY X-RAY DIFFRACTION FOR SOLUTION-TREATED AND AGED SPECIMENS OF THE ZIRCONIUM-4 $/ 0$ TIN-2 w/0 MOLYBDENUM ALLOY (2)

\begin{tabular}{|c|c|c|c|c|c|c|}
\hline & & \multicolumn{5}{|c|}{ Observed Intensities of Phase Patterns (c) } \\
\hline \multicolumn{2}{|c|}{ Aging Treatment(b) } & \multirow[b]{2}{*}{ Alpha } & \multirow{2}{*}{$\begin{array}{c}\text { Alpha } \\
\text { Prime, } \\
a^{\circ}\end{array}$} & \multirow{2}{*}{$\begin{array}{c}\text { Untransformed } \\
\text { Beta } \\
\text { Bo }\end{array}$} & \multirow{2}{*}{$\begin{array}{c}\text { Fully } \\
\text { Enriched } \\
\text { Beta } \\
\beta_{\mathrm{u}}\end{array}$} & \multirow[b]{2}{*}{ Omega } \\
\hline $\begin{array}{c}\text { Time, } \\
\mathrm{hr}\end{array}$ & $\begin{array}{c}\text { Temperature, } \\
F \\
\end{array}$ & & & & & \\
\hline \multicolumn{2}{|c|}{ As quenched } & ms d & md & 0 & 0 & 0 \\
\hline $1 / 4$ & 900 & ms & $\mathbf{m}$ & 0 & 0 & 0 \\
\hline $1 / 2$ & 900 & $\mathbb{s}$ & $\mathrm{ms}$ & 0 & 0 & 0 \\
\hline 8 & 900 & s & $\mathrm{ms} \mathrm{d}$ & 0 & 0 & 0 \\
\hline 48 & 900 & $s d$ & ms d & 0 & 0 & 0 \\
\hline 200 & 900 & $s d$ & $\mathrm{~ms} \mathrm{~d}$ & 0 & 0 & 0 \\
\hline $1 / 2$ & 1100 & $s d$ & 0 & 0 & $\mathrm{~m}$ & 0 \\
\hline
\end{tabular}

(a) Heat TM 42 .

(b) Solution treated 1 hour at $1785 \mathrm{~F}$ in evacuated Vycor capsules and quenched into cold water before aging. (c) $s=$ strong, $m \approx$ medium, $f=$ faint, $v=$ very, $d=$ diffuse, $s I=$ slightly.

No omega was found in this alloy and the data confirm the beta-toalpha prime-to-alpha transformation reaction. As aging continued at $900 \mathrm{~F}$, the alpha and alpha-prime lattice constants approached each other more and more closely, but this process was not quite complete even after $200 \mathrm{hr}$. At $1100 \mathrm{~F}$ the process was substantially complete in $1 / 2 \mathrm{hr}$. 


\section{Selection of Heat Treatments for the Evaluation of Mechanical Properties}

It was originally expected that the age-hardening curves, augmented by $X-r a y$ diffraction data would make it possible to select the one or two heat treatments that could be expected to produce maximum strength with adequate ductility. When the research program was planned, all evidence available suggested that overaging to complete the omega transformation would be necessary to avoid brittleness. Therefore, age-hardening curves were expected to indicate which heat treatments would produce overaging, and $X$-ray data were expected to show how far the overaging would have to be carried to completely transform the omega. (There was not sufficient time or money to demonstrate that omega did or did not cause embrittlement; it was assumed from the prior experience with titanium alloys that omega would embrittle zirconium alloys.)

However, the data obtained from the age-hardening curves and the earlier X-ray analyses did not permit complete interpretation of the heattreatment reactions. Because of the lack of time, heat treatments had to be selected from the data at hand. More complete X-ray data were obtained later.

Therefore, a rather thorough study of the effect of heat treatment on room-temperature tensile properties was made. The selection of a particular heat-treatment sequence was influenced by many factors. In general, however, the solution-treatment temperature was raised when it was desired to increase response during aging. The aging temperatures selected represent a compromise; the lower the temperature the greater the maximum effect, but the longer the time required to complete aging. Two other factors were also in control; solution treating was done at a temperature below the beta transus, and when omega was known to result from a treatment, aging was extended long enough to complete the beta-omega-alpha reaction. However, in many instances tensile determinations were made on material aged for shorter times as well so that some specimens contained significant quantities of omega. These were invariably accompanied by other specimens that had aged long enough to complete the reaction.

\section{MECHANICAL PROPERTIES}

It is general practice in any alloy-development work to make the original screening evaluations on the basis of room-temperature tensile properties. Promising compositions are subsequently evaluated with 
Iespect to other properties of partirnlar interest. Because of thc cnvisioned application of zirconium alloys, elevated-temperature strengths and stress-rupture values were obtained on material found to be of interest on the basis of room-temperature tensile properties.

\section{Room-Temperature Tensile Properties}

All of the tensile-property determinations are presented in Tables B-1 and B-2 in Appendix B. The alloys so presented are considered in two groups, the alpha-beta alloys and the alpha alloys. The alloys containing $5 \mathrm{w} / \mathrm{o}$ or more of molybdenum or niobium are considered alpha-beta alloys because that amount of beta stabilizer provided sufficient beta stability during the quench to promote good aging response.

\section{Alpha-Beta Alloys}

Early in this investigation ultimate tensile strengths as high as $200,000 \mathrm{psi}$ were obtained in both the zirconium-5 w/0 molybdenum-2 w/o tin and the zirconium $-5 \mathrm{w} / 0$ niobium $-2 \mathrm{w} / 0$ tin alloys. The elongation values were distressingly low and subsequent work had as its objective the improvement in elongation without too much loss in strength. The best results obtained to date are as follows:

\begin{tabular}{|c|c|c|c|c|c|c|}
\hline $\begin{array}{c}\text { Alloy Composition } \\
\text { (Balance Zirconium) } \\
\text { w/o }\end{array}$ & $\begin{array}{c}\text { Solution } \\
\text { Temperature, } \\
\text { F }\end{array}$ & $\begin{array}{c}\text { Aging } \\
\text { Temperature, } \\
\text { F }\end{array}$ & $\begin{array}{l}\text { Aging } \\
\text { Time, } \\
\text { hr }\end{array}$ & $\begin{array}{l}\text { Elongation } \\
\text { in } 1 \text { In. } \\
\text { per cent }\end{array}$ & $\begin{array}{l}0.2 \text { Per Cent } \\
\text { Offset Yield } \\
\text { Strength. psi }\end{array}$ & $\begin{array}{c}\text { Ultimate } \\
\text { Strength, } \\
\text { psi }\end{array}$ \\
\hline $5 \mathrm{Mo}-2 \mathrm{Sn}$ & 1525 & 900 & 48 & 11.5 & 153,500 & 168.500 \\
\hline $5 \mathrm{Nb}-2 \mathrm{Sn}$ & 1525 & 1000 & 8 & 10 & 133,000 & 153,000 \\
\hline $5 \mathrm{Nb}-2 \mathrm{Sn}$ & 1525 & 1100 & 24 & 16 & 96,000 & 112,500 \\
\hline $5 \mathrm{Nb}-2 \mathrm{Sn}$ & 1600 & 900 & 8 & 2 & 178.000 & 190,500 \\
\hline $5 \mathrm{Nb}-2 \mathrm{Sn}$ & 1600 & 1000 & 8 & 14 & 153,000 & 168,000 \\
\hline
\end{tabular}

The values are somewhat short of the 200, 000-psi ultimate strength-10 per cent elongation combination that has been obtained for titanium alloys and was the goal in this work. However, they represent a substantial improvement over previous zirconium-base alloys. There is every reason to expect that when sufficient study has been made to clarify the understanding of the complex aging reactions observed, a more desirable combination of alloy composition and heat treatment may be developed to the end that the goal may be achieved.

To better understand the effects of heat treatment on mechanical properties, the factors of solution-treatment temperature, aging temperature, and aging time will be considered separately. 
Effect of Solution-Treatment Temperature. Raising the solutiontreatment temperature does two related things. It increases the amount of beta-phase present at the solution-treatment temperature, but it simultaneously decreases the stability of the beta because it decreases the alloy content in the beta. The result is usually an increase in the degree of response upon subsequent aging.

The effect is illustrated with the following values obtained on the zirconium $-5 \mathrm{w} / 0$ niobium-2 $\mathrm{w} / 0$ tin alloy, Heat $\mathrm{B}-2$, as solution treated and as aged $8 \mathrm{hr}$ at $900 \mathrm{~F}$.

\begin{tabular}{|c|c|c|c|c|c|c|}
\hline \multirow{3}{*}{$\begin{array}{c}\text { Solution } \\
\text { Treatment } \\
\text { Temperature, } \\
\text { F } \\
\end{array}$} & \multicolumn{3}{|c|}{ As Solution Treated } & \multicolumn{3}{|c|}{ As Aged } \\
\hline & & 0.2 Per Cent & Ultimate & & 0.2 Per Cent & \\
\hline & $\begin{array}{l}\text { Elongation, } \\
\text { per cent }\end{array}$ & $\begin{array}{l}\text { Offset Yield } \\
\text { Strength, psi }\end{array}$ & $\begin{array}{c}\text { Strength, } \\
\text { psi } \\
\end{array}$ & $\begin{array}{l}\text { Elongation, } \\
\text { per cent }\end{array}$ & $\begin{array}{c}\text { Offset Yield } \\
\text { Strength, psi }\end{array}$ & $\begin{array}{c}\text { Ultimate } \\
\text { Strength。 psi }\end{array}$ \\
\hline 1450 & 13 & 87,500 & 114,000 & 7.5 & 121,500 & 152,000 \\
\hline 1525 & 13 & 67,000 & 106,000 & 0.5 & 155,000 & 177.000 \\
\hline 1600 & 17 & 78,000 & 114,000 & 2 & 178,000 & 190,000 \\
\hline
\end{tabular}

The Effect of Aging Temperature and Time. Increasing the aging temperature generally hastens the completion of the aging reaction, and it sometimes lowers the peak of the aging response. Increasing time generally increases strength up to a point, after which strength falls off and eventually elongation values increase.

The following data were selected from tests made on the zirconium$5 \mathrm{w} / 0$ niobium-2 w/o tin alloy, Heat B-2, solution treated at $1600 \mathrm{~F}$ and aged as indicated:

\begin{tabular}{|c|c|c|c|c|}
\hline $\begin{array}{c}\text { Aging } \\
\text { Temperature, } \\
\mathrm{F} \\
\end{array}$ & $\begin{array}{c}\text { Aging } \\
\text { Time, } \\
\text { hr } \\
\end{array}$ & $\begin{array}{c}\text { Elongation, } \\
\text { per cent } \\
\end{array}$ & $\begin{array}{l}0.2 \text { Per Cent Offset } \\
\text { Yield Strength, psi }\end{array}$ & $\begin{array}{c}\text { Ultimate } \\
\text { Strength, } \\
\text { psi }\end{array}$ \\
\hline \multirow[t]{3}{*}{900} & $1 / 2$ & 1.5 & 165,500 & 177,000 \\
\hline & 8 & 2.0 & 178,000 & 190,000 \\
\hline & 24 & 3.0 & 162.000 & 177,500 \\
\hline \multirow[t]{3}{*}{1000} & $1 / 2$ & 2.5 & 173,000 & 184,000 \\
\hline & 8 & 14.0 & 153,500 & 168,000 \\
\hline & 24 & $2.5(\mathrm{a})$ & 140,500 & 156,000 \\
\hline
\end{tabular}

(a) Defective specimen, broke in gage marks. 
Here, as in all the mechanical-testing work, too much reliance must not be placed on minor variations in properties. Most of the data represent duplicate specimens with good agreement between the two. However, experience has shown that there are often unpredictable minor variations from heat to heat and even within one heat. Only with considerable experience with an alloy is it possible to recognize and control the important variables. In addition, it is suspected that the presence of hydrogen in these materials may have had deleterous effects on the ductility, particularly of specimens in conditions of high strength. This latter factor was the subject of considerable investigation and is discussed in the section "Investigation Into The Effects of Hydrogen". At any rate, the data do show well-established trends. Individual values may not be particularly representative, however.

Summarizing, the zirconium alpha-beta alloys respond to heat treatment much as titanium alpha-beta alloys, showing both the omega and the alpha-prime aging reactions, depending on composition and heat-treatment history. The reactions observed are sufficiently complex as to preclude the attainment of optimum composition and heat treatment without considerable detailed research effort. Therefore, the properties observed thus far can in no way be considered typical. There is every reason to expect that considerable additional improvement could be obtained.

\section{Alpha Alloys}

The early investigations of heat treatment included some study of alpha alloys. These alloys included Zircaloy 2 , a zirconium-2 w/o tin$2 \mathrm{w} / \mathrm{o}$ molybdenum alloy, a zirconium-4 w/o tin-2 w/o molybdenum alloy, and a zirconium $-4 \mathrm{w} / 0 \mathrm{tin}-1 \mathrm{w} / 0$ molybdenum- $1 / 2 \mathrm{w} / 0 \mathrm{chromium}-1 / 4 \mathrm{w} / \mathrm{o}$ nickel alloy. The heat treatments and resultant mechanical properties are described in detail in Table B-2 in Appendix B.

While some alloys showed considerable increase in strength after some heat treatments, none retained useful ductility in the high-strength condition. Zircaloy 2 , for example, showed no heat-treatment response except for about a 20 per cent increase in strength and a 50 per cent decrease in ductility after quenching from the beta field. Of the other alloys, any heat treatment that raised the ultimate strength above $140,000 \mathrm{psi}$ also reduced the elongation to less than 1 per cent.

These alloys were not studied further because of their poor heattreatment response. This is attributed to the fact that the alloys contain insufficient quantities of beta-stabilizing elements to permit retention of the beta phase to low temperatures for subsequent transformation by the omega or alpha-prime reactions. 


\section{Elevated-Temperature Tensile and \\ Stress-Rupture Properties}

After screening the compositions and heat treatments by means of room-temperature properties, a limited evaluation of strength properties was made at elevated temperature. Two alloys, the zirconium $-5 \mathrm{w} / \mathrm{o}$ molybdenum-2 w/o tin and the zirconium-5 w/o niobium-2 w/o tin, were tested in the maximum-strength condition of heat treatment in both shorttime tensile tests and stress-rupture tests.

The tests were conducted at $840 \mathrm{~F}$. This temperature was chosen on the assumption that it lies just below the temperature at which any curve relating mechanical properties or creep rate of alpha-beta zirconium alloys to temperature makes a sharp break. This assumption is based on a limited survey of the small amount of elevated-temperature testing of zirconium alloys that has been reported.

In the short-time tensile tests, specimens were held $1 / 2 \mathrm{hr}$ at temperature in a flowing-helium atmosphere before testing. The same extensometer was used as for room-temperature tests and the strain rate was also the same, i.e., 0.01 in. per min to the yield stress, 0.05 in. per min to failure.

Results of the tensile tests at $840 \mathrm{~F}$ were as follows:

\begin{tabular}{|c|c|c|c|c|}
\hline Alloy & Heat Treatment & $\begin{array}{c}\text { Elongation in } 1 \mathrm{In}_{0} . \\
\text { per cent }\end{array}$ & $\begin{array}{l}0.2 \text { Per Cent Offset } \\
\text { Yield Strength, psi }\end{array}$ & $\begin{array}{c}\text { Ultimate } \\
\text { Strength, } \\
\text { psi } \\
\end{array}$ \\
\hline $\mathrm{Zr}-5 \mathrm{Mo}-2 \mathrm{Sn}$ & $\begin{array}{l}\text { Solution treated at } 1525 \mathrm{~F} \\
\text { and aged } 8 \mathrm{hr} \text { at } 1000 \mathrm{~F}\end{array}$ & $\begin{array}{l}14 \\
10\end{array}$ & $\begin{array}{l}84,000 \\
85,000\end{array}$ & $\begin{array}{l}113,500 \\
108,500\end{array}$ \\
\hline $\mathrm{Zr}_{r}-5 \mathrm{Nb}-2 \mathrm{Sn}$ & $\begin{array}{l}\text { Solution treated at } 1600 \mathrm{~F} \\
\text { and aged } 8 \text { hr at } 900 \mathrm{~F}\end{array}$ & $\begin{array}{r}5 \\
10\end{array}$ & $\begin{array}{l}94,000 \\
98,000\end{array}$ & $\begin{array}{l}120,000 \\
126,000\end{array}$ \\
\hline $\begin{array}{l}\text { 1.8-8 stainless } \\
\text { steel, Type } \\
304(a)\end{array}$ & Cooled rapidly from $2000 \mathrm{~F}$ & 47 & 15,000 & 62,000 \\
\hline $\mathrm{Zr}-4 \mathrm{Sn}-2 \mathrm{MO}(\mathrm{a})$ & $\begin{array}{l}\text { Cold rolled, annealed at } \\
1345 \mathrm{~F} \text { and furnace cooled }\end{array}$ & 40 & 35,000 & 47,000 \\
\hline
\end{tabular}

(a) Data on the stainless steel and the zirconium $-4 \mathrm{w} / \mathrm{o}$ tin-2 $\mathrm{w} / \mathrm{o}$ molybdenum alloy, from References (12) and (13), respectively, are listed for comparison. 
Specimens given identical heat treatments were tested in an attempt to determine the 100-hr rupture stress. These tests were conducted in a vacuum and the results were as follows:

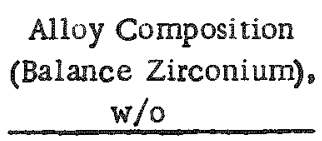

$5 \mathrm{MO}-2 \mathrm{Sn}$

$5 \mathrm{Mo}-2 \mathrm{Sn}$

$5 \mathrm{Nb}-2 \mathrm{Sn}$

$5 \mathrm{Nb}-2 \mathrm{Sn}$

$5 \mathrm{Nb}-2 \mathrm{Sn}$

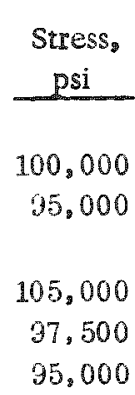

Time to
Failure, hr

Fallure, hr

2.4

147.9

1. 5

4.8

5.1
Time to Produce Indicated

$\frac{\text { Elungation, hr }}{1 \% \quad 2 \%}$

$-\cdot$

0.5

0.3

5.5

0.8

12.2

0.12

0.39

0.7

1.4

2. 4
Total Elongation, per cent

18.8

26.0

8.0

13.5

11.5

The data for the molybdenum alloy appear to be consistent and indicate that in this condition of heat treatment the alloy has some very interesting potentialities. Extrapolation of the data to $500 \mathrm{hr}$, although such extrapolation is of questionable value, indicates a rupture stress higher than the short-time tensile strength for Type 304 stainless steel.

The data for the niobium alloy are somewhat erratic. Time and funds did not permit additional testing. The data suggest, however, that the alloy should be heat treated to a more stable condition, and the first logical step would be to raise the aging temperature somewhat. Some sacrifice in roomtemperature strength might be necessary to promote superior performance at elevated temperature.

\section{METALLOGRAPHIC EXAMINATION}

The preparation of metallographic specimens, except for the final polish and etch, was conventional. Solution-treated specimens were mounted in Epon, a plastic which will set at room temperature, to prevent any low-temperature aging effect. All other specimens were mounted in Bakelite. The mounted specimens were then polished through 600-grit silicon carbide Wetordry paper using water. They were then polished on a high-speed wheel (1750 r pm) using aluminum oxide in water as an abrasive.

The final polishing and etching in most cases were accomplished by vigorous swabbing with a mixture of commercial ( 85 per cent) lactic acid, concentrated (70 perr cent) nitric acid, and hydrofluoric acid (48 per cent). The lactic acid-to-nitric acid ratio varied from $1: 1$ to $3: 1$ with about $1 / 2$ to 1 per cent of hydrofluoric acid added. The concentrations were varied to control the contrast and polishing action and were dependent upon the material and its heat treatment. 
If, after swabbing vigorously with the above solution, the specimen did not show enough contrast in phases, the contrast could be increased by a stain etch. Specimens were stain etched with $5 \mathrm{w} / 0$ ammonium bifluoride solution applied by pouring while the specimen was still wet with the chemical polish.

The chemical polish was necessary to remove the worked metal from the surface of the zirconium alloys. These alloys were extremely difficult to polish without smearing metal. The chemical polish gave the most nearly consistent results. However, even with the most meticulous procedures, the microstructures observed did not correlate well with properties or $\mathrm{X}$-ray diffraction analyses. As a result, few photomicrographs were taken.

Figure 11 shows the zirconium-5 w/o molybdenum-2 w/o tin alloy quenched from $1525 \mathrm{~F}$. The structure consists mainly of equiaxed alpha in a beta matrix. There are wavy, nearly parallel lines (oriented vertically in the photomicrograph) that appear in the beta matrix. Lines similar to these have been observed under several conditions of heat treatment. They may represent areas of transformed beta, the transformation being strain induced during polishing. They may represent etching artifacts. Consideration of $\mathrm{X}$-ray data and the known phase reactions fails to explain these markings as an equilibrium phase. Their orientation perpendicular to the direction of rolling may or may not have some significance.

Figure 12 shows the same alloy after aging $1 / 2 \mathrm{hr}$ at $900 \mathrm{~F}$. The same metallographic procedures have produced evidence of what appear to be grain boundaries of very small beta grains. Their appearance is not very different from the wavy lines observed in Figure 11, but the geometry is entirely different. Additional aging usually made these grain boundaries more pronounced and late in the aging cycle another phase was found in the grain-boundary regions, presumably $\mathrm{ZrMO}_{2}$.

Figure 13 shows the zirconium $-5 \mathrm{w} / 0$ niobium-2 w/o tin alloy after solution treating at $1525 \mathrm{~F}$ and aging $1 / 2 \mathrm{hr}$ at $900 \mathrm{~F}$. The primary alpha grains are elongated in the direction of rolling, indicating that they had formed prior to or during the rolling operation. Actually, because of cross rolling, which elongates in two directions, the alpha grains are more probably plates, nearly equal in dimensions in two directions and considerably shorter in the third. The matrix here is alpha prime and is distinguished from retained beta by the random, very faint markings.

The same alloy after aging $48 \mathrm{hr}$ at $1100 \mathrm{~F}$ is shown in Figure 14. Here the primary alpha grains are in a matrix that is secondary alpha (formed from the quenched alpha prime) containing a precipitate of the niobium solid solution. This precipitate appears to be almost coarse enough at this stage to be resolved. At earlier stages of aging, the matrix will be darkened by the etchant, but to a lesser degree. 
FIGURE 11. ZIRCONIUM-5 w/O MOLYBDENUM-2 w/O TIN ALLOY SOLUTION TREATED AT $1525 \mathrm{~F}$ Equiaxed alpha in a beta matrix; note unidentified vertical wavy lines.

$500 x \quad$ Mixed Acids Plus Ammonium Bifluoride Etch $\quad$ N31790

FIGURE 12. ZIRCONIU-5 W/O MOLIBDENUM-2 W/O TIN ALLOY SOLUTION TREATED AT 1525 F AND AGED $1 / 2$ HR AT $900 \mathrm{~F}$

Equiaxed alpha in a beta matrix; note more complete formation of beta grain boundaries. 
N31787

FIGURE 13. ZIRCONIUM-5 W/O NIOBIUM=2 $w / 0$ TIN ALLOY QUENCHED FROM 1525 F AND AGED $1 / 2$ HR AT 900 F

Equaxed alpha in a transformed beta (alpha prime) matrix.

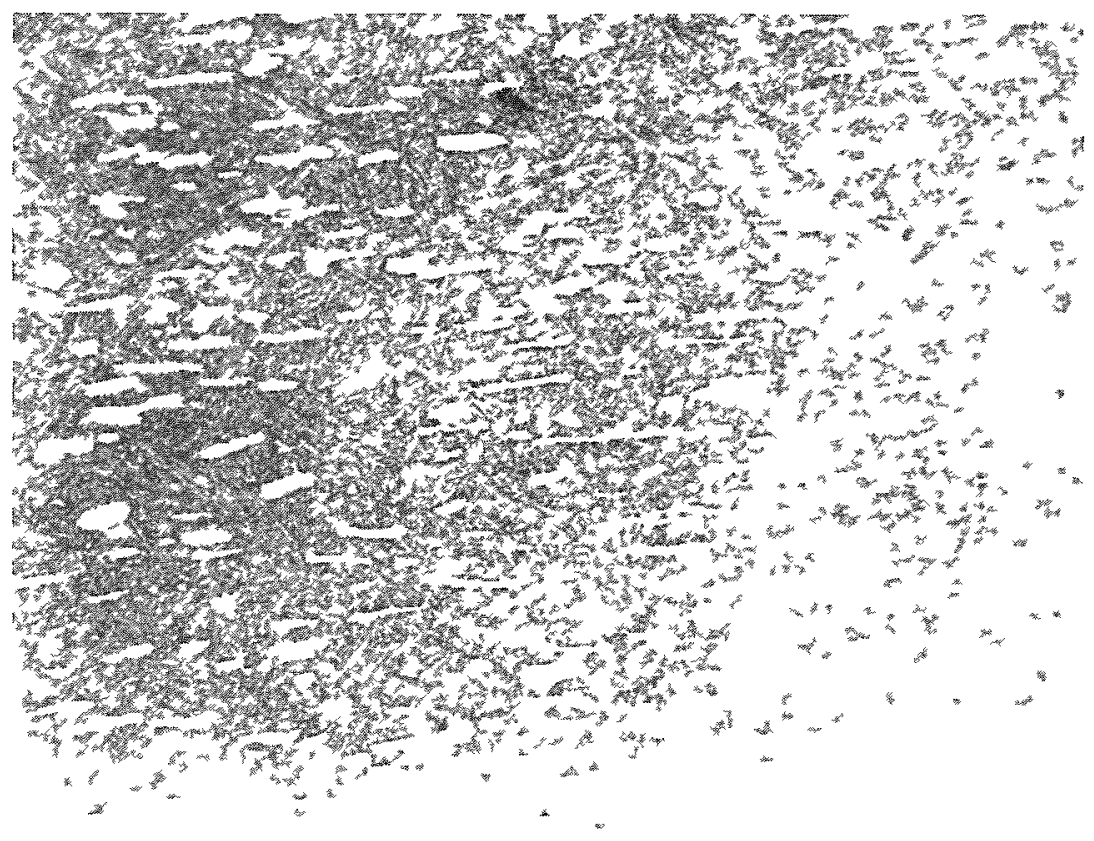

$500 x$

Mixed Acids Etch

N31783

FIGURE 14. ZIRCONIUM 5 W/O NIOBIUM-2 $w / 0$ TIN ALLOY QUENCHED FROM 1525 F AND AGED $48 \mathrm{HR}$ AT $1100 \mathrm{~F}$

Elıngated alpha in a matrix of alpha plus nobium solid solution. 
In the metallographic studies, lines of a different sort were found occasionally in some specimens. These often had the appearance of the hydride phase, although the amount observed was often more than would be expected except in a material with very high hydrogen contents. This structure sometimes could not be found if the specimen were reground and repolished. On at least one occasion additional etching alone caused it to disappear.

Because of this peculiar behavior and because of a concern that the presence of hydride could be causing some of the low elongation values, a study of the effect of hydrogen was made.

\section{INVESTIGA TION INTO THE EFF ECTS OF HYDROGEN}

The reported effects of hydrogen on the mechanical properties of unalloyed zirconium and titanium are similar. (14, 15) The principal effect is a reduction in notched-bar impact properties. Increasing hydrogen contents cause only a slight decrease in tensile ductility of zirconium and no effect on the tensile ductility of titanium. Hydrogen contents in the range of 20 to $60 \mathrm{ppm}$ have been shown to produce a needlelike phase in the microstructure of both unalloyed zirconium and titanium. $(14,16,17)$ Alpha alloys of zirconium-tin are affected by hydrogen the same as unalloyed metal.

In alpha-beta alloys of titanium, however, the effect of hydrogen is much different. There appears to be little if any effect on notched-bar impact properties, but a pronounced strain-rate sensitivity is found in the tensile tests. $(18,19)$ Loss of tensile ductility at slow strain rates was shown at a hydrogen level as low as $90 \mathrm{ppm}$ when one titanium alloy was heat treated to strengths of about 170,000 psi. (19) This concentration of hydrogen in titanium alpha-beta alloys did not produce a phase in the microstructure that could be associated with hydrogen. However, in certain conditions of heat treatment, hydrogen levels of 140 ppm or higher did produce a hydride phase. This phase was identified by autoradiography using tritium as a tracer, and was shown to occur at the interface of the alpha and beta phases. (20) The mechanism of hydrogen embrittlement of titanium alphabeta alloys has not been established; it is believed to be a strain-aging phenomenon. However, the location of the hydride at alpha-beta interfaces, while not necessarily associated with strain aging, is obviously not conducive to good mechanical properties.

Because of the rather generally low ductility of the zirconium alloys, hydrogen was suspected to be the cause, the same as in titanium alloys. Therefore, two avenues of exploration were undertaken to a limited extent to determine the effect of hydrogen in alpha-beta zirconium alloys. The first was an evaluation of the effect of hydrogen on tensile properties. The 
second was an attempt to identify a phase which appeared in the alloys to determine whether or not it was a hydride.

\section{Effect of Hydrogen on Tensile Properties}

Hydrogen contents above about $150 \mathrm{ppm}$ are known to reduce tensile ductility of titanium alloys when heat treated to high strength levels. Similarly, high-hydrogen titanium alloys will fail at low elongation levels when strained at low rates, because of strain-aging precipitation of hydrogen. Both phenomena were investigated in the two zirconium alloys.

To observe the effect on tensile ductility, stock of two alloys was vacuum annealed $8 \mathrm{hr}$ at $1350 \mathrm{~F}$ to reduce the hydrogen content, then it was compared with untreated material. Both materials were solution treated at $1525 \mathrm{~F}$ and aged $8 \mathrm{hr}$ at $1000 \mathrm{~F}$. The results of this investigation were as follows:

\begin{tabular}{|c|c|c|c|c|c|}
\hline Alloy ${ }^{(a)}$ & Pretreatment & $\begin{array}{c}\text { Hydrogen } \\
\text { Content, } \\
\text { ppm } \\
\end{array}$ & $\begin{array}{l}\text { Elongation in } \\
2 \mathrm{In} \text {. : per cent } \\
\end{array}$ & $\begin{array}{l}0.2 \text { Per Cent Offset } \\
\text { Yield Strength, psi }\end{array}$ & $\begin{array}{c}\text { Ultimate } \\
\text { Tensile } \\
\text { Strength, } \\
\text { psi } \\
\end{array}$ \\
\hline$A-4$ & None & 31 & 0.7 & 172,000 & 179,000 \\
\hline$A-4$ & Vacuum annealed & 25 & 0.7 & 174,000 & 184,000 \\
\hline$A-6$ & None & 47 & 10.5 & 150,000 & 160,000 \\
\hline$A-6$ & Vacuum annealed & 23 & 10.5 & 150,000 & 161,500 \\
\hline
\end{tabular}

(a) $A-4$ is zirconium $-5 \mathrm{w} / 0$ molybdenum $-2 \mathrm{w} / 0$ tin; $A-6$ is zirconium $-5 \mathrm{w} / 0$ niobium $-2 \mathrm{w} / 0$ tin.

While a substantial reduction in the hydrogen content was effected by vacuum annealing, there seems to have been no improvement in tensile ductility at this strain rate. Attempts to produce sheet tensile specimens with substantially lower hydrogen contents met with little success because of an increased rate of pickup of hydrogen during the pickling operations. Time and funds did not permit developing a new procedure that would overcome this difficulty.

A substantial increase in tensile ductility has been observed in titanium alloys containing hydrogen when the strain rate is increased markedly. The effect was explored in two zirconium alloys, the $5 \mathrm{w} / 0$ molybdenum$2 \mathrm{w} / 0$ tin (Alloy $\mathrm{C}-49$ ) and the $5 \mathrm{w} / 0$ niobium-2 w/o tin (Alloy B-2). The materials with substantially equivalent hydrogen contents at about $30 \mathrm{ppm}$ were heat treated to three strength levels and tested at three strain rates. Results of these tests are shown in Table 8: 
TABLE 8. EFFECT OF STPAIN DATE ON TEMGRLE RROPERTES OF TWO ZRCOHUMA ALLOYS

\begin{tabular}{|c|c|c|c|c|}
\hline Alloy & $\begin{array}{l}\text { Strain Rate }{ }^{(a)} \text {, } \\
\text { in. per min }\end{array}$ & $\begin{array}{c}\text { Elongation in } \\
1 \text { In. (b), per cent }\end{array}$ & $\begin{array}{c}\text { Reduction of } \\
\text { Area(b), per cent }\end{array}$ & $\begin{array}{l}\text { Ultimate Tensile } \\
\text { Strength(b), psi }\end{array}$ \\
\hline$C-49^{(c)}$ & 0.006 & 7.5 & 24 & 169,000 \\
\hline$C-49(c)$ & $0.01-0.05$ & 11 & 20 & 168,500 \\
\hline$C-49(c)$ & 0.25 & 3 & 22 & 170,500 \\
\hline$C-49^{(d)}$ & 0.006 & $\eta^{(e)}$ & $29(e)$ & 151,000 \\
\hline$C-49^{(d)}$ & $0.01-0.05$ & 3 & 38 & 154,000 \\
\hline$C-4 g(d)$ & 0.25 & $6(\mathrm{e})$ & 38 & 154,000 \\
\hline$B-2(1)$ & 0.006 & 4.5 & 14 & 178,000 \\
\hline$B-2(f)$ & $0.01-0.05$ & $2.5^{(e)}$ & $g^{(e)}$ & 177,500 \\
\hline$B-2^{(f)}$ & 0.25 & 2.5 & 14 & 183,000 \\
\hline
\end{tabular}

(a) Determined by crosshead speed: $0.01-0.05$ indicates $0.01 \mathrm{in}$. per min to the yield strength and then 0.05 in. per min to fracture.

(b) Average of two values except where noted.

(c) Solution treated at $1525 \mathrm{~F}$ and aged $48 \mathrm{hr}$ at $900 \mathrm{~F}$.

(d) Solution treated at $1525 \mathrm{~F}$ and aged $24 \mathrm{hr}$ at $1000 \mathrm{~F}$.

(e) Single values.

(f) Solution treated at $1600 \mathrm{~F}$ and aged $24 \mathrm{hr}$ at $900 \mathrm{~F}$.

The variations in strength and ductility values are perhaps a little more than normal experimental variations. However, sheet specimens often exhibit such variations due to surface imperfections. It must be concluded that the variation in strain rate had no significant effect on the tensile ductility or strength of these alloys. This indicates that, at least in these limited tests, a hydrogen content of $30 \mathrm{ppm}$ did not cause the alloys to be strain-rate sensitive. It seems unlikely, therefore, that hydrogen could have caused the low ductility in the alloys heat treated to high strength levels.

The Effect of Hydrogen on the Microstructure

As mentioned earlier, the identification of a hydride phase at the alpha-beta interfaces was believed to result in lowered ductility in highstrength alpha-beta titanium alloys. The hydride phase was identified by autoradiography using tritium as a tracer for the hydrogen. The positive identification of a hydride phase in zirconium alloys of low ductility would be sufficient reason for the low ductility.

A mixture of tritium and hydrogen was added to alloy samples in a modified Sieverts apparatus. One sample of each of the zirconium-5 w/o molybdenum-2 w/o tin and the zirconium $-5 \mathrm{w} / 0$ niobium-2 w/o tin alloys 
was loaded with 100 or $200 \mathrm{ppm}$ of the mixed gases. The quantity of tritium added was expected to produce 25 or 50 millicuries of radioactivity at the 100- or 200-ppm level of hydrogen, respectively. The additions were made as follows:

1. Individual $1 / 2$ by $1 / 2$ by $1-3 / 16$ in. specimens of each alloy were abraded with dry 240-grit silicon carbide paper and placed in a Vycor tube of a modified Sieverts apparatus.

2. Specimens were degassed for $15 \mathrm{~min}$ at $1470 \mathrm{~F}$ to a vacuum of at least $0.05 \mu$ of mercury.

3. The temperature was lowered to $1110 \mathrm{~F}$ and the measured volume of tritium-hydrogen mixture added to the reaction tube. The progress of the reaction was followed by pressure readings on an open-end manometer.

4. When the reaction was completed, the specimens were cooled in the reaction tube, removed and sealed in individual evacuated Vycor capsules.

5. The specimens in the capsules were then heated for $24 \mathrm{hr}$ at $1550 \mathrm{~F}$ for homogenization, and subsequently air cooled in the capsule.

The specimens were then rolled to about 0.060-in.-thick sheet, using the same technique adopted as standard practice for the whole program. Care was taken to keep the rolling reduction and the orientation with respect to the original forged direction the same as for the large bars rolled to sheet. This was done to assure the same microstructure in the tritium bearing sheet as was obtained in the original sheet. However, as will be noted later, the tritium-bearing specimens did have somewhat larger alpha grain size. Processing of the tritium-bearing sheet was the same as that used for the age-hardening study except that all aging treatments for the tritium alloys were carried out in evacuated Pyrex capsules.

The heat-treated tritium-bearing specimens were mounted in Bakelite, polished and etched as discussed in the section on "Metallographic Examination". Photomicrographs were made of sperimens showing significant structural changes.

The autoradiographs of all specimens were obtained as follows:

1. The polished and etched specimens were coated with a Vinylite plastic, using great care to keep the coating about 0.001 in. thick so that the beta radiation from the tritium would not be shielded from the sensitized film. 
2. The autoradiographic film was placed on the specimens hy 7 wet technique.

3. After about 2 days of exposure, the film was developed in place on the specimens.

4. Photomicrographs were then taken of the exposed film in place on the specimen.

The photomicrographs are presented as pairs, with the microstructure at the left of each pair and the autoradiograph (superimposed on the microstructure) at the right. There was very little difference in the appearance of the specimens containing $100 \mathrm{ppm}$ of hydrogen as compared with the specimens containing $200 \mathrm{ppm}$. Therefore, photomicrographs are shown only of the 100-ppm specimens.

The as-quenched structure of the niobium-bearing alloy, in Figure 15, shows equiaxed primary alpha in transformed beta. The exposed silver grains in the film show random and uniform distribution of the hydrogen, indicating either $r$ andom precipitation or retention in solid solution.

The as-quenched structure of the molybdenum-bearing alloy is shown in Figure 16. The peculiar line markings discussed earlier are observed in the microstructure along with other structures that cannot be explained in terms of the metallic phases expected. The concentration of hydrogen in these phases, as indicated by the autoradiograph, provides partial explanation of the observed microstructure.

However, there are several reasons to doubt that these observations are representative of the material. First, the general level of activity indicates much more hydrogen in Figure 16 than in Figure 15, although the hydrogen (tritium) contents are nominally equal. Secondly, if the amount of hydride indicated by the autoradiograph were present in the total volume of the specimen, it seems improbable that the specimen could have developed the 10 per cent elongation typical for this material in this condition of heat treatment. Finally, the structure was completely erradicated by aging $1 / 2 \mathrm{hr}$ at $900 \mathrm{~F}$. This heat treatment produced a microstructure very like that shown in Figure 15.

There seems to be a very real possibility that the structures, even as revealed by autoradiography, may be surface phenomena related to hydrogen pickup during polishing and etching. The diffusivity of hydrogen is quite high and the several days between sample preparation and final autoradiographic exposure may have been sufficient for an interchange of tritium between the body of the specimen and the surface phases. Subsequent 


\section{X Photomicrograph}

N31788

Mxed Acids Etch

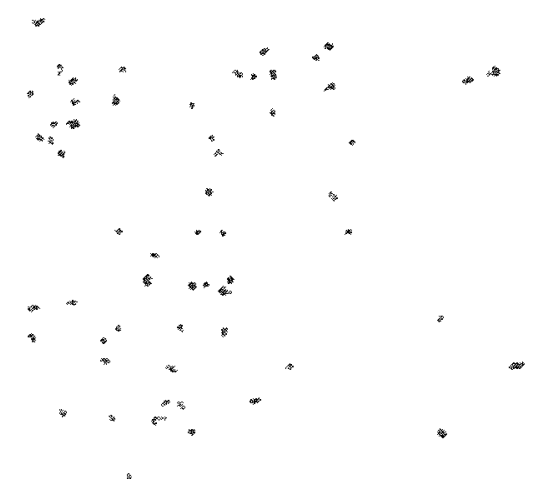

FIGURE 15. ZIRCONIUM-5 W/O NIOBIUM-2 W/O TIN ALLOY SOLUTION TREATED AT $1525 \mathrm{~F}$

Random distribution of exposed silver grains indicates random hydrogen distribution.

$500 \times$

Photomicrograph $\quad$ N31789
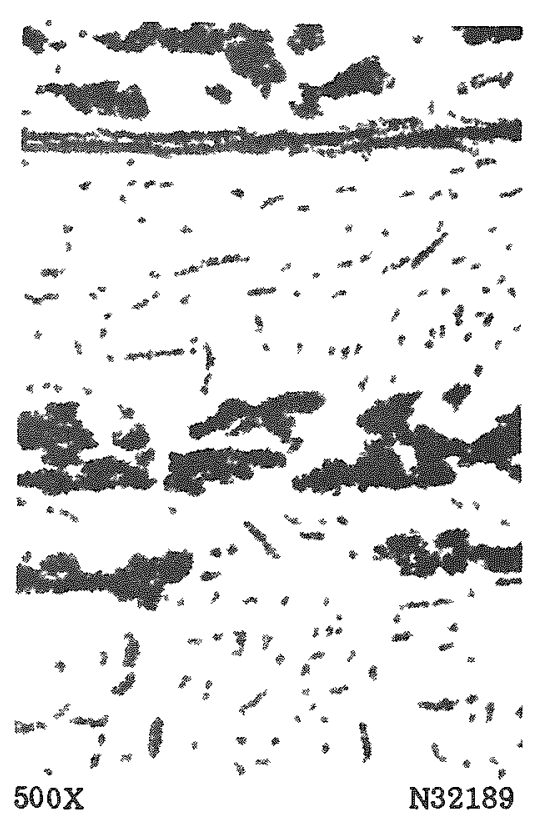
$500 X$ Autoradiograph Mixed Acids Plus Ammonium Bifluoride Etch

FIGURE 16. ZIRCONTUM-5 W/O MOLIBDENUM-2 W/O TIN ALLOY SOLUTION TREATED AT 1525 F Note apparent segregation of hydrogen. However, amount seems unusually great. 
aging could diffuse the surface hydrogen (and tritium) into the body of the specimen. Why the polishing and etching procedure introduces hydrogen (if this be the case) during some preparation operations and not others is not explainable at this time.

Segregation of hydrogen during aging is shown by the microstructures in Figures 17 and 18. Figure 17 is the structure of the zirconium-5 w/o niobium-2 w/o tin alloy solution treated at $1525 \mathrm{~F}$ and aged $48 \mathrm{hr}$ at $1100 \mathrm{~F}$. Figure 18 is the structure of the zirconium-5 w/o molybdenum-2 w/o tin alloy solution treated at $1525 \mathrm{~F}$ and aged 8 hours at $900 \mathrm{~F}$. Both autoradiographs show some concentration of hydrogen at the interface between the elongated primary alpha grains and the matrix. In addition, there are concentrations of hydrogen in areas relatively free of alpha grains. For the niobium alloy, Figure 17, these often appear diagonally in the microstructure and are possibly associated with hydride needles precipitating between the alpha prime needles, as observed in unalloyed zirconium by Mudge (14) or Saller(16).

At intermediate aging times, a network of apparent beta grains was shown in Figure 12. This network, more fully developed by longer aging, as shown in Figure 19, apparently does not contain any concentration of hydrogen, as shown in the autoradiograph.

In conclusion, the effect of hydrogen on ductility of alpha-beta zirconium alloys has not been well defined. There does appear to be an interfacial precipitation which could cause embrittlement similar to that found in alpha-beta titanium alloys. However, good ductility has been obtained for certain conditions of heat treatment which have also caused the hydrogen segregation represented by the autoradiographs shown. While the evidence is not conclusive, the observations do not positively indicate that hydrogen has been the direct cause of elongation values somewhat lower than those found in titanium alloys of equivalent strengths.

\section{RECOMMENDATIONS FOR FUTURE WORK}

It was the purpose of the research reported here to demonstrate that zirconium-base alloys could be heat treated to provide high strengths with adequate ductility. This purpose has been accomplished, along with a very brief examination of elevated-temperature strengths of two alloys. However, before any zirconium-base alloys can be put into service as high-strength structural materials, considerable additional research is necessary.

Because of the limited time and funds available, the detailed study of heat treatment had to be conducted on compositions that were chosen without a real survey of alloy compositions. Therefore, a thorough investigation 


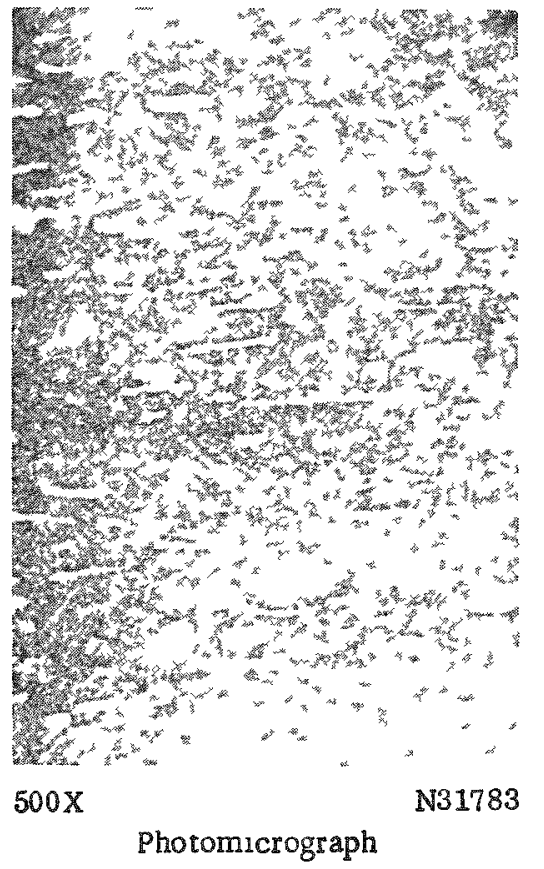

Muxed Acids Etch

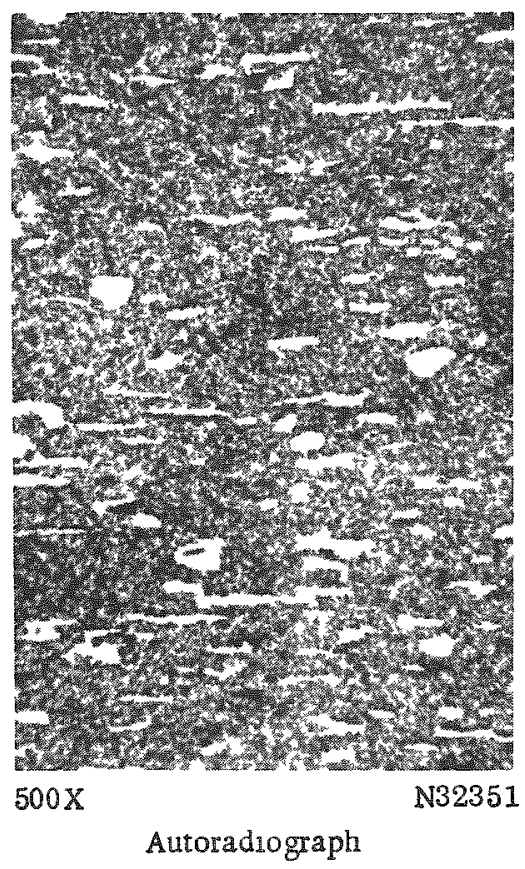

Autoradiograph

FIGURE 17. ZIRCONIUM-5 W/O NIOBIUM-2 w/O TIN ALLOY SOLUTION TREATED AT 1525 F AND AGED 48 HR AT $1100 \mathrm{~F}$

Elongated alpha grams in a matrix of alpha and termnal solid solution.

Note: Concentration of silver grains at alpha grain boundaries and also come diagonally oriented.

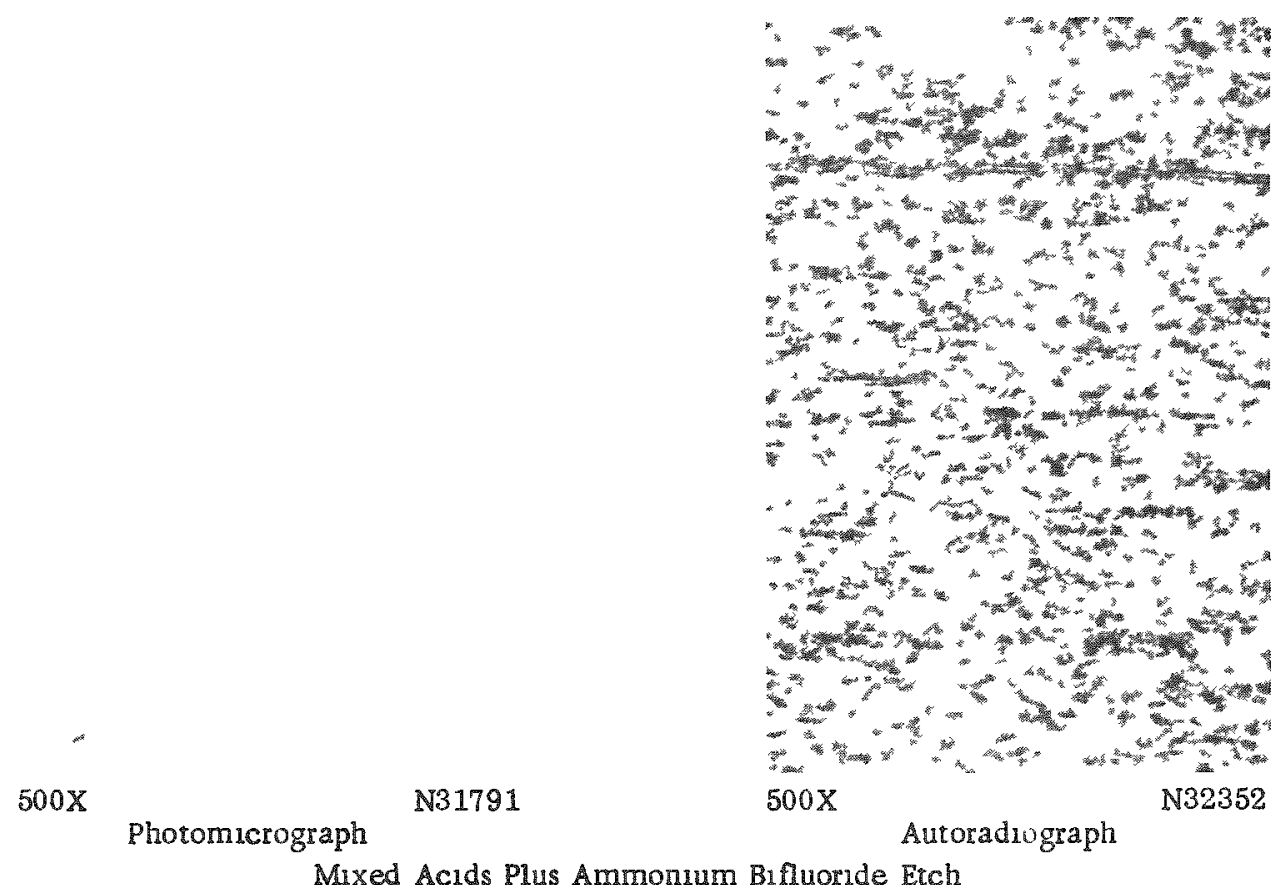

FIGURE 18. ZIRCONIUM $-5 \mathrm{w} / 0$ MOLYBDENUM-2 $w / 0$ TIN ALLOY SOLUTION TREATED AT 1525 F AND AGED 8 HR AT $900 \mathrm{~F}$

Alpha in beta matrix, showing concentration of hydrogen at alpha-beta interfaces plus concentrations generally parallel to alpha grains. 


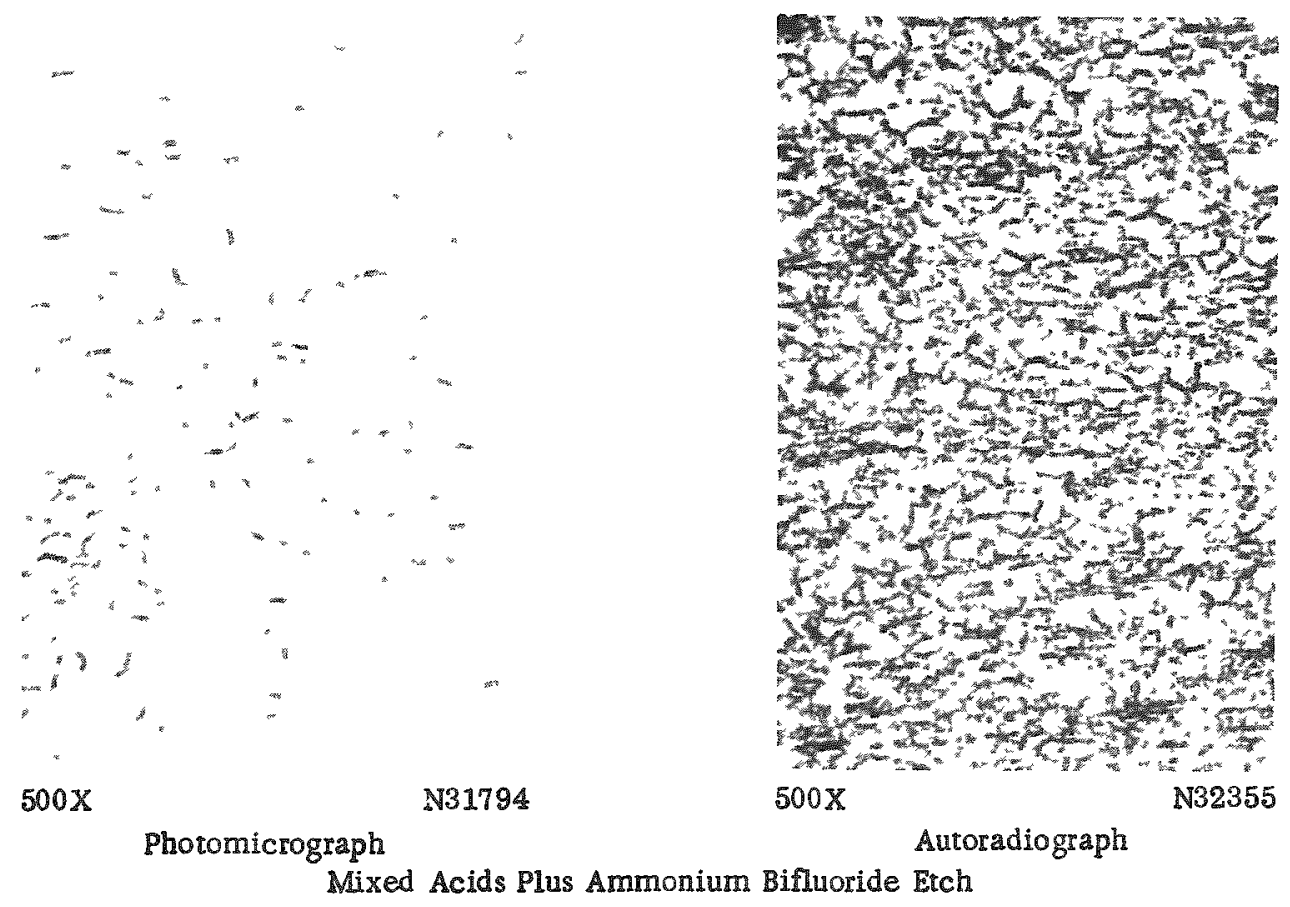

FIGURE 19. ZIRCONIUM-5 w/o MOLYBDENUM-2 w/o TIN ALLOY SOLUTION TREATED AT $1525 \mathrm{~F}$ AND AGED 8 HR AT $1000 \mathrm{~F}$

Exposed silver grains are not concentrated at beta grain boundaries. 
of other alloy compositions should be made. This investigation should include, as a minimum, the study of molybdenum and niobium at lower and higher concentrations, the molybdenum to as high as $10 \mathrm{w} / 0$, the niobium to as high as $20 \mathrm{w} / 0$. Several levels of alpha stabilizers, tin and aluminum, should also be investigated. Ultimately, a study of the effect of various concentrations of the impurities oxygen, nitrogen, and carbon should be made.

Additional heat-treatment studies should be made. The investigation of the effect of composition must be made using a limited selection of heat treatments. Subsequently, a few of the more promising compositions should be studied in a detailed heat-treatment study. This study should include enough $\mathrm{X}$-ray diffraction and metallographic work to define the phase reactions occuring during aging. It would probably not be necessary to determine the crystal structure of the transition phase or phases, but it would be instructive to do so.

Additional investigation of the effects of hydrogen is mandatory.

Finally, studies should be made that would define the limits of end use. These should include studies of corrosion in the media of interest, development of elevated-temperature engineering design data, and studies of the stability of room- and elevated-temperature mechanical properties after long exposure to temperatures and environment of application.

\section{REFERENCES}

(1) Frost, P. D., et al., "Isothermal Transformation of TitaniumChromium Alloys", Trans. ASM, 46, 568 (1954).

(2) Parris, W. M., et a1., "Heat Treatment of High Strength TitaniumBase Alloys", Trans. ASM, 46, 568 (1954).

(3) "A Study of Factors Affecting the Uniform Elongation of Titanium and Titanium Alloys", WADC Technical Report 55-454, Part I, Battelle Memorial Institute (June, 1955).

(4) Domogala, R. F., McPherson, D. J., and Hansen, M., "Systems Zirconium-Molybdenum and Zirconium-Wolfram", J. Metals, 5, 74 (1953).

(5) Rogers, B. A., and Atkins, D. F., "Zirconium-Columbium Diagram", J. Metals, 2, 1036 (1955). 
(6) WADC Technical Report No. 54-355, Parts I and I, Rattelle Memarial Institute (June, 1954 and February, 1955).

(7) Austin, A. E., and Doig, J. R., "Structure of the Transition Phase, Omega, in a Titanium-Chromium Alloy", to be published.

(8) Silcock, J. M., Davis, M. H., and Hardy, H. K., "Structure of the Omega-Precipitate in Titanium 16 Per Cent Vanadium Alloy", Nature, 175, 731 (Apri1 23, 1955).

(9) Bagariatskii, Iv. A., Nosova, G. I., Tagunova, T. V., "On the Crystal Structure and Nature of the Omega Phase in Alloys of Titanium and Chromium", Doklady Akad. Nauk, S.S.S.R., 105, 1225-1228 (1955).

(10) Yoshida, S., Yoshida, H., Araki, T., and Tsuya, Y., "Age Hardening of Titanium-Iron Alloys", J. Mechanical Laboratory of Japan, 1 (1), $10-13(1955)$.

(11) Delazaro, D. J., and Rostoker, W., "The Influence of Oxygen Contents on Transformations in a Titanium Alloy Containing 11 Per Cent Molybdenum", Acta Metallurgica, 1, 674 (1953).

(12) "Steels for Elevated Temperature Service", United States Steel, Pittsburgh, Pennsylvania (1952).

(13) Chubb, W., Meuhlenkamp, G. T., and Manning, G. K., "A High Strength Zirconium Alloy: Zirconium-4 w/o Tin-1.6 w/o Molybdenum", BMI- 987 (March 18, 1955).

(14) Mudge, W. L., Jr., "Effect of Hydrogen on the Embrittlement of Zirconium and Zirconium-Tin Alloys", WAPD-59 and T-20 (1952).

(15) Jaffee, R. I., and Campbe11, I. E., "The Effect of Oxygen, Nitrogen, and Hydrogen on Iodide Refined Titanium", Trans. AIME, 185, 646 (1949).

(16) Saller, H. A., and Dickerson, R. F., "Metallographic Identification of Nonmetallic Inclusions in Zirconium", BMI-74 (July, 1951).

(17) Craighead, C., Lenning, G., and Jaffee, R. I., "Nature of the Line Markings in Titanium and Alpha Titanium Alloys", J. Metals, 4 , 1317 (1952).

(18) "The Effect of Hydrogen on the Mechanical Properties of Titanium and Titanium Alloys", Summary Report to Watertowr Arsenal, Contract No. DA-33-019-ORD-938, p 21 (July 31, 1954). 
(19) WADC Technical Report 54-205, Part II, Battelle Memorial Institute, p 70 .

(20) Huber, O. J., et al., "Hydrogen Distribution in Heat-Treated Titanium Alloys as Established by Autoradiography", submitted to AIME for publication.

HAR:JRD:MWM:PDF/dc 
APPENDIX A

SUPPLEMENTARY AGE-HARDENING DATA 


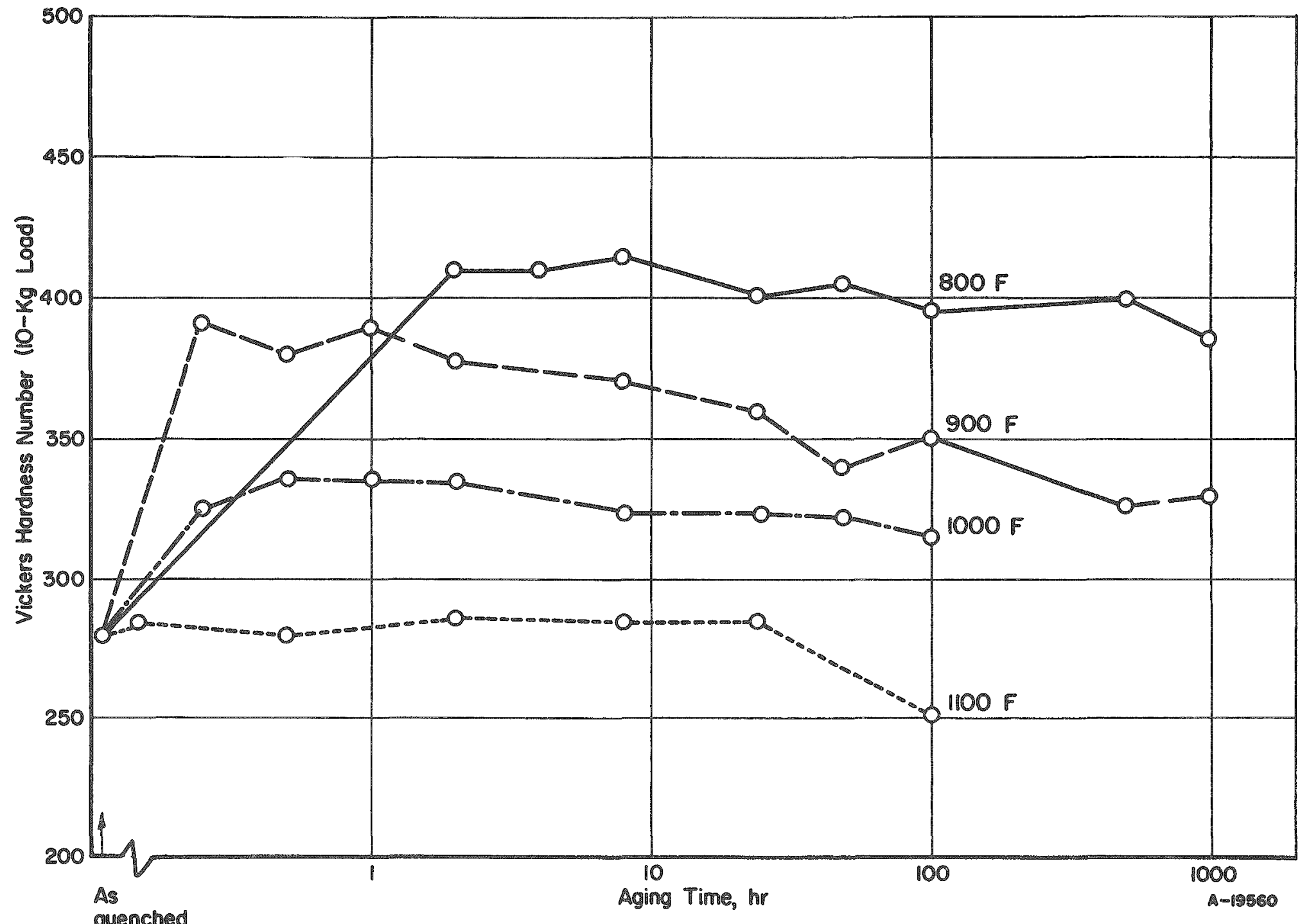

FIGURE A-1. AGE-HARDENING CHARACTERISTICS OF THE ZIRCONIUM-5 W/OMOLYBDENUM2 W/O TIN ALLOY QUENCHED FROM $1450 \mathrm{~F}$

Aging temperatures as indicated. 


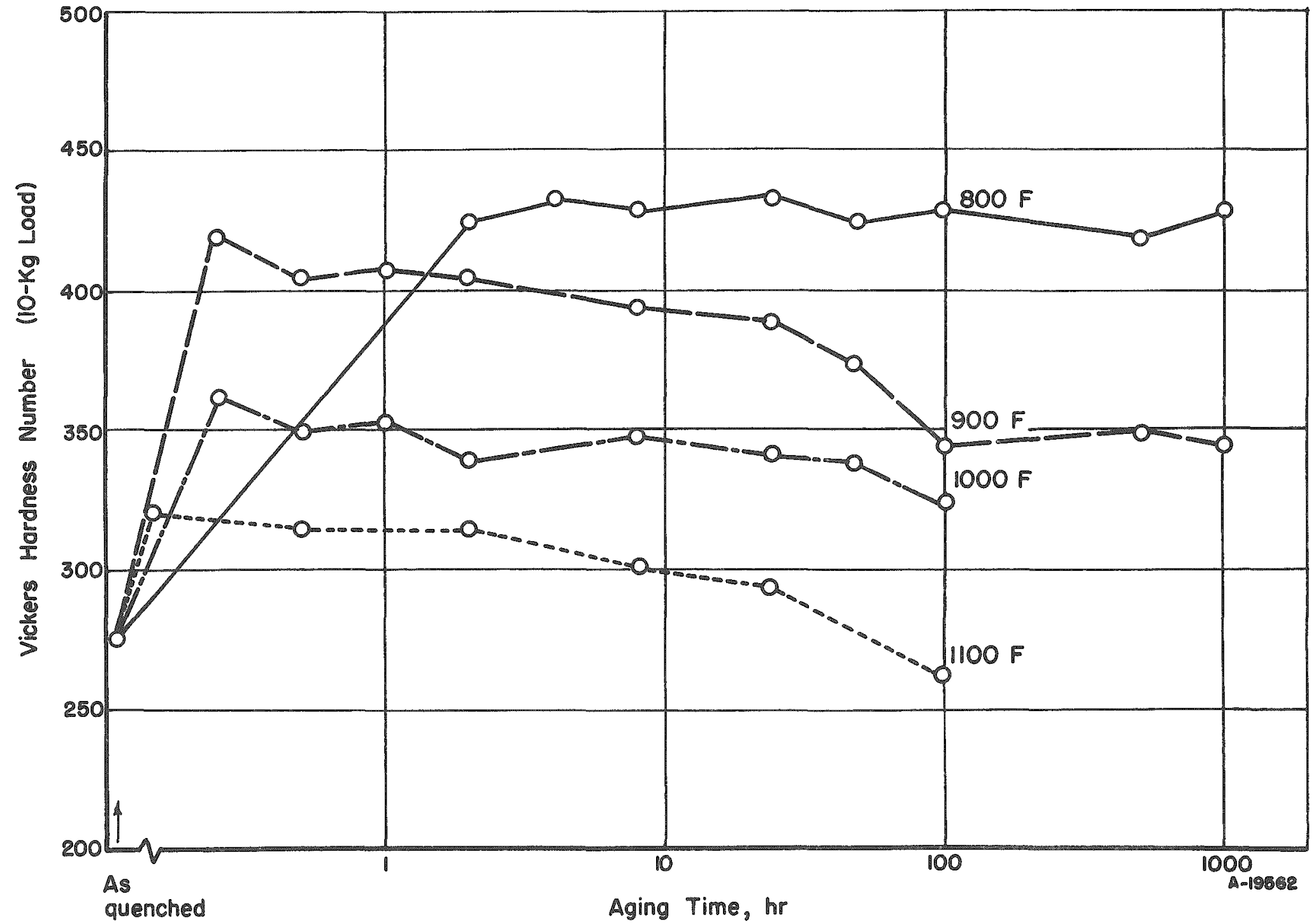

FIGURE A-2。AGE-HARDENING CHARACTERISTICS OF THE ZIRCONIUM- 5 w/0 MOLYBDENUM-2 w/o TIN ALLOY QUENCHED FROM $1525 \mathrm{~F}$

Aging temperatures as indicated. 


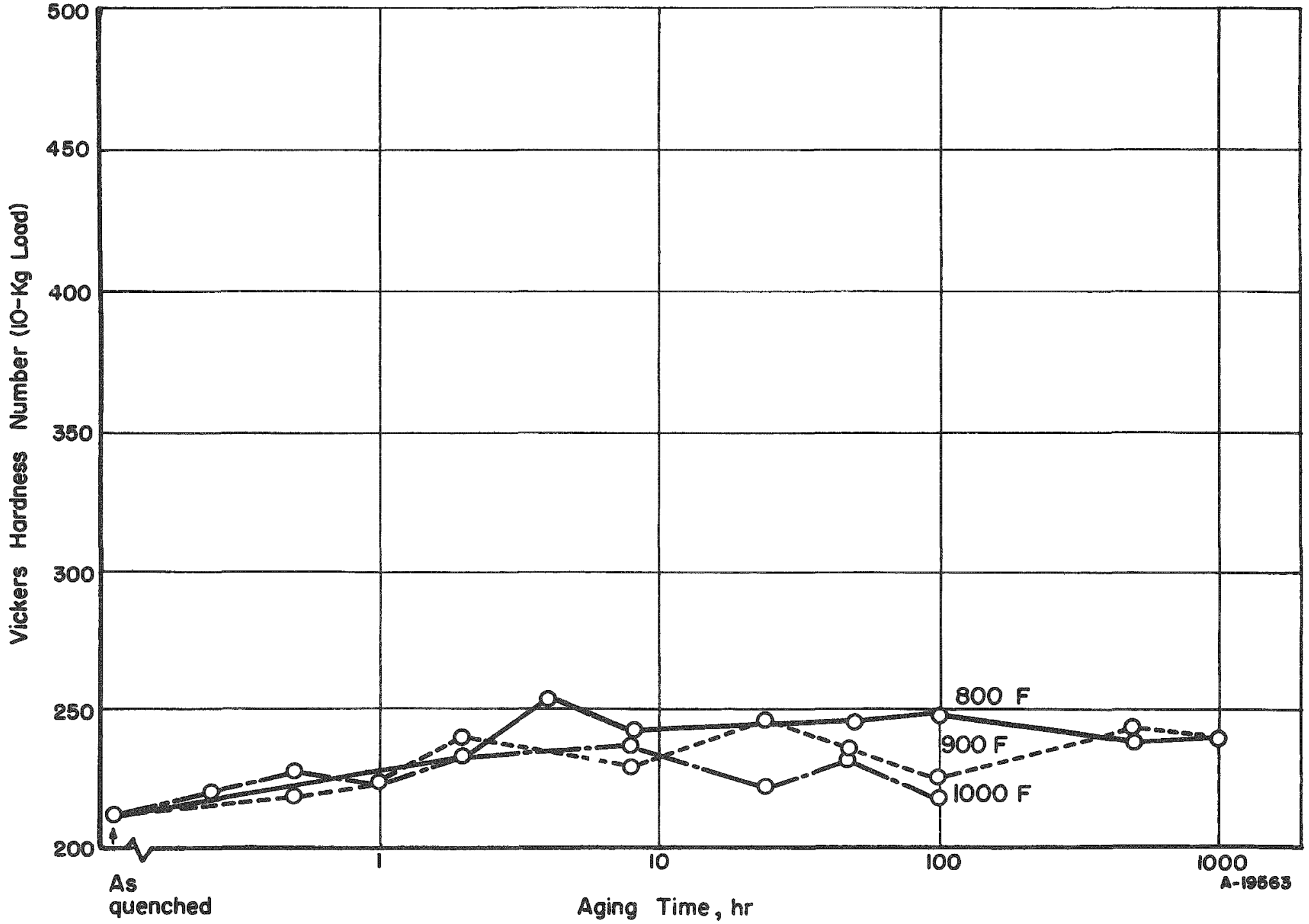

FIGURE A-3. AGE-HARDENING CHARACTERISTICS OF THE ZIRCONIUM-5 w/o NIOBIUM-2 w/0 TIN ALLOY QUENCHED FROM $1150 \mathrm{~F}$

Aging temperatures as indicated. 


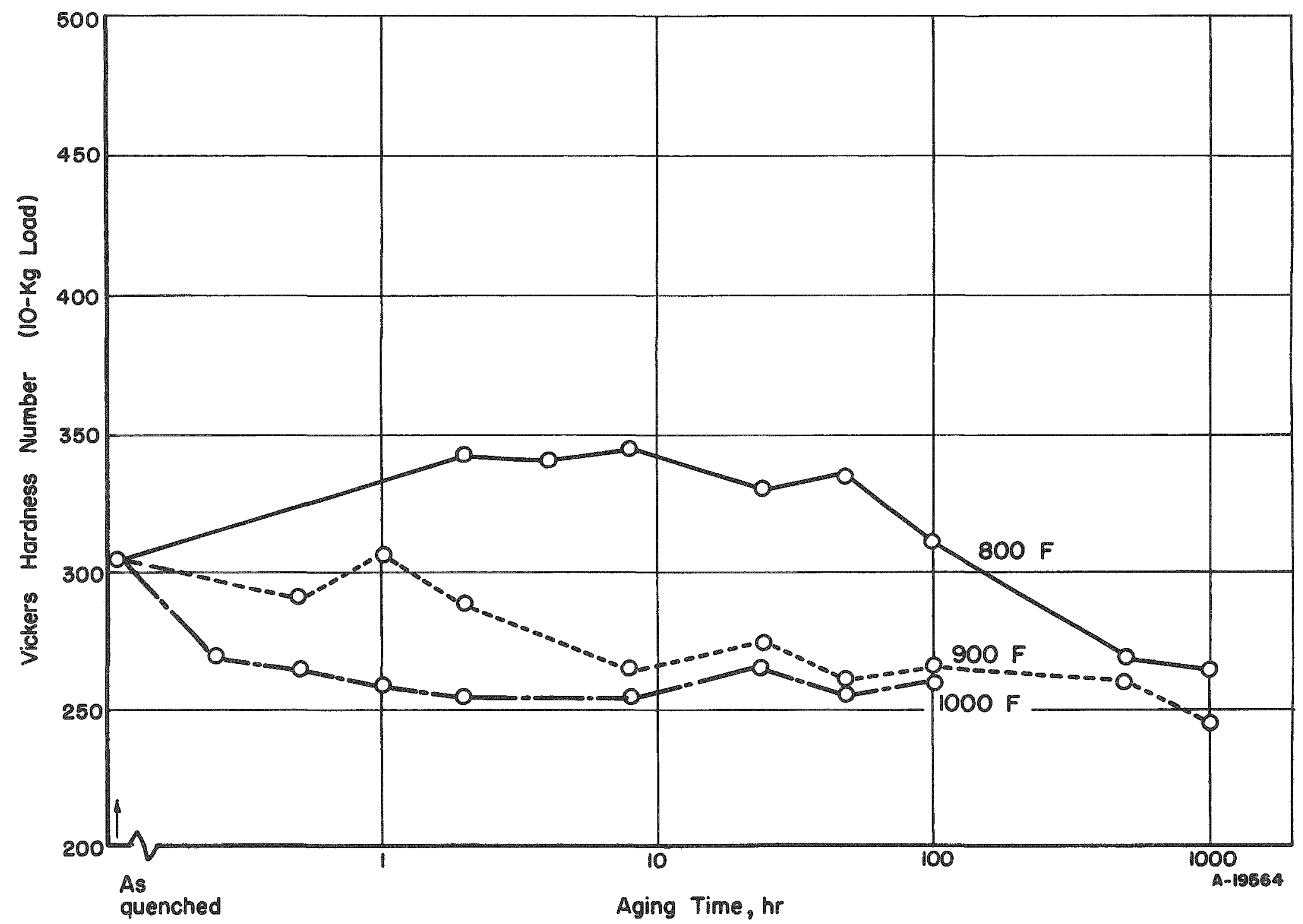

FIGURE A-4. AGE-HARDENING CHARACTERISTICS OF THE ZIRCONIUM-5 w/o NIOBIUM-2 w/0 TIN ALLOY QUENCHED FROM $1375 \mathrm{~F}$

Aging temperatures as indicated. 


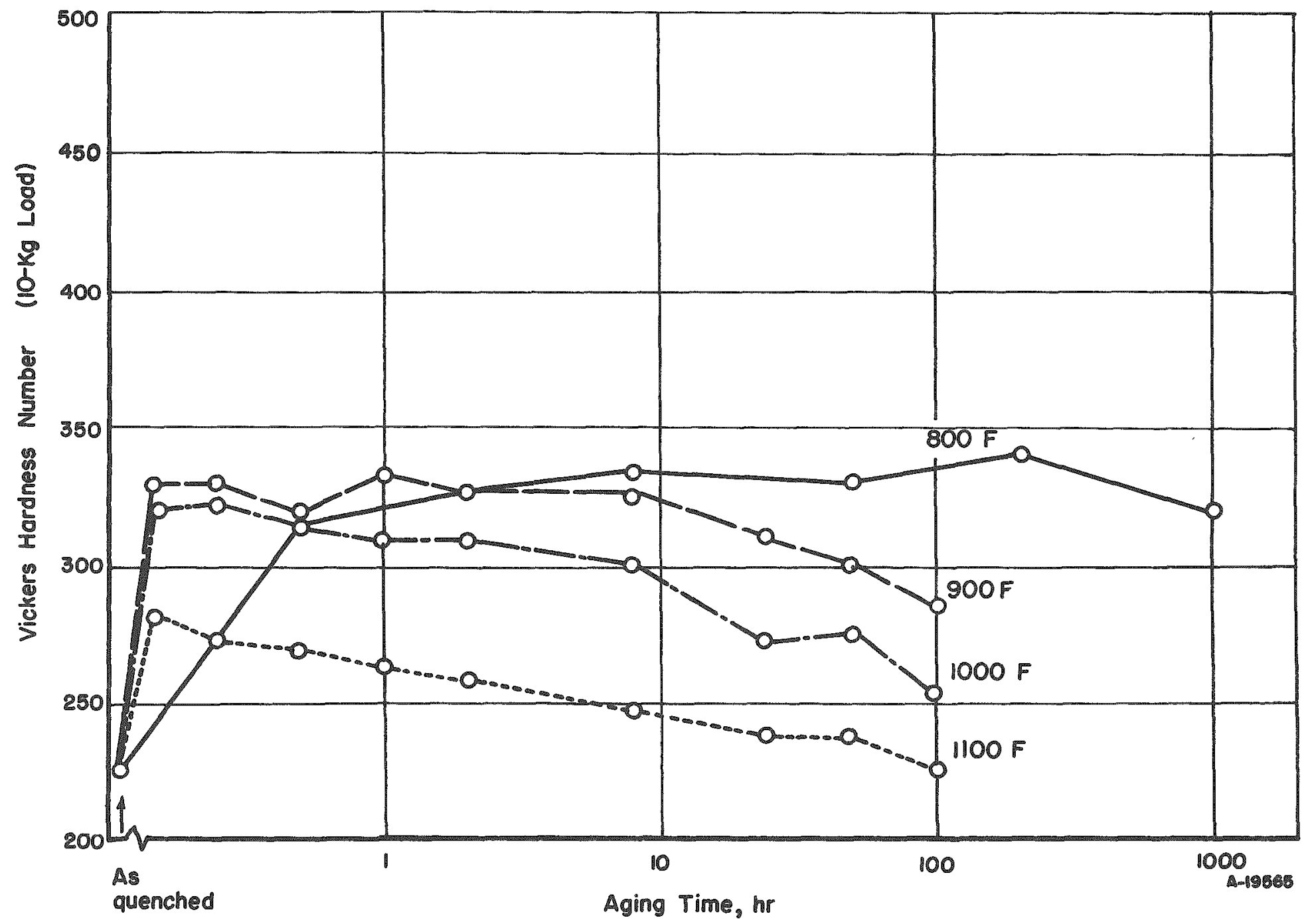

FIGURE A-5. AGE-HARDENING CHARACTERISTICS OF THE ZIRCONIUM-5 w/0 NIOBIUM-2 w/0 TIN ALLOY QUENCHED FROM $1450 \mathrm{~F}$

Aging temperatures as indicated. 


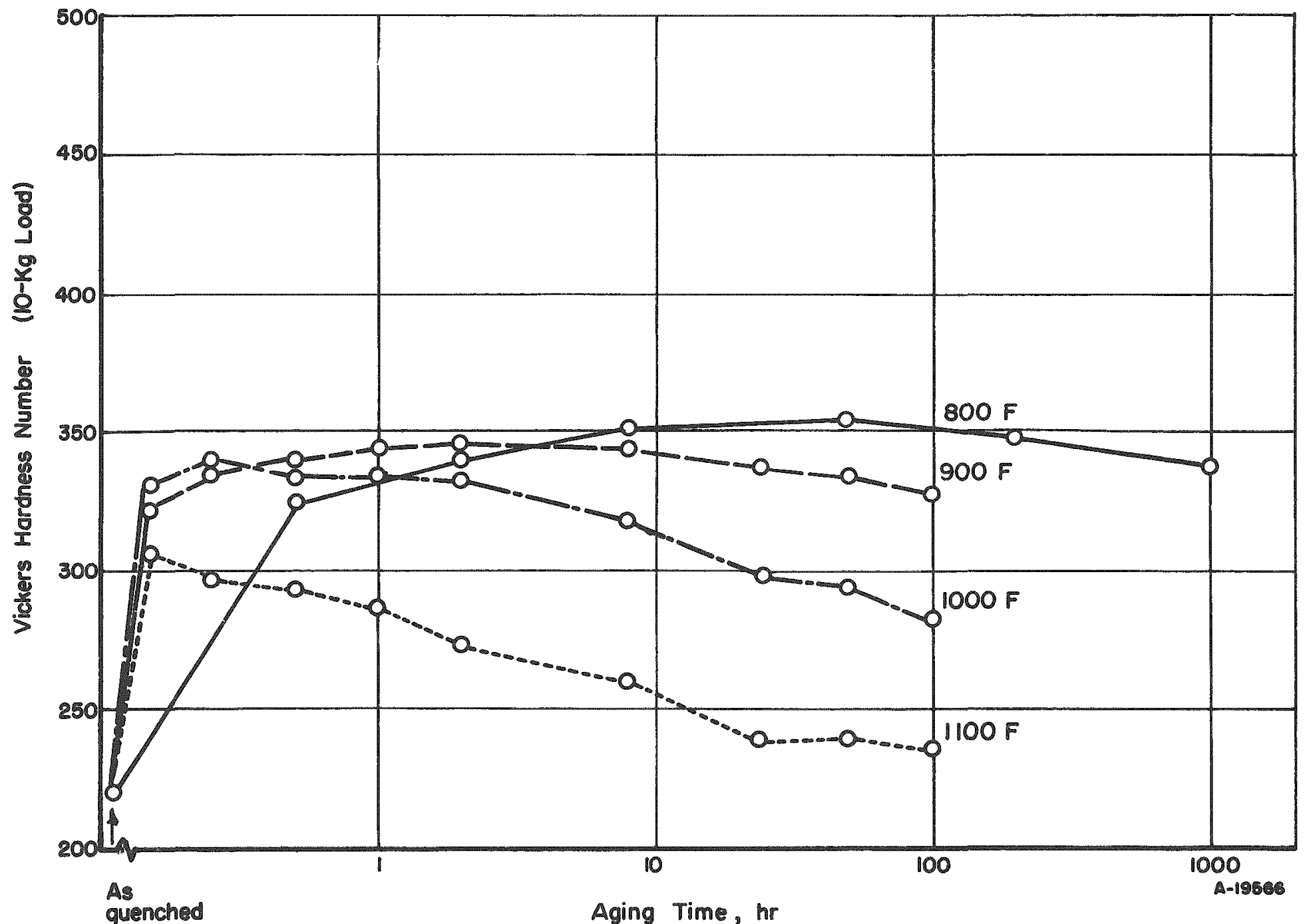

FIGURE A-6. AGE-HARDENING CHARACTERISTICS OF THE ZIRCONIUM-5 w/o NIOBIUM-2 w/o TIN ALLOY QUENCHED FROM 1525 F

Aging temperatures as indicated. 


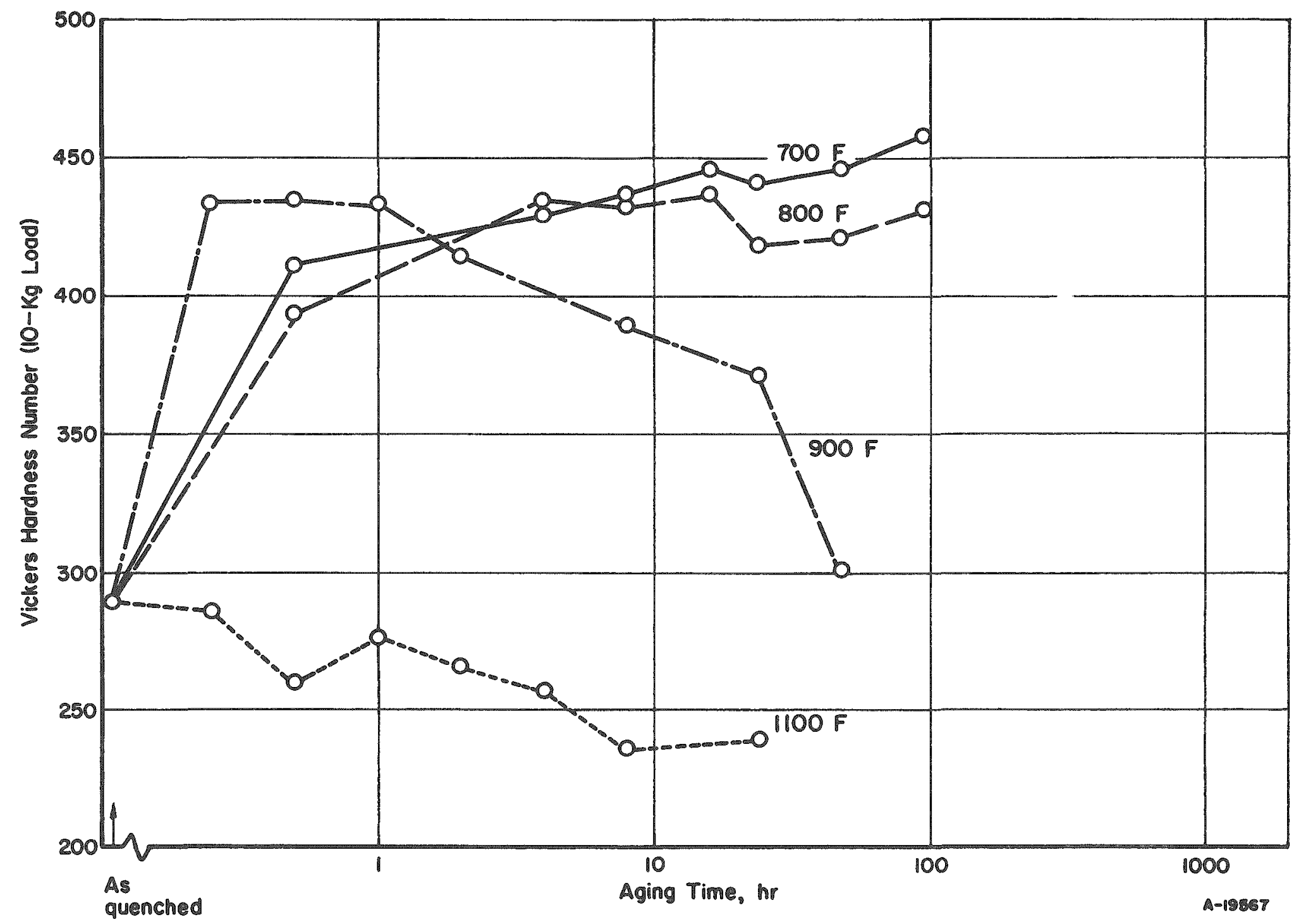

FIGURE A-7. AGE-HARDENING CHARAC TERISTICS OF THE ZIRCONIUM-5.5 w/O MOLYBDENUM ALLOY QUENCHED FROM $1435 \mathrm{~F}$

Aging temperatures as indicated. 


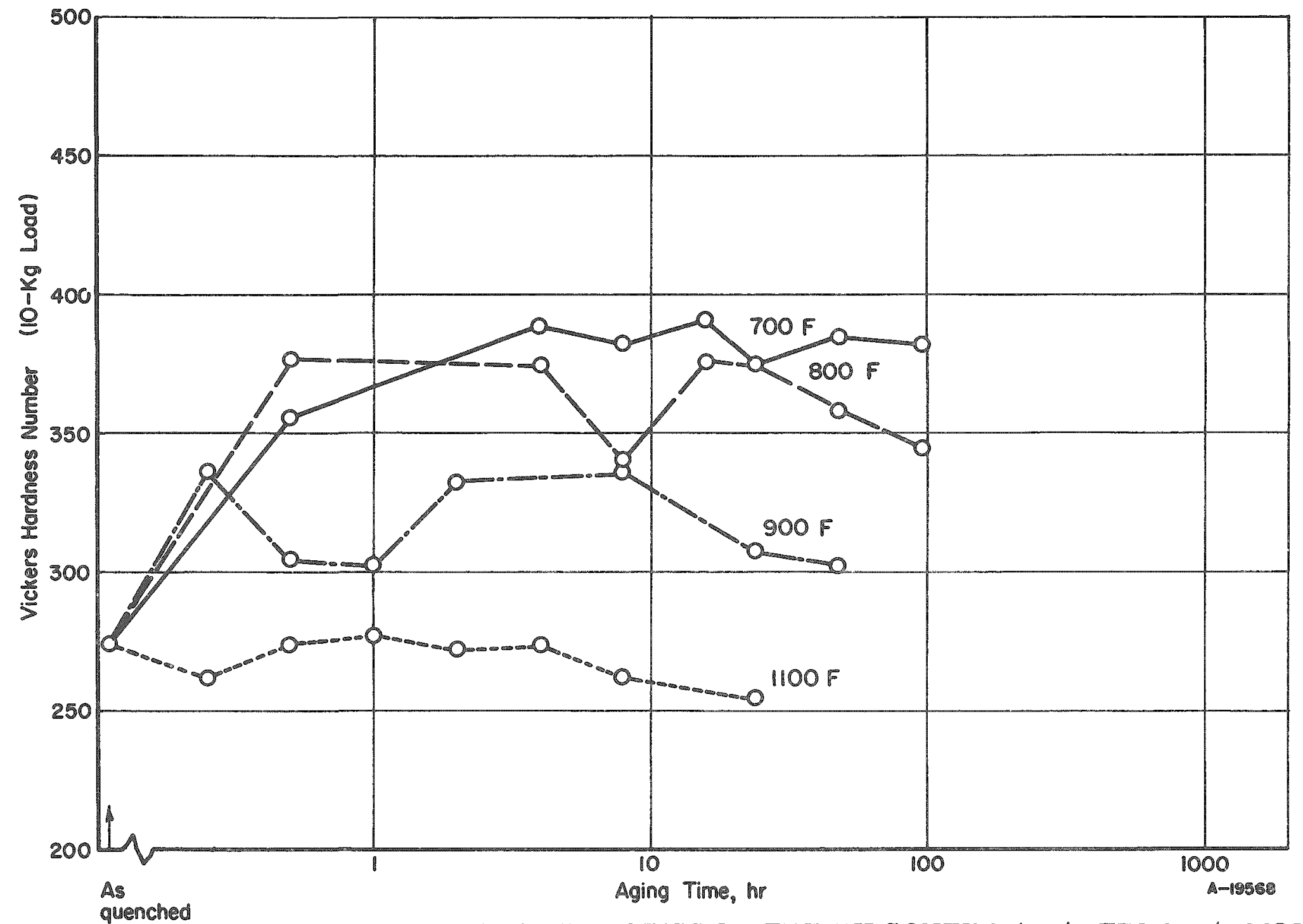

FIGURE A-8. AGE-HARDENING CHARAC TERISTICS OF THE ZIRCONIUM-4 w/0 TIN-2 w/0 MOLYBDENUM ALLOY QUENCHED FROM $1580 \mathrm{~F}$

Aging temperatures as indicated. 


\section{APPENDIX B}

TABLES OF HEAT-TREATMENT AND MECHANICALPROPERTY DATA 
TABLE B-1. TENSILE PROPERTIES AND HARDNESS OF HEAT-TREATED ALPHA-BETA ZIRCONIUM ALLOYS

\begin{tabular}{|c|c|c|c|c|c|c|c|c|c|c|}
\hline \multirow[b]{2}{*}{ Heat } & \multirow{2}{*}{$\begin{array}{c}\text { Nominal Composition } \\
\text { (Balance Zirconium), } \\
\text { w/o }\end{array}$} & \multirow{2}{*}{$\begin{array}{c}\text { Solution } \\
\text { Temperature(a) } \\
\text { F }\end{array}$} & \multicolumn{2}{|c|}{ Aging Data(b) } & \multirow[b]{2}{*}{$\begin{array}{c}\text { Orientation of } \\
\text { Specimens }(c)\end{array}$} & \multicolumn{2}{|c|}{ Elongation (d) } & \multirow{2}{*}{$\begin{array}{l}0.2 \text { Per Cent Offser } \\
\text { Yield Strength(d), } \\
\text { psi }\end{array}$} & \multirow{2}{*}{$\begin{array}{l}\text { Ultimate Tensile } \\
\text { Strength }(\mathrm{d}), \\
\text { psi }\end{array}$} & \multirow{2}{*}{$\begin{array}{l}\text { VHIN } \\
(10-16 \mathrm{~g} \\
\text { Load (e) } \\
\end{array}$} \\
\hline & & & $\begin{array}{c}\text { Time, } \\
\text { hr }\end{array}$ & $\begin{array}{c}\text { Temperature, } \\
\text { F } \\
\end{array}$ & & $\begin{array}{c}\text { Per Cent } \\
\text { in } 1 \mathrm{In} .\end{array}$ & $\begin{array}{l}\text { Per Cent } \\
\text { in } 2 \text { In. }\end{array}$ & & & \\
\hline \multirow[t]{4}{*}{$x-11$} & $5.5 \mathrm{Mo}$ & 1435 & 48 & 700 & $\mathrm{~L}$ & $-\infty$ & $0.5^{(f)}$ & $-\infty$ & 77.000 & $\cdots$ \\
\hline & & 1435 & 24 & 900 & $\mathfrak{L}$ & - & $1.5(\mathfrak{f})$ & $-\infty$ & 160,500 & $-\infty$ \\
\hline & & 1435 & 8 & 1000 & $\mathrm{~L}$ & - & 0.5 & 103,000 & 108,500 & $-\infty$ \\
\hline & & 1525 & 24 & 900 & L & $-\infty$ & 1.0 & - & 109,000 & $-\infty$ \\
\hline \multirow[t]{6}{*}{$A-4$} & $5 \mathrm{MO}-2 \mathrm{Sn}$ & 1525 & - & -- & $\mathbf{L}$ & - & 2.0 & $150,000(\mathrm{f})$ & $156,000(f)$ & 283 \\
\hline & & 1525 & 48 & 800 & $\mathrm{~L}$ & $-\infty$ & $\infty$ & -- & 145,000 & $42 j$ \\
\hline & & 1525 & 24 & 900 & $\mathbb{L}$ & $=$ & 1.5 & 197,000 & 203,000 & 364 \\
\hline & & 1525 & 8 & 1000 & $\mathbf{L}$ & - & 0.5 & 172,000 & 179,000 & 33.3 \\
\hline & & 1525 & 4 & 1100 & $\mathbf{L}$ & -- & - & 145,500 & 151.500 & 293 \\
\hline & & 1785 & 4 & 1100 & $\mathbf{L}$ & $-\infty$ & $1.0(f)$ & $169,000(\mathrm{f})$ & $169_{3} 500(f)$ & 341 \\
\hline \multirow[t]{11}{*}{$C-49$} & $5 \mathrm{Mo}-2 \mathrm{Sn}$ & 1525 & $-\infty$ & $-\infty$ & L & $10.0(f)$ & $-\infty$ & 113,000 & 153,000 & $-\infty$ \\
\hline & & 1525 & $\cdots$ & $\infty$ & $\mathrm{T}$ & 7.5 & -- & 145,000 & 163,000 & $\infty$ \\
\hline & & 1525 & 48 & 900 & $L$ & 11.5 & $-\infty$ & 153,500 & 168,500 & $\infty$ \\
\hline & & 1525 & 2 & 1000 & $\mathbb{L}$ & 3.5 & $\infty=\infty$ & 150,000 & 164,500 & $\cdots$ \\
\hline & & 1525 & 8 & 1000 & $L$ & 2.5 & $-\infty$ & 149,000 & 161,000 & $-\infty$ \\
\hline & & 1525 & 8 & 1000 & $\mathrm{~T}$ & $1.0(f)$ & $\cdots$ & 166,500 & 172,500 & $-\infty$ \\
\hline & & 1525 & 24 & 1000 & $\mathrm{~L}$ & 3.5 & $\infty$ & 140,500 & 154,000 & $-\infty$ \\
\hline & & 1525 & 48 & 1000 & $\mathrm{~L}$ & 2.5 & - & 140,000 & 151.500 & $-\infty$ \\
\hline & & 1525 & 48 & 1000 & $T$ & 2.0 & -- & 152,000 & 160,500 & $\infty$ \\
\hline & & 1525 & 2 & 1100 & $\mathcal{L}$ & 2.0 & - & 128,500 & 141,000 & $\infty$ \\
\hline & & 1525 & 2 & 1100 & $\mathrm{~T}$ & $2.0(f)$ & -- & 144,000 & 150,500 & $-\infty$ \\
\hline
\end{tabular}


TABLE B -1. (Continued)

\begin{tabular}{|c|c|c|c|c|c|c|c|c|c|c|}
\hline \multirow[b]{2}{*}{ Heat } & \multirow{2}{*}{$\begin{array}{c}\text { Nominal Composition } \\
\text { (Balance Zirconium). } \\
\text { W/o } \\
\end{array}$} & \multirow{2}{*}{$\begin{array}{c}\text { Solution } \\
\text { Temperature(a), } \\
\text { F }\end{array}$} & \multicolumn{2}{|c|}{ Aging Data(b) } & \multirow[b]{2}{*}{$\begin{array}{l}\text { Orientation of } \\
\text { Specimens }(c)\end{array}$} & \multicolumn{2}{|c|}{ Elongation(d) } & \multirow{2}{*}{$\begin{array}{l}0.2 \text { Per Cent Offset } \\
\text { Yield Strength(d), } \\
\text { psi }\end{array}$} & \multirow{2}{*}{$\begin{array}{l}\text { Ultimate Tensile } \\
\text { Strength(d), } \\
\text { psi }\end{array}$} & \multirow{2}{*}{$\begin{array}{c}\text { VHN } \\
\left(10-K_{g}\right. \\
\text { Load) }(\mathrm{e})\end{array}$} \\
\hline & & & $\begin{array}{c}\text { Time, } \\
\mathrm{hr}\end{array}$ & $\begin{array}{c}\text { Temperature, } \\
F\end{array}$ & & $\begin{array}{l}\text { Per Cent } \\
\text { in } 1 \mathrm{I} \Omega_{\text {. }}\end{array}$ & $\begin{array}{l}\text { Per Cent } \\
\text { in } 2 \text { In. }\end{array}$ & & & \\
\hline \multirow[t]{6}{*}{$A-6$} & $5 N b-2 S n$ & 1525 & $\cdots$ & -- & $L$ & - & $0.5^{(f)}$ & 162.500 & 168,500 & 344 \\
\hline & & 1525 & 48 & 800 & $L$ & -- & $3.5(f)$ & $-\infty$ & $209_{8}, 000$ & 419 \\
\hline & & 1525 & 24 & 900 & L & - & 8.5 & 155,000 & 170,000 & 378 \\
\hline & & 1525 & 8 & 1000 & $L$ & - & 10.5 & 150,000 & 160,000 & 350 \\
\hline & & 1525 & 4 & 1100 & $\mathrm{~L}$ & - & 9.0 & 142,000 & 148,500 & 309 \\
\hline & & 1785 & 4 & 1100 & $L$ & - & 4.5 & 155,500 & 163,500 & 352 \\
\hline \multirow[t]{21}{*}{$B-2$} & $5 \mathrm{Nb}-2 \mathrm{Sn}$ & 1450 & -- & -- & $\mathrm{L}$ & $13.0^{(f)}$ & -- & 87.500 & 114,000 & 306 \\
\hline & & 1450 & $1 / 2$ & 900 & $\mathrm{~L}$ & $1.0(g)$ & -- & 136,000 & 156,500 & 333 \\
\hline & & 1450 & 8 & 900 & $\mathrm{~L}$ & $7.5^{(f)}$ & - & 121,500 & 152,000 & 285 \\
\hline & & 1450 & 48 & 900 & $L$ & $2.0(g)$ & $-\infty$ & 109,500 & $145_{8} 000$ (h) & 283 \\
\hline & & 1525 & -- & -- & $L$ & 13.0 & -- & 67,000 & 106,000 & 211 \\
\hline & & 1525 & -- & -- & $\mathrm{T}$ & 8.0 & -- & $76,500^{(i)}$ & 114,000 & -- \\
\hline & & 1525 & $1 / 2$ & 900 & $\mathrm{~L}$ & $1.0(\mathrm{~g})$ & $-\infty$ & 158,500 & 172,000 & 349 \\
\hline & & 1525 & 8 & 900 & $\mathrm{~L}$ & 0.5 & -- & $155,000(\mathrm{~J})$ & $177,000(3)$ & 348 \\
\hline & & 1525 & 8 & 900 & $\mathrm{~T}$ & $1.0(\mathrm{~g})$ & -- & 167.500 & 174,000 & - \\
\hline & & 1525 & 24 & 900 & $\mathrm{~L}$ & $7.0^{(f)}$ & -- & 149,500 & 170,000 & -- \\
\hline & & 1525 & 48 & 900 & $L$ & 3.0 & -- & 146,500 & 171.000 & 318 \\
\hline & & 1525 & $1 / 2$ & 1000 & $L$ & $4_{\bullet} 0(f)$ & - & 159,500 & 177,500 & 330 \\
\hline & & 1525 & 2 & 1000 & L & 2.0 & -- & 142,500 & 167,000 & 322 \\
\hline & & 1525 & 8 & 1000 & $\mathrm{~L}$ & 10.0 & - & 133,000 & 153,000 & -- \\
\hline & & 1525 & $24^{(k)}$ & 1000 & L & 8.5 & -- & 117,000 & 143,500 & 297 \\
\hline & & 1525 & $1 / 2$ & 1100 & $\mathrm{~L}$ & 5.0 & -- & 125,500 & 144,500 & 297 \\
\hline & & 1525 & $24^{(k)}$ & 1100 & $\mathrm{~L}$ & $16.0^{(f)}$ & -- & 96,000 & 112,500 & 259 \\
\hline & & 1600 & - & -. & $L$ & 17.0 & -- & 78,000 & 114,000 & 218 \\
\hline & & 1600 & -- & -- & $\mathrm{T}$ & 15.0 & -- & $72,000(1)$ & 113,500 & -- \\
\hline & & 1600 & $1 / 2$ & 900 & $\mathrm{~L}$ & 1.5 & -- & 165,500 & 177.000 & 340 \\
\hline & & 1600 & 8 & 900 & $L$ & 2.0 & - & 178,000 & 190,500 & 351 \\
\hline
\end{tabular}


TABLE B-1. (Continued)

\begin{tabular}{|c|c|c|c|c|c|c|c|c|c|c|}
\hline \multirow[b]{2}{*}{ Heat } & \multirow{2}{*}{$\begin{array}{c}\text { Nominal Composition } \\
\text { (Balance Zirconium), } \\
\text { w/o }\end{array}$} & \multirow{2}{*}{$\begin{array}{l}\text { Solution } \\
\text { Temperature(a), } \\
F\end{array}$} & \multicolumn{2}{|c|}{ Aging Data(b) } & \multirow[b]{2}{*}{$\begin{array}{l}\text { Orientation of } \\
\text { Specimens }(c)\end{array}$} & \multicolumn{2}{|c|}{ Elongation(d) } & \multirow{2}{*}{$\begin{array}{l}0.2 \text { Per Cent Offset } \\
\text { Yield Strength }(d) \\
\text { psi }\end{array}$} & \multirow{2}{*}{$\begin{array}{l}\text { Ultimate Tensile } \\
\text { Strength (d) } \\
\text { psi }\end{array}$} & \multirow{2}{*}{$\begin{array}{r}\text { VHN } \\
(10-5 . g \\
\left.\text { Load }^{10}\right)\end{array}$} \\
\hline & & & $\begin{array}{c}\text { Time, } \\
\text { hr }\end{array}$ & $\begin{array}{c}\text { Temperature, } \\
\text { F }\end{array}$ & & $\begin{array}{l}\text { Per Cent } \\
\text { in } 1 \mathrm{In} .\end{array}$ & $\begin{array}{l}\text { Per Cent } \\
\text { in } 2 \mathrm{In} .\end{array}$ & & & \\
\hline & & 1600 & 8 & 900 & $\mathrm{~T}$ & $1.5(g)$ & $-\infty$ & 176,000 & 187,000 & $\infty$ \\
\hline & & 1600 & 24 & 900 & $\mathrm{~L}$ & 3.0 & -- & 162,000 & 177.500 & -- \\
\hline & & 1600 & 24 & 900 & $T$ & 4.5 & -- & 172,000 & 187,500 & $-\infty$ \\
\hline & & 1600 & 48 & 900 & $L$ & 2.5 & -- & 166,000 & 183,500 & $34 \varepsilon$ \\
\hline & & 1600 & $1 / 2$ & 1000 & $L$ & 2.5 & $-\infty$ & 173,000 & 184.000 & 336 \\
\hline & & 1600 & 2 & 1000 & $L$ & 2.5 & -- & 167.000 & 181,000 & $33 \varepsilon$ \\
\hline & & 1600 & 8 & 1000 & $\mathrm{~L}$ & $14.0^{(\mathrm{f})}$ & - & 153,500 & 168,000 & -- \\
\hline & & 1600 & $24(k)$ & 1000 & $L$ & $2.5(g)$ & $-\infty$ & 140,500 & 156,000 & 309 \\
\hline
\end{tabular}

(a) Held $1 / 2$ hr at temperature in a helium atmosphere and quenched into cold water.

(b) Quenched into cold water from aging temperature.

(c) Specimen axis parallel to final rolling direction (L); or perpendicular (T).

(d) Average of two values except where noted.

(e) Average of three impressions.

(f) Single value.

(g) Average of uniform elongation, specimens broke in or outside of gage marks.

(h) Values of 152,000 and 137,500 psi were obtained.

(i) Values of 83,500 and 69,500 were obtained.

(j) Values of 148,500 and 161,000 psi yield strength and 172,000 and 181,500 psi ultimate were obtained.

(k) Aged in helium atmosphere and quenched.

(1) Values of 63,500 and 80,500 psi were obtained. 
TABLE B-2. TENSILE PROPERTIES AND HARDNESS OF HEAT-TREATED ALPHA ZRCONIUMI ALLOYS

\begin{tabular}{|c|c|c|c|c|c|c|c|c|}
\hline \multirow[b]{2}{*}{ Heat } & \multirow{2}{*}{$\begin{array}{c}\text { Nominal Composition } \\
\text { (Balance Zirconium), } \\
\text { W/o }\end{array}$} & \multirow{2}{*}{$\begin{array}{c}\text { Solution } \\
\text { Temperature(a) } \\
\text { F } \\
\end{array}$} & \multicolumn{2}{|c|}{ Aging Data(b) } & \multirow[b]{2}{*}{$\begin{array}{c}\text { Elongation in } \\
2 \mathrm{In}_{\circ}^{(\mathrm{c})}, \text { per cent }\end{array}$} & \multirow{2}{*}{$\begin{array}{l}0.2 \text { Per Cent Offset } \\
\text { Yield Strength(c). } \\
\text { psi }\end{array}$} & \multirow{2}{*}{$\begin{array}{c}\text { Ultimate Tensile } \\
\text { Strength(c) } \\
\text { psi }\end{array}$} & \multirow{2}{*}{$\begin{array}{c}\text { VHN } \\
(10-\mathrm{Kg} \\
\text { Load)(d) }\end{array}$} \\
\hline & & & $\begin{array}{c}\text { Time, } \\
\text { hr }\end{array}$ & $\begin{array}{c}\text { Temperature, } \\
\text { F } \\
\end{array}$ & & & & \\
\hline \multirow[t]{6}{*}{$A=2$} & $1.5 \mathrm{Sn}=0.1 \mathrm{Cr}-$ & 1580 & -- & -- & 17.5 & 82,500 & 95,500 & 239 \\
\hline & $0.12 \mathrm{Fe}-0.005 \mathrm{Ni}$ & 1580 & 48 & 800 & 20.0 & 91,000 & 100,500 & 242 \\
\hline & (Zircaloy 2) & 1580 & 24 & 900 & 18.5 & 89.000 & 99,000 & 246 \\
\hline & & 1580 & 8 & 1000 & 19.0 & 88,500 & 98,000 & 242 \\
\hline & & 1580 & 4 & 1100 & $19.5(\mathrm{e})$ & $84.500(e)$ & $95,000(e)$ & 241 \\
\hline & & 1885 & 4 & 1100 & 8.5 & 101,500 & 119,500 & 292 \\
\hline \multirow[t]{5}{*}{$A-3$} & $2 \mathrm{Sn}-2 \mathrm{MO}$ & 1580 & $-\infty$ & -- & 1.5 & $109_{3} 500$ & 135,500 & 308 \\
\hline & & 1580 & 48 & 800 & 0.5 & 158,000 & 123,000 & 351 \\
\hline & & 1580 & 8 & 1000 & 8.3 & 123,000 & 138,500 & 306 \\
\hline & & 1580 & 4 & 1100 & $10.0^{(e)}$ & 114,500 & 131,000 & 275 \\
\hline & & 1885 & 4 & 1100 & $0^{(e)}$ & $142.500(\mathrm{e})$ & $150,500(\mathrm{e})$ & 335 \\
\hline \multirow[t]{4}{*}{$T M-42$} & $4 \mathrm{Sn}-2 \mathrm{Mo}$ & 1580 & 48 & 700 & $1.0(e)$ & $142,000(\mathrm{e})$ & $185,500(\mathrm{e})$ & - \\
\hline & & 1580 & 24 & 900 & 6.3 & $106,000(\mathrm{e})$ & $140,500(\mathrm{c})$ & - \\
\hline & & 1580 & 8 & 1100 & 7.5 & $100,500^{(e)}$ & 126,000 & $-\infty$ \\
\hline & & 1785 & 24 & 900 & 0.5 & -- & $144_{2} 000(e)$ & - \\
\hline \multirow[t]{6}{*}{$A-8$} & $4 \mathrm{Sn}-1 \mathrm{Mo}-$ & 1580 & -- & -- & 2.8 & 115,000 & 136,500 & 295 \\
\hline & $0.5 \mathrm{Cr}-0.25 \mathrm{Ni}$ & 1580 & 48 & 800 & 5.0 & 113,000 & 137,500 & 301 \\
\hline & & 1580 & 24 & 900 & 12.5 & 109,500 & 124,500 & 269 \\
\hline & & 1580 & 8 & 1000 & 4.0 & 106,500 & 123,000 & 265 \\
\hline & & 1580 & 4 & 1100 & $9.5^{(e)}$ & 105,000 & 116,000 & 256 \\
\hline & & 1885 & 4 & 1100 & 0.5 & - & $156,500(\mathrm{e})$ & 340 \\
\hline
\end{tabular}

(a) Held $1 / 2 \mathrm{hr}$ at temperature in a helium atmosphere and quenched into cold water.

(b) Quenched into cold water from aging temperature.

(c) Average of two values except where noted.

(d) Average of three impressions.

(e) Single value. 